\title{
Involvement of adenosine A1 receptors in systemic inflammation and altered vascular reactivity in allergic mice
}

Dovenia S. Ponnoth

West Virginia University

Follow this and additional works at: https://researchrepository.wvu.edu/etd

\section{Recommended Citation}

Ponnoth, Dovenia S., "Involvement of adenosine A1 receptors in systemic inflammation and altered vascular reactivity in allergic mice" (2008). Graduate Theses, Dissertations, and Problem Reports. 4416. https://researchrepository.wvu.edu/etd/4416

This Dissertation is protected by copyright and/or related rights. It has been brought to you by the The Research Repository @ WVU with permission from the rights-holder(s). You are free to use this Dissertation in any way that is permitted by the copyright and related rights legislation that applies to your use. For other uses you must obtain permission from the rights-holder(s) directly, unless additional rights are indicated by a Creative Commons license in the record and/ or on the work itself. This Dissertation has been accepted for inclusion in WVU Graduate Theses, Dissertations, and Problem Reports collection by an authorized administrator of The Research Repository @ WVU.

For more information, please contact researchrepository@mail.wvu.edu. 
Involvement of Adenosine $A_{1}$ receptors in systemic inflammation and altered vascular reactivity in allergic mice

Dovenia S. Ponnoth

Dissertation submitted to the School of Pharmacy at West Virginia University in partial fulfillment of the requirements for the degree of

Doctor of Philosophy

in

Pharmaceutical and Pharmacological Sciences

S. Jamal Mustafa, Ph. D., Chair

Matthew Boegehold, Ph. D.

Patrick Callery, Ph. D.

Vincent Castranova, Ph. D.

Jeffrey Fedan, Ph. D.

Morgantown, West Virginia

2008

Keywords: Asthma, adenosine, adenosine receptor, inflammation, vascular reactivity

Copyright 2008 Dovenia S. Ponnoth 


\title{
ABSTRACT \\ Involvement of Adenosine $A_{1}$ receptors in systemic inflammation and altered vascular reactivity in allergic mice
}

\author{
Dovenia S. Ponnoth
}

Epidemiological studies have established that people who have lung diseases such as asthma and COPD are likely to develop adverse cardiovascular events. While the reason for this has not been elucidated, it is believed that inflammation could be the key component linking the two conditions. Adenosine, an endogenous purine nucleoside, has been strongly implicated in asthma pathophysiology and also has potent effects on the cardiovascular system. This work was undertaken to gain a better understanding of the relationship between asthma and its cardiovascular effects, and more specifically the possible role adenosine plays under these conditions.

We hypothesize that asthmatic lung inflammation translates into systemic inflammation and alters vascular responses where adenosine plays an important role. Therefore, this study investigated the effects of aerosolized adenosine, used to elevate lung adenosine levels, on vascular reactivity and inflammation in a well established mouse model of allergic asthma established in our lab. We found that allergic mice had poor vasorelaxation to adenosine and systemic inflammation, in addition to lung inflammation, and aerosolized adenosine exacerbated these effects. Data indicated a possible role for $A_{1}$ adenosine receptor (AR) in altered vascular reactivity and inflammation. Based on these findings, we next studied the effects of adenosine using genetically modified mice in which the $A_{1} A R$ gene was deleted $\left(A_{1} K O\right)$ and corresponding $\mathrm{A}_{1}$ wild-type $\left(\mathrm{A}_{1} \mathrm{WT}\right)$ mice, in which the $\mathrm{A}_{1}$ receptor was present.

Allergic $\mathrm{A}_{1} \mathrm{KO}$ mice had no systemic inflammation, and the adenosine-mediated vasorelaxation responses obtained were comparable to non-allergic mice. Aerosolized adenosine also did not have any effect in $\mathrm{A}_{1} \mathrm{KO}$ mice. On the other hand, allergic $\mathrm{A}_{1} \mathrm{WT}$ mice had lower aortic relaxation response to non-selective adenosine analog NECA, presence of significantly higher levels of inflammatory cytokines in plasma and higher airway responsiveness to NECA, compared to non-allergic $\mathrm{A}_{1} \mathrm{WT}$ controls and all groups of $\mathrm{A}_{1} \mathrm{KO}$ mice, with aerosolized adenosine exacerbating all these responses. From these data, it can be concluded that asthmatic mice had poor vascular responses and inflammation, possibly mediated through the $\mathrm{A}_{1} \mathrm{AR}$. 
To my parents, Mildred and Kumar, and sister, Deanne 


\section{ACKNOWLEDGEMENT}

I am indebted to a number of people in bringing this dissertation to fruition. I thank my mentor Dr. Jamal Mustafa for his continuous guidance, help and direction in my research. I am very grateful for his understanding, kindness and immense patience during the four years that I spent in his laboratory. Many thanks to my dissertation committee: Drs.Boegehold, Callery, Castranova, and Fedan for their advice, scientific expertise and guidance in helping me complete this thesis project.

I worked with wonderful people, past and present, in Dr. Mustafa’s lab. Each one of them has taught me something and helped me out at various points. Thank you: Drs. Habib, Nayeem, Nadeem and Teng; my fellow students EJ Young and especially Maryam Sharifi, who has been a most supportive friend, our lab technician, Kevin Roush; Peter Oldenburg, Dr. R Ray Morrison and Dr. Ming Fan, former lab members (East Carolina University) and Dr. Stephen Tilley, University of North Carolina. I thank the faculty, students and administrative staff from the Departments of Physiology and Basic Pharmaceutical Sciences. Thanks especially to Debbie Anderson, Vickie White, Debbie Beery and Claire Noel. I'd like to acknowledge Drs. Dar, Taylor, Barnes, and the faculty and staff from the Department of Pharmacology and Toxicology at East Carolina University. Thanks also to Darin Sujjavanich, my friend and fellow student.

I am very grateful to Chittam Thakore and Conolly D'Souza for all of their support and help; they've been there for me right from the start of this experience. I also express my gratitude to Tim Percy. Last, but certainly not the least, I thank my family my parents and sister, without whom none of this would have been possible. They have always been my strength and driving force; I could not have reached here without their 
love, sacrifices and constant encouragement in pursuing my goals and this belongs to them as much as it does to me. 


\section{TABLE OF CONTENTS}

Page

LIST OF TABLES......................................................

LIST OF FIGURES...............................................................

LIST OF ABBREVIATIONS...............................................

CHAPTER ONE: INTRODUCTION........................................1

Generation of adenosine and its metabolism............................1

Adenosine Receptors..............................................4

Asthma..............................................................4

Adenosine in asthma...............................................5

Reactive airway diseases and cardiovascular complications..............7

Animal models of asthma.........................................8

Murine models in asthma..........................................8

Purpose and project summary..................................10

CHAPTER TWO: MATERIALS AND METHODS.................................... 12

Mice............................................................

Animal sensitization protocol....................................12

In vitro organ bath.................................................14

Airway responsiveness..........................................15

CHAPTER THREE: ADENOSINE-MEDIATED ALTERATION OF VASCULAR REACTIVITY AND INFLAMMATION IN A MOUSE MODEL OF ASTHMA..18

Abstract.........................................................18

Introduction...................................................19 
Materials and Methods

Animals

Animal Sensitization

Preparation of isolated mouse aorta and isometric force

measurement.

Contraction/relaxation experiments.

Experimental protocol....

Real time RT-PCR: $A_{1}, A_{2 A}, A_{2 B}, A_{3} A R$ and eNOS genes

expression. .24

Assessment of systemic inflammation. .25

Multiplex cytokine assay .....................................26

C-reactive protein assay....................................26

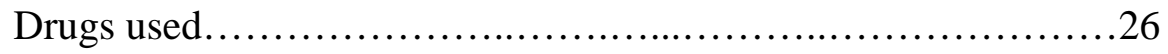

Statistical analysis.........................................27

Results.....................................................27

Systemic inflammation in control, allergic and adenosine aerosolized allergic mice. ...

Vascular reactivity in control, allergic and adenosine aerosolized

allergic mice. .28

Endothelial function and eNOS expression in control, allergic and adenosine aerosolized allergic mice. .29 Adenosine receptors gene expression in control, allergic and adenosine aerosolized allergic mice .30 
Effect of specific A1 AR (DPCPX) and A2B AR (alloxazine) antagonists on vascular reactivity in control, allergic and adenosine aerosolized allergic mice .......................................30

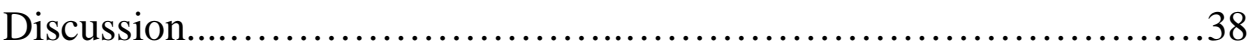

CHAPTER FOUR: ROLE OF $\mathrm{A}_{2 \mathrm{~A}}$ ADENOSINE RECEPTORS IN THE

REGULATION OF VASCULAR TONE.........................................................4

Abstract....................................................................44

Introduction.......................................................... 45

Materials and Methods...............................................47

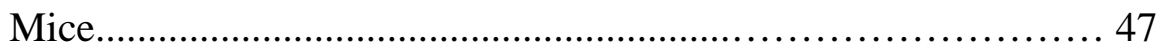

Preparation of isolated mouse aorta and isometric force

measurement..................................................... 47

Contraction/relaxation experiments........................................48

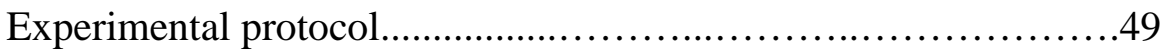

Real time PCR: $A_{1}, A_{2 A}, A_{2 B}$ and $A_{3}$ AR genes expression............49

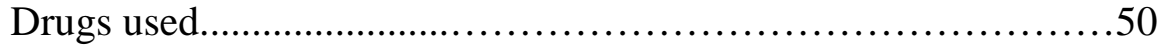

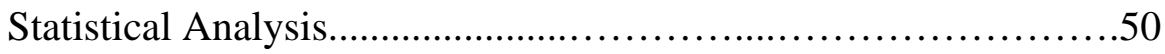

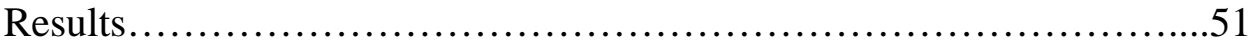

Response to NECA, CGS-21860 and BAY 60-6583.................51

Endothelial function in $\mathrm{A}_{2 \mathrm{~A}} \mathrm{WT}$ and $\mathrm{KO}$ aorta......................51

Adenosine receptors gene expression in $\mathrm{A}_{2 \mathrm{~A}} \mathrm{WT}$ and $\mathrm{KO}$ mice........52 
Effect of specific $A_{1} A R(D P C P X), A_{2 A} A R(S C H ~ 58261)$ and $\mathrm{A}_{2 \mathrm{~B}} \mathrm{AR}$ (alloxazine) antagonists on vascular reactivity in

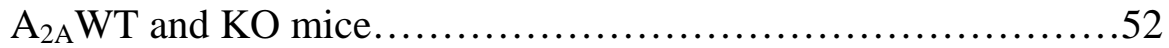

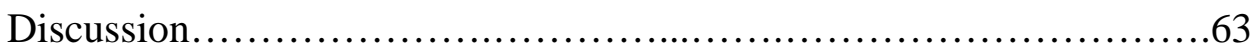

CHAPTER FIVE: EVIDENCE FOR THE ROLE THE OF $\mathrm{A}_{1}$ ADENOSINE RECEPTOR IN ALTERED VASCULAR RESPONSES AND INFLAMMATION

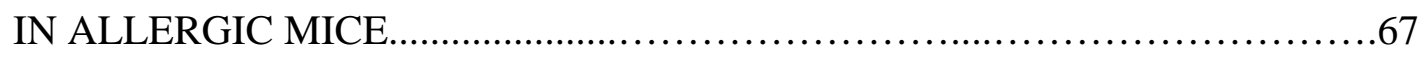

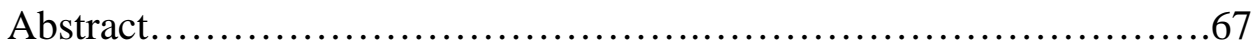

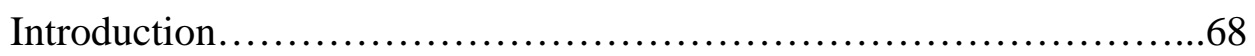

Materials and Methods...............................................71

Animals........................................................ 71

Animal Sensitization..............................................

Preparation of isolated mouse aorta and isometric force

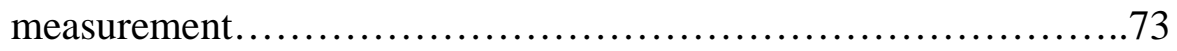

Contraction/relaxation experiments...............................74

Experimental protocol.........................................74

Assessment of systemic inflammation..............................74

Multiplex Cytokine Assay..........................................74

Airway responsiveness to methacholine and NECA...................75

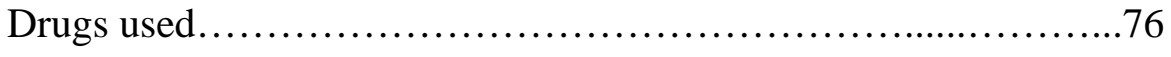

Statistical Analysis..................................................

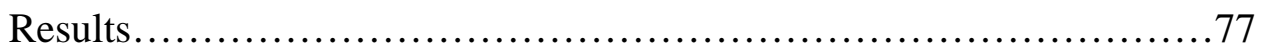


Systemic inflammation in control, allergic and adenosine aerosolized allergic mice.

Vascular reactivity in control, allergic and adenosine aerosolized

allergic mice .77

Endothelial function in control, allergic and adenosine aerosolized allergic mice. .78 Airway responsiveness to methacholine and NECA...................78

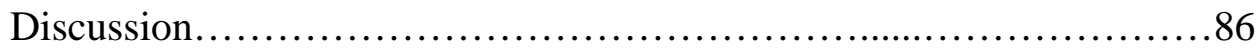

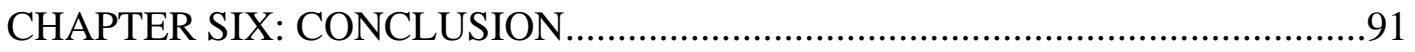

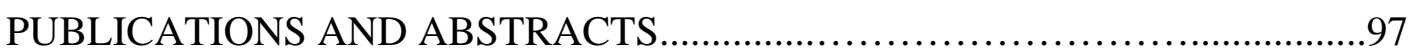

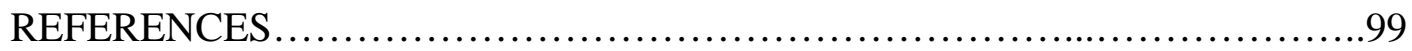

APPENDIX A: Selection of phenylephrine and acetylcholine concentrations

for vascular reactivity experiments.............................109

APPENDIX B: Preliminary data in allergic $\mathrm{A}_{2 \mathrm{~A}} \mathrm{WT}$ and $\mathrm{KO}$ mice.................112

APPENDIX C: Cytokine profile in BAL fluid....................................114

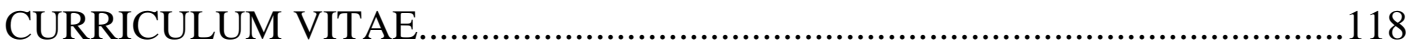




\section{LIST OF TABLES}

Page

Table 3.1 Systemic inflammation as assessed by levels of inflammatory cytokines in plasma of control (CON), adenosine-aerosolized control $(\mathrm{CON}+\mathrm{AD})$, allergic (SEN) and adenosine aerosolized

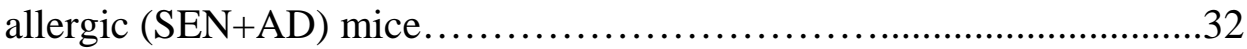

Table 5.1 Systemic inflammation as assessed by levels of inflammatory cytokines in plasma of $\mathrm{A}_{1} \mathrm{WT}$ and $\mathrm{A}_{1} \mathrm{KO}$ control $(\mathrm{CON})$, allergic (SEN) and adenosine-aerosolized allergic (SEN+AD) mice.................................................79 


\section{LIST OF FIGURES}

Page

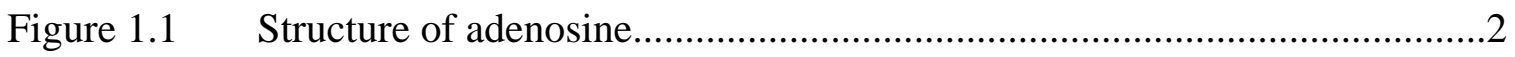

Figure 1.2 Metabolic pathways of adenosine.........................................................

Figure 2.1 Ventilatory cycle from whole body plethysmography............................17

Figure 3.1 Concentration response curves for adenosine-mediated relaxation/contraction in control, adenosine aerosolized control, allergic and adenosine aerosolized allergic mice..................................33

Figure 3.2 Endothelial responses in control, adenosine aerosolized control, allergic and adenosine aerosolized allergic mice...... .34

(A) Effect of acetylcholine on phenylephrine-precontracted aorta. .34

(B) Expression of eNOS by real time RT-PCR................................... 34

Figure 3.3 Expression of $\mathrm{A}_{1}, \mathrm{~A}_{2 \mathrm{~A}}$, and $\mathrm{A}_{2 \mathrm{~B}}$ adenosine receptors in mice aorta of control, allergic and adenosine aerosolized allergic mice. .35 
Figure 3.4 Effect of a specific $\mathrm{A}_{1} \mathrm{AR}$ antagonist, DPCPX on

adenosine-mediated relaxation/contraction in aorta of allergic

and adenosine aerosolized allergic mice............................................36

Figure 3.5 Effect of $\mathrm{A}_{2 \mathrm{~B}} \mathrm{AR}$ antagonist, alloxazine on adenosine-mediated relaxation/contraction in aorta of control mice and allergic and adenosine aerosolized allergic mice...................................................37

Figure 4.1 Concentration response curves for NECA-mediated relaxation/contraction in $\mathrm{A}_{2 \mathrm{~A}} \mathrm{WT}$ and $\mathrm{A}_{2 \mathrm{~A}} \mathrm{KO}$ mice. .54

Figure 4.2 Concentration response curves for CGS 21860-mediated relaxation/contraction in $\mathrm{A}_{2 \mathrm{~A}} \mathrm{WT}$ and $\mathrm{A}_{2 \mathrm{~A}} \mathrm{KO}$ mice. .55

Figure 4.3 Concentration response curves for BAY 60-6583-mediated relaxation/contraction in $\mathrm{A}_{2 \mathrm{~A}} \mathrm{WT}$ and $\mathrm{A}_{2 \mathrm{~A}} \mathrm{KO}$ mice .56

Figure $4.4 \quad$ (A) Endothelial response in $\mathrm{A}_{2 \mathrm{~A}} \mathrm{WT}$ and $\mathrm{A}_{2 \mathrm{~A}} \mathrm{KO}$ mice to acetylcholine. .57

(B) CGS 21860 response in $\mathrm{A}_{2 \mathrm{~A}} \mathrm{WT}$ endothelium-denuded (-E) aorta 
Figure 4.5 Adenosine receptors gene expression in $\mathrm{A}_{2 \mathrm{~A}} \mathrm{WT}$ and $\mathrm{A}_{2 \mathrm{~A}} \mathrm{KO}$ aorta. .58

Figure 4.6 Effect of selective $A_{1}$ antagonist DPCPX on NECA-mediated relaxation/contraction in $\mathrm{A}_{2 \mathrm{~A}} \mathrm{WT}$ and $\mathrm{A}_{2 \mathrm{~A}} \mathrm{KO}$ mice .59

Figure 4.7 Effect of selective $\mathrm{A}_{2 \mathrm{~A}}$ antagonist SCH 58261 on (A) NECA and (B) CGS 21860-mediated relaxation/contraction in $\mathrm{A}_{2 \mathrm{~A}} \mathrm{WT}$ aorta .60

Figure 4.8 Effect of selective $\mathrm{A}_{2 \mathrm{~B}}$ antagonist alloxazine on NECA- mediated relaxation/contraction in $\mathrm{A}_{2 \mathrm{~A}} \mathrm{WT}$ mice.

Figure 4.9 Effect of selective $\mathrm{A}_{2 \mathrm{~B}}$ antagonist alloxazine on NECA-mediated relaxation/contraction in $\mathrm{A}_{2 \mathrm{~A}} \mathrm{KO}$ mice

Figure 5.1 Concentration-response curves for NECA-mediated relaxation/contraction in $\mathrm{A}_{1} \mathrm{WT}$ and $\mathrm{A}_{1} \mathrm{KO}$ control, allergic and adenosine aerosolized allergic group..................................................80

Figure 5.2 Comparison of NECA-mediated aortic response between $\mathrm{A}_{1} \mathrm{KO}$ and $\mathrm{A}_{1} \mathrm{WT}$ allergic mice. .81 
Figure 5.3 Comparison of NECA-mediated aortic response between $\mathrm{A}_{1} \mathrm{KO}$ and $\mathrm{A}_{1} \mathrm{WT}$ allergic and adenosine aerosolized allergic mice.

Figure 5.4 Endothelial response to ACh in control, allergic and adenosine aerosolized allergic $\mathrm{A}_{1} \mathrm{WT}$ and $\mathrm{A}_{1} \mathrm{KO}$ mice........ .83

Figure 5.5 Airway responsiveness to $\mathrm{MCh}$ in $\mathrm{A}_{1} \mathrm{KO}$ and $\mathrm{A}_{1} \mathrm{WT}$ mice....... .84

Figure 5.6 Airway responsiveness to NECA in $\mathrm{A}_{1} \mathrm{KO}$ and $\mathrm{A}_{1} \mathrm{WT}$ mice..................85

Figure 6.1 Proposed pathway for IL-13 signaling effects in asthma.......................96 


\section{LIST OF ABBREVIATIONS}

$\mu \mathrm{g}$

$\mu 1$

$\mathrm{A}_{1} \mathrm{AR}$

$\mathrm{A}_{2 \mathrm{~A}} \mathrm{AR}$

$\mathrm{A}_{2 \mathrm{~B}} \mathrm{AR}$

$\mathrm{A}_{3} \mathrm{AR}$

$\mathrm{AC}$

$\mathrm{ACh}$

ADA

$\mathrm{AD}$

ADP

AK

AMP

ANOVA

ATP

BAL

cAMP

CGS 21860 micro gram

micro liter

$\mathrm{A}_{1}$ adenosine receptor

$\mathrm{A}_{2 \mathrm{~A}}$ adenosine receptor

$\mathrm{A}_{2 \mathrm{~B}}$ adenosine receptor

$\mathrm{A}_{3}$ adenosine receptor

Adenylyl cyclase

Acetylcholine

Adenosine deaminase

Adenosine

Adenosine diphosphate

Adenosine kinase

Adenosine monophosphate

Analysis of variance

Adenosine triphosphate

Bronchoalveolar lavage

Cyclic adenosine monophosphate

2-p-(2-carboxyethyl)phenethylamino-

5' N- ethylcarboxy amidoadenosine

hydrochloride

CON
Control 
COPD

CRC

CRP

CVD

DAG

DMSO

DPCPX

$\operatorname{IgE}$

i.p.

IL-1 $\beta$

IL-4

IL-5

IL-6

IL-10

IL-13

$\mathrm{IP}_{3}$

$\mathrm{kg}$

LO

$\mathrm{LTB}_{4}$

$\mathrm{MCh}$

MCP-1

MIP- $1 \alpha$

$\mathrm{mg}$
Chronic obstructive pulmonary disease

Concentration response curve

C-reactive protein

Cardiovascular disease

Diacylglycerol

Dimethyl sulfoxide

1,3-Dipropyl-8-cyclopentylxanthine

Immunolobulin E

Intraperitoneal

Interleukin $1 \beta$

Interleukin 4

Interleukin 5

Interleukin 6

Interleukin 10

Interleukin 13

Inositol triphosphate

Kilogram

Lipoxygenase

Leukotriene $\mathrm{B}_{4}$

Methacholine

Monocyte chemotactic protein-1

Macrophage inflammatory protein $1 \alpha$

milligram 


\begin{tabular}{|c|c|}
\hline $\mathrm{ml}$ & milliliter \\
\hline $\mathrm{mm}$ & millimeter \\
\hline $\mathrm{mM}$ & millimole \\
\hline NECA & N-ethylcarboxamide-adenosine \\
\hline NP & Nucleoside phosphorylase \\
\hline NO & Nitric oxide \\
\hline OVA & Ovalbumin \\
\hline PCR & Polymerase chain reaction \\
\hline PE & Phenylepherine \\
\hline Penh & Enhanced pause \\
\hline PKA & Protein kinase A \\
\hline $\mathrm{PKC}$ & Protein kinase $\mathrm{C}$ \\
\hline PLC & Phospholipase C \\
\hline SAH & S-Adenosyl-L-homocysteine \\
\hline SAH-hydrolase & S-Adenosyl-L-homocysteine-hydrolase \\
\hline SAM & S-Adenosyl-L methionine \\
\hline SEM & Standard error of the mean \\
\hline SEN & Sensitized \\
\hline $\mathrm{XO}$ & Xanthine oxidase \\
\hline
\end{tabular}




\section{CHAPTER ONE}

\section{INTRODUCTION}

Adenosine is an endogenous purine nucleoside with multiple physiological effects and is produced by all cells. Figure 1.1 shows the chemical structure of adenosine. Some of its regulatory activities are vasodilation of the coronary vessels, including under ischemic conditions, neuromodulation especially in the sleep-wake cycle, effects on the heart including regulating inotropy, chronotropy and many others (Fredholm, 2007).

\section{Generation of adenosine and its metabolism}

Under normal physiological conditions, adenosine is formed by the intracellular conversion of S-adenosyl-L methionine (SAM) to S-adenosyl-L-homocysteine (SAH). This moiety is then converted to adenosine and homocysteine by SAH-hydrolase (Deussen et al., 1989; Pelleg and Porter, 1990). Adenosine can also be produced extracellulary through successive dephosphorylation of ATP; ATP is dephosphorylated to ADP and then AMP which is converted to adenosine via ecto-5'-nucleotidases (Bardenheuer and Schrader, 1986; Forsythe and Ennis, 1999). Adenosine thus produced can be further converted to inosine by the enzyme adenosine deaminase (ADA) and finally is broken down to uric acid which is excreted in urine. There is another pathway through which adenosine is re-converted to AMP via the enzyme adenosine kinase (AK). In addition to being metabolized, adenosine can also act on specific receptors to induce various physiological effects. Figure 1.2 shows the metabolic processes of adenosine production and breakdown. Extra-cellular concentrations of adenosine are elevated several fold during periods of increased metabolic demand, injury or stress such as ischemia (Sparks and Bardenheuer, 1986). 
Figure 1.1 Structure of adenosine

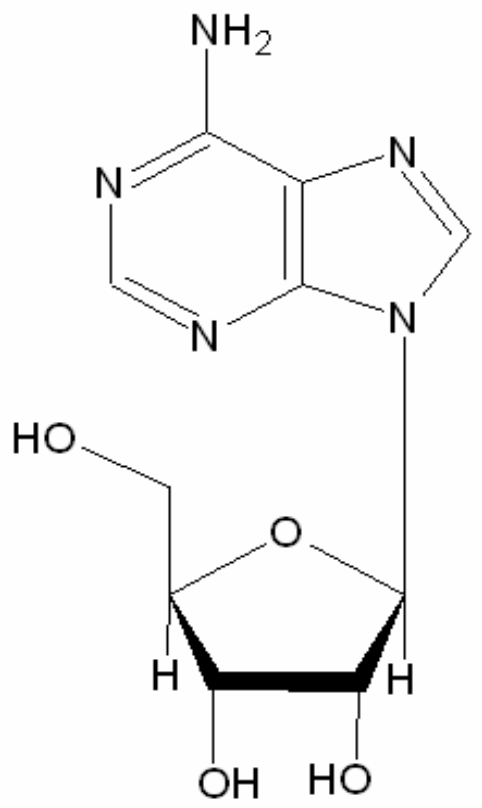


Figure 1.2 Metabolic pathways of adenosine

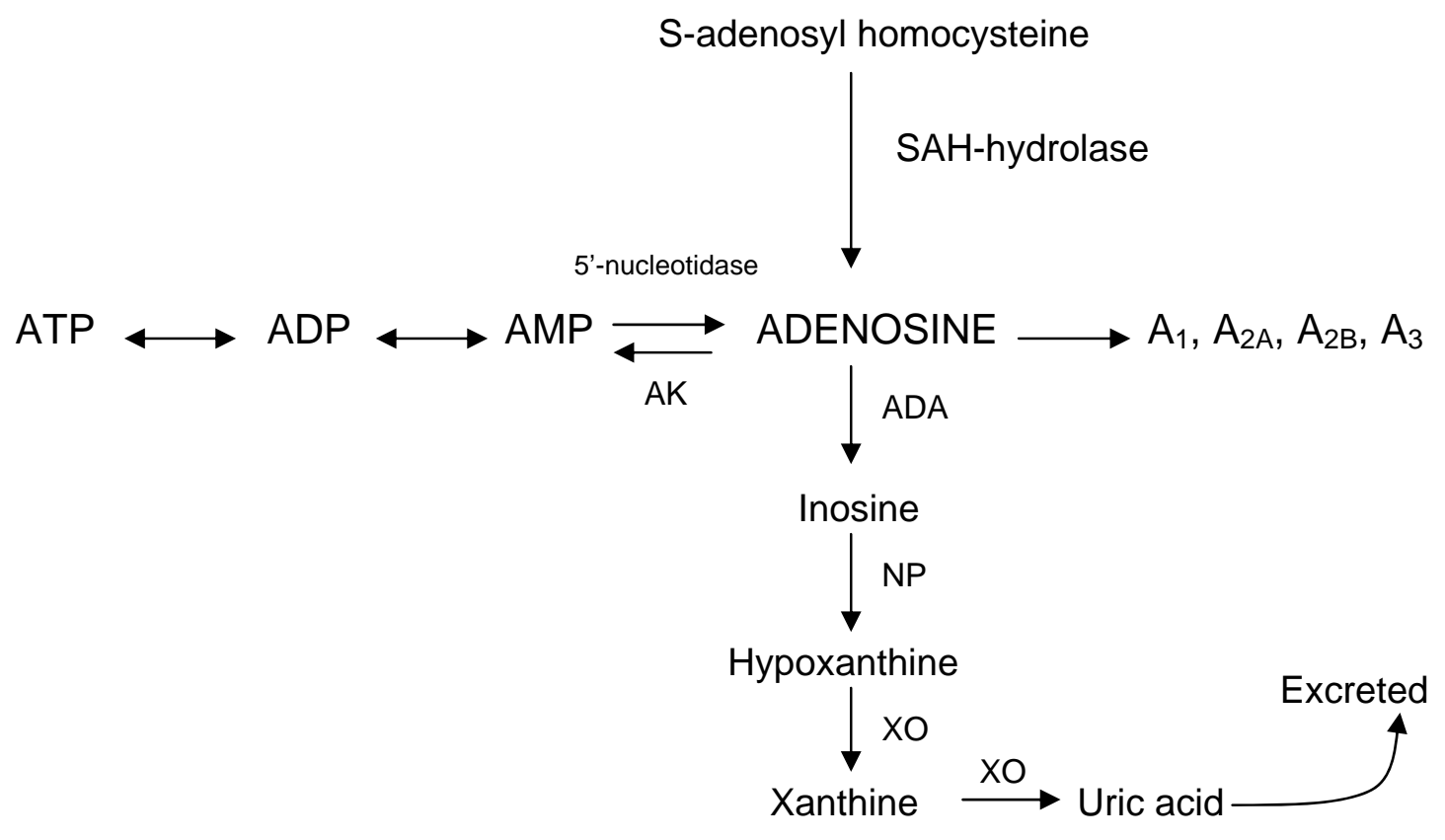




\section{Adenosine receptors}

Adenosine produces various effects through cell surface purinergic receptors and thus far, 4 subtypes have been identified: $A_{1}, A_{2 A}, A_{2 B}$ and $A_{3}$. All four receptors are Gprotein coupled and the effects that adenosine produces depends on both the receptor subtype that is activated as well as the organ/tissue in which the receptor is present. $A_{1}$ and $A_{3}$ receptors are coupled to $G_{i}$ while the $A_{2 A}$ and $A_{2 B}$ receptors are coupled to $G_{s}$. $A_{1}$ and $A_{2 A}$ have a high affinity for adenosine, while the $A_{2 B}$ and $A_{3}$ receptors are considered to be low affinity. The $A_{1}$ receptor signals through $\mathrm{G}_{\mathrm{i} / \mathrm{o}}$ G-proteins and its activation leads to an inhibition of adenylyl cyclase (AC) which causes a lowering of cyclic AMP (cAMP) levels. Signaling through the $\mathrm{A}_{1}$ receptor can also lead to activation of $\mathrm{IP}_{3} / \mathrm{DAG}$ through the PLC pathway (Tawfik et al., 2005). The $A_{2 A}$ receptor signals through the Gs pathway and its activation leads to stimulation of $\mathrm{AC}$ resulting in increased production of cAMP. Activation of the $\mathrm{A}_{2 \mathrm{~A}}$ receptor produces mainly anti-inflammatory effects and this receptor is involved in coronary vasodilation. The $A_{2 B}$ receptor signals through $G_{s / q}$ and its activation can either result in increased cAMP or $\mathrm{IP}_{3} / \mathrm{DAG}$ and $\mathrm{Ca}^{2+}$ levels. Lastly, the $\mathrm{A}_{3}$ receptor signals through $\mathrm{G}_{\mathrm{i}}$ and is negatively coupled to AC.

\section{Asthma}

As previously mentioned, adenosine has varied effects. Of particular interest to this work is the role of adenosine in asthma. Asthma is a chronic lung disease characterized by inflammation and bronchoconstriction. There is a growing incidence of asthma in the U.S. such that many experts believe the country is in the midst of an asthma epidemic. Although there are many treatment options available to manage symptoms, there is no cure for this disease. Over 20 million people have been diagnosed with 
asthma, with 9 million under the age of 18 years; children are particularly susceptible. Allergic asthma accounts for about half of these numbers. Several hypotheses have been put forward to explain the growing asthma epidemic including the hygiene hypothesis and genetic predisposition.

The disease consists of episodic events which manifest as hyper-responsiveness of the airways to common triggers like dust, pollen, cold air, cigarette smoke and other pollutants, resulting in bronchospasm and difficulty in breathing. It can also be induced by exercise and inhalation of cold air. Airway obstruction occurs due to inflammation, excessive mucus production, and hyperreactive bronchial smooth muscle. As a consequence, hypoxemia secondary to hypoventilation is present. Severe acute asthmatic episodes can be life-threatening and require urgent care. Failure to treat prolonged respiratory failure can result in death. Initially, the inflammation observed in asthma is acute in nature but eventually becomes chronic with the progression of the disease, and long term effects of asthma are linked its inflammatory component. Disease management consists of anti-inflammatory drugs and bronchodilators.

\section{Adenosine and asthma}

Adenosine has long been implicated in the pathogenesis of asthma. Inhalation of adenosine was shown to be a potent bronchoprovocant in asthmatic patients (Cushley et al., 1983). This was one of the first studies to demonstrate a role for adenosine in asthma and it established that guanosine, another purine nucleoside, did not have the same effect. Inosine, the deaminated adenosine metabolite, did not produce bronchoconstriction (Mann et al., 1986b), suggesting that the effect on bronchial smooth muscle was specific to adenosine and possibly involved adenosine receptors. Asthmatic patients also had 
significantly higher levels of adenosine in bronchoalveolar lavage fluid (BAL) and exhaled breath condensate than normal healthy subjects (Driver et al., 1993; Huszar et al., 2002). Adenosine can also have indirect effects in the lungs; it causes degranulation of mast cells which leads to the release of histamine and subsequent cascade of events including $\mathrm{H}_{1}$-receptor-mediated bronchoconstriction and inflammatory response (Fozard and Hannon, 2000; Oldenburg and Mustafa, 2005). This mast-cell mediated response is believed to occur through the $\mathrm{A}_{2 \mathrm{~B}}$ receptor although this has not been conclusively proven (Zhong et al., 2003).

Studies done using mice lacking the ADA enzyme have shown that these mice have large amounts of adenosine in their lungs and severe lung inflammation (Blackburn et al., 2000). In fact, these mice were unable to survive beyond three weeks due to respiratory distress. Further studies using ADA deficient mice demonstrated the presence of eosinophilia in the lungs and periphery, extensive mast cell degranulation and increased levels of serum IgE (Zhong et al., 2001). There is evidence that adenosine causes recruitment of inflammatory cells to the lung (Fan and Mustafa, 2002) and amplification of the inflammatory response (Spicuzza et al., 2006). Despite all of these data linking adenosine to asthma, the exact extent of adenosine implication and specific roles of the four adenosine receptors still have to be delineated. 


\section{Reactive airway diseases and cardiovascular complications}

An interesting facet noted in epidemiological studies is that people suffering from asthma, chronic obstructive pulmonary disease (COPD) and reactive airway diseases are at an increased risk for developing cardiovascular disease (CVD) (Gan et al., 2004; Schanen et al., 2005; Sin and Man, 2005). There is an association between atherosclerosis and stroke with reactive airway diseases. One study found that adult-onset asthma was associated with increased carotid atherosclerosis in women (Onufrak et al., 2007). Many studies have shown that impaired lung function is a risk factor for CVD (Tockman et al., 1995). Bronchial hyperresponsiveness to methacholine is associated with increased carotid intima-media thickness (Zureik et al., 2004). One of the leading causes for hospitalizations and deaths occurring in COPD patients is cardiovascular events (Sidney et al., 2005).

Inflammation is a key event in CVD and several inflammatory mediators and markers are associated with it, including C-reactive protein (CRP), plasma fibrinogen, leucocytes, and interleukins (IL-1 $\beta,-4,-5,-6,-8$ and -13). CRP has been implicated in atherosclerosis, and levels of this protein are elevated in this condition. The level of CRP is considered one of the best predictors of the risk of CVD (Yudkin et al., 1999; Pearson et al., 2003). Interleukins, in particular IL-6 (Yudkin et al., 2000), are also important markers of CVD.

Recent evidence in animal models indicates that $\mathrm{CV}$ complications associated with asthma are independent of asthma therapy and could be a result of asthma itself. Myocardial ischemia-reperfusion injury was enhanced in a rabbit model of systemic allergy and asthma (Hazarika et al., 2004) and allergic inflammation in the airways 
enhanced neutrophil recruitment to the myocardium and severity of ischemia-reperfusion in a murine model (Hazarika, 2005).

Asthma thus, is a risk factor for cardiovascular disease. However, its potential as a risk factor in CVD has not been widely studied with respect to mechanisms underlying the phenomenon, nor have the effects of adenosine been explored on cardiovascular parameters in asthma. Work done in this dissertation attempts to shed light on both of these aspects.

\section{Animal models of asthma}

The use of animal models has been one of the mainstays for asthma research. Species including mice, rats, rabbits, guinea pigs, sheep and dogs amongst others have been used (Abraham et al., 1983; Muccitelli et al., 1987; de Weck et al., 1997; Liu et al., 2005). There are several advantages and disadvantages in employing animal models to study asthma. The principle criticism in using animal models of asthma is that none of the species develop the disease spontaneously nor exhibit the episodic airway hyperresponsiveness of the disease that is characteristic of the human condition, i.e., it is not possible to reproduce the exact human disease in animals. The asthma phenotype generated in animal models is a Th-2 type response with acute inflammation and increased responsiveness to bronchoprovocants observed. The main advantage to using animal models is the ability to study intact systems and carrying out in vivo experiments. Many of these models are also cost effective and a number of species specific probes have been developed which aid greatly in research. For mechanistic purposes, animal models are extremely useful and also for drug screening purposes. 


\section{Murine models of asthma}

Mice are very commonly used to study asthma, especially for modeling allergic responses in the airways and lungs. With the increasing number of genetically modified mice available, these are ideal tools for studying specific aspects of the disease. There are knock-out mice for all four adenosine receptors as well as mice in which ADA has been knocked out and double knock-outs with specific adenosine receptors. Mice in which specific cytokines have been knocked out are also available to study inflammatory signaling with respect to asthma. These include IL-13 knock out mice which exhibit a lack of airway remodeling characteristic of asthma (Kumar et al., 2002). One of the main advantages of using mice to duplicate certain asthmatic features is the ease of various tools with which allergic models can be developed and also the easy availability and cost effectiveness of such models. Mice can be sensitized to various antigens including dustmite (O'Brien et al., 1996), (Johnson et al., 2004), ragweed extracts (Oldenburg and Mustafa, 2005; Fan and Jamal Mustafa, 2006), and one of the more commonly used allergens, ovalbumin, in a reasonable time frame (Nadeem et al., 2007). 


\section{Purpose and Project Summary}

The purpose of this investigation is to understand the effects of asthma beyond the lungs, specifically to determine if there is any alteration in vascular reactivity. Since adenosine has major implications in both asthma and on the vasculature, it is important to elucidate the adenosine-mediated systemic and vascular effects in asthma. Lastly, identifying the possible adenosine receptor(s) involved in inflammatory and other changes would be able to provide further insights in understanding the profound and diverse effects of adenosine in asthma. Determining which receptor is involved in the vascular changes is necessary for developing potential therapeutic approaches to asthma, particularly with respect to targeting and reducing the commonly reported adverse vascular effects that are a consequence with asthma. With this in mind, the following aims were developed:

Aim 1: Identify markers of systemic and local arterial inflammation in an allergic murine model of asthma.

\section{Hypotheses}

(a): Chronic inflammatory disease of the airway and lung leads to an increase in systemic levels of several inflammatory mediators including TNF- $\alpha$, IL-1 $\beta$, IL-4, and IL13

(b) Chronic inflammatory disease of the airway and lung can lead to local inflammation of blood vessels (aorta). 
Aim 2: Characterize the adenosine receptor sub-type(s) involved in altered vascular response and quantify their expression levels in our model of asthma.

\section{Hypotheses}

(a) Multiple adenosine receptors $\left(\mathrm{A}_{1}, \mathrm{~A}_{2 \mathrm{~A}}, \mathrm{~A}_{2 \mathrm{~B}}\right.$, and $\left.\mathrm{A}_{3}\right)$ regulate vascular responses and are differentially activated in an allergic inflammatory model.

(b) Specific adenosine receptor(s) $\left(\mathrm{A}_{1}, \mathrm{~A}_{2 \mathrm{~A}}, \mathrm{~A}_{2 \mathrm{~B}}, \mathrm{~A}_{3}\right)$ are either up-regulated or downregulated in asthma

Aim 3: Identify the adenosine receptor subtype(s) involved in vascular inflammation. Hypothesis: The interaction between inflammatory mediators and adenosine through specific adenosine receptors is central to a cascade of pro-inflammatory events. 


\section{CHAPTER TWO}

\section{MATERIALS AND METHODS}

\section{Mice}

Balb/c mice, 8-10 weeks old males were obtained from Harlan Sprague Dawley (Indianapolis, $\mathrm{IN}$ ). To study vascular effects of $\mathrm{A}_{2 \mathrm{~A}}$ receptor-activation, $\mathrm{A}_{2 \mathrm{~A}} \mathrm{KO}$ and $\mathrm{WT}$ mice were used which were initially obtained from Dr. Catherine Ledent, University of Brussels, Belgium and maintained as a breeding colony at WVU. Male and female mice aged 12-14 weeks were used for all $A_{2 A}$ adenosine receptor experiments. $A_{1} \mathrm{KO}$ mice were kindly provided by Dr. Stephen Tilley, University of North Carolina, Chapel Hill and mice aged 8-12 weeks were used for experiments. All mice were kept in community cages with 12-hr periods of light and dark cycles and were maintained on a ragweed-free diet with access to water ad libitum. All animal care and experimentation used in this study were carried out under protocols approved by the Institutional Animal Care and Use Committee of West Virginia University (Animal Use Protocol \# 05-0603 and \#061009); animal procedures were monitored by this committee and were done in accordance with the provisions of the NIH "Guide for the Care and Use of Laboratory Animals."

\section{Animal sensitization protocol}

Sensitization of mice was performed according to the previously established protocols including one described from this laboratory (Fan and Mustafa, 2002; Fan et al., 2003; Oldenburg and Mustafa, 2005; Fan and Mustafa, 2006; Mustafa et al., 2007). This model of allergic asthma has been shown to develop airway inflammation and 
airway hyper-reactivity to methacholine. In brief, mice were sensitized on days 1 and 6 with i.p. injections of ragweed allergen (Greer Laboratories, Lenoir, NC), $200 \mu \mathrm{g}$ per dose, with $200 \mu \mathrm{L}$ Imject Alum (Pierce Laboratories, Rockford, IL). Non-sensitized control animals received only the Imject alum with the same volumes. Ten days after sensitization, the mice were placed in a Plexiglas chamber and challenged with $1 \%$ aerosolized ragweed or with $0.9 \%$ saline as a control, using an ultrasonic nebulizer (DeVilbiss, Somerset, PA) for $20 \mathrm{~min}$ both in the morning and afternoon for three consecutive days. The aerosolization of allergen was performed at a flow rate of 2 $\mathrm{mL} / \mathrm{min}$, and the aerosol particles had a median aerodynamic diameter of less $4 \mu \mathrm{m}$ (DeVilbiss).

In addition, acute elevations in lung adenosine levels were produced experimentally by adenosine inhalation $(6 \mathrm{mg} / \mathrm{ml}$ for $2 \mathrm{~min}$ on day 14) in one group of sensitized-challenged mice and one group of control mice to further enhance allergeninduced effects. This dose was chosen based on previous studies in this model (Fan and Mustafa, 2002; Fan and Mustafa, 2006). The time frame for experiments was 24-hr postadenosine inhalation, chosen on the basis of an earlier study from this lab which showed maximum eosinophilic inflammation in airways after $24 \mathrm{hr}$ of adenosine inhalation (Fan and Jamal Mustafa, 2006), which is a hallmark of asthmatic inflammation. Twenty-four hours after the last challenge, animals were sacrificed for collection of aorta and blood for further experiments. 


\section{In-vitro organ bath: For vascular reactivity (aorta)}

\section{Preparation of mouse isolated aorta and isometric force measurement}

Mice were sacrificed by anesthesia with pentabarbitol sodium $(65 \mathrm{mg} / \mathrm{kg}$, i.p. $)$ followed by thoracotomy and removal of the aorta. This was then carefully cleaned to remove fat and connective tissue without damaging the tissue and was then cut transversely into 3-4 mm rings. The rings were mounted vertically between two stainless steel wire hooks and then suspended in $10 \mathrm{~mL}$ organ baths containing Krebs-Henseleit buffer. The Krebs-Henseleit buffer (pH 7.4) containing $118 \mathrm{mM} \mathrm{NaCl}, 4.8 \mathrm{mM} \mathrm{KCl}, 1.2$ $\mathrm{mM} \mathrm{MgSO}_{4}, 1.2 \mathrm{mM} \mathrm{KH}_{2} \mathrm{PO}_{4}, 25 \mathrm{mM} \mathrm{NaHCO}_{3}, 11 \mathrm{mM}$ glucose and $2.5 \mathrm{mM} \mathrm{CaCl}_{2}$ was maintained at $37^{\circ} \mathrm{C}$ with continuous bubbling of $95 \% \mathrm{O}_{2}$ and $5 \% \mathrm{CO}_{2}$. For measurement of isometric force response, aortic rings were equilibrated for $90 \mathrm{~min}$ with a resting force of $1 \mathrm{~g}$ (Tawfik et al., 2005; Ansari et al., 2007b) and change of the bathing solution at 15 min interval. At the end of equilibration period, tissues were contracted twice with 50 $\mathrm{mM} \mathrm{KCl}$ to determine the contractility of individual aortic rings, which were washed out with Krebs-Henseleit buffer. Aortic rings were then constricted with phenylephrine (PE, $10^{-7} \mathrm{M}$ ) to obtain a steady contraction and changes in tension were monitored continuously with fixed range precision force transducer (TSD, $125 \mathrm{C}$, BIOPAC system) connected to the differential amplifier (DA 100B, BIOPAC system). The data were recorded using a MP100 digital acquisition system and analyzed using Acknowledge 3.5.7 software (BIOPAC system). After equilibration, the responsiveness and stability of individual rings were checked by successive administration of a submaximally effective concentration of PE $\left(10^{-7} \mathrm{M}\right)$. The integrity of the vascular endothelium was assessed 
pharmacologically by acetylcholine $\left(\mathrm{ACh} ; 10^{-7} \mathrm{M}\right)$ to produce relaxation of $\mathrm{PE}$ precontracted rings. A relaxation of $\geq 50 \%$ with $\mathrm{ACh}$ was considered as normal. Aortic rings were then washed several times with Krebs-Henseleit solution, and allowed to equilibrate for $30 \mathrm{~min}$ before the experimental protocol began in which concentration-responsiveness to various drugs was measured including NECA (non-selective adenosine analog; $10^{-11}$ $10^{-5} \mathrm{M}$ ), adenosine $\left(10^{-11}-10^{-4} \mathrm{M}\right)$ and CGS 21860 (selective $\mathrm{A}_{2 \mathrm{~A}}$ agonist; $10^{-11}-10^{-6} \mathrm{M}$ ) were run parallel in aortic rings. In all cases, the drug was added to yield the next higher concentration only when the response to the earlier dose reached a steady state. In experiments where the effects of an antagonist were measured, it was added $30 \mathrm{~min}$ before contraction of the tissue with PE, and was present throughout the experiments.

Contraction/relaxation responses were expressed as a percentage increase/decrease in the contraction with respect to PE (alone) in response to each concentration of agonist used.

\section{Airway responsiveness}

Airway hyperresponsiveness was measured by whole body plethysmography. Unrestrained mice were placed in Plexiglass chambers (Buxco Electronics, Wilmington, NC) and pressure fluctuations during ventilatory cycles were monitored by pressure transducers. Data was calculated in the form of enhanced pause (Penh) according to a previously described protocol (Hamelmann et al., 1997).

Penh is a dimensionless index of airway obstruction, and higher the Penh value, the greater is the obstruction. The waveform (Hamelmann et al., 1997; Drazen et al., 1999) describing the process of Penh calculation is shown in figure 2.1 and 
mathematically, Penh is obtained by the following equation (Hamelmann et al., 1997;

Drazen et al., 1999).

Penh= PEF/PIF* ${ }^{*}$ TE/Rt-1)

$\mathrm{PEF}=$ Peak expiratory height

$\mathrm{PIF}=$ Peak inspiratory height

$\mathrm{TE}=$ Expiratory time

$\mathrm{Rt}=$ Time to expire $65 \%$ of the volume

Pause $=($ TE/RT $)-1$

$\mathrm{Penh}=\mathrm{PEF} / \mathrm{PIF} *$ Pause 
Figure 2.1: Ventilatory cycle from whole body plethysmography. Te=expiratory time;

$\mathrm{Rt}=$ Time to expire $65 \%$ of the volume; $\mathrm{PEF}=$ Peak expiratory height; $\mathrm{PIF}=$ Peak inspiratory height

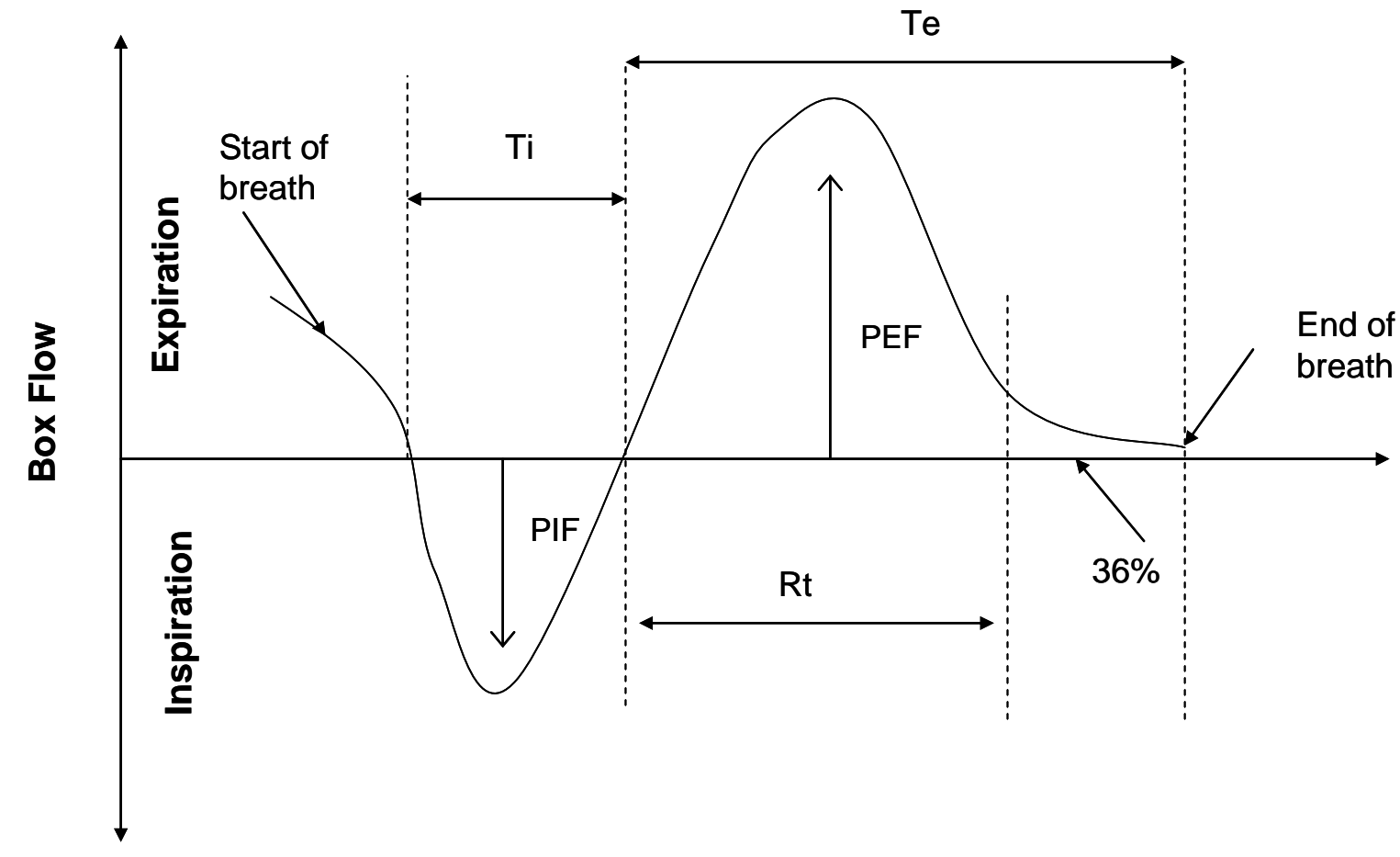




\title{
CHAPTER THREE
}

\section{ADENOSINE-MEDIATED ALTERATION OF VASCULAR REACTIVITY AND INFLAMMATION IN A MURINE MODEL OF ASTHMA}

American Journal of Physiology, May 2008

(Used with permission from Am J Physiol Heart Circ Phsyiol)

\begin{abstract}
Chronic respiratory disorders such as asthma are believed to be associated with adverse cardiovascular events. We hypothesize that asthmatic inflammation translates into systemic inflammation and alters vascular responses where adenosine (AD) plays an important role. Therefore, this study investigated the effects of aerosolized AD, used to elevate lung $\mathrm{AD}$ levels, on vascular reactivity and inflammation in our allergic mouse model of asthma. Balb/c mice were divided into four groups: control $(\mathrm{CON}), \mathrm{CON}+$ aerosolized AD (CON + AD), allergen sensitized and challenged (SEN), and SEN + aerosolized AD (SEN + AD). The animals were sensitized with ragweed (200 $\mu \mathrm{g} \mathrm{ip})$ on days 1 and 6 , followed by 1\% ragweed aerosol challenges from days 11 to 13 . On day 14 , the $\mathrm{CON}+\mathrm{AD}$ and $\mathrm{SEN}+\mathrm{AD}$ groups received a single $\mathrm{AD}$ aerosol challenge $(6 \mathrm{mg} / \mathrm{ml})$ for $2 \mathrm{~min}$, followed by the collection of the aorta and plasma on day 15. Organ bath experiments showed concentration-dependent aortic relaxations to $\mathrm{AD}$ in the $\mathrm{CON}$ and $\mathrm{CON}+\mathrm{AD}$ groups, which were impaired in the SEN and SEN + AD groups. Real-time PCR data showed changes in aortic $A D$ receptors (ARs), with the expression of $A_{1} A R s$ up-regulated, whereas the expression of $\mathrm{A}_{2} \mathrm{ARs}$ and endothelial nitric oxide synthase
\end{abstract}


genes were down-regulated, resulting in an impairment of vasorelaxation in the SEN and $\mathrm{SEN}+\mathrm{AD}$ groups. The $\mathrm{A}_{1} \mathrm{AR}$ antagonist 1,3-dipropyl-8-cyclopentylxanthine (DPCPX) reversed the impairment in vasorelaxation observed in the SEN and SEN + AD groups, whereas the $\mathrm{A}_{2 \mathrm{~B}} \mathrm{AR}$ antagonist alloxazine inhibited vasorelaxation in all groups. Allergen challenge caused systemic inflammation in allergic mice, with $\mathrm{AD}$ aerosol further enhancing it as determined by the inflammatory cytokines profile in plasma. In conclusion, asthmatic mice showed altered vascular reactivity and systemic inflammation, with $\mathrm{AD}$ aerosol further exacerbating these effects.

\section{Introduction}

Asthma, a chronic disease affecting $10 \%$ of the population in North America, is characterized by perpetuation and amplification of inflammation in the airways and systemic circulation (Busse and Lemanske, 2001; Braman, 2006). Over the past two decades, adenosine has been increasingly implicated in the pathophysiology of asthma. Chronic cellular stress, inflammation and tissue damage observed in asthmatic airways are associated with increases in adenosine levels (Driver et al., 1993). The inhalation of adenosine leads to bronchoconstriction in asthmatics as opposed to normal subjects who show no response to adenosine (Cushley et al., 1984). The elevation in lung adenosine levels observed in adenosine deaminase (ADA)-deficient mice lead to severe pulmonary inflammation, airway hyper-reactivity and airway remodeling (Chunn et al., 2001; Blackburn and Kellems, 2005), suggesting that a chronic elevation of adenosine levels can lead to the promotion of lung inflammation. 
Several epidemiological studies have reported that people suffering from chronic respiratory diseases such as asthma are at an increased risk for developing cardiovascular complications (Drislane et al., 1987; Toren and Lindholm, 1996; Iribarren et al., 2004; Knoflach et al., 2005). Systemic inflammation in these patients is believed to be a consequence of airway inflammation (Jousilahti et al., 2002; Nadeem et al., 2003), which may be one of the reasons for altered cardiovascular parameters in these patients. Some recent studies have also reported enhanced systemic inflammation, myocardial ischemiareperfusion injury and neutrophil recruitment to the myocardium in animal models of allergic asthma (Hazarika et al., 2004, 2007). However, no study so far has attempted to establish a link between airway inflammation, vascular reactivity and systemic inflammation, especially in relation to adenosine.

Adenosine has a well established role in the control of vascular tone, and its effects are exerted through the activation of the four different adenosine receptor (AR) subtypes: $A_{1}, A_{2} A, A_{2 B}$, and $A_{3}$ (Tabrizchi and Bedi, 2001). $A_{1}$ and $A_{3}$ ARs have been shown be involved in vasoconstriction (Shepherd et al., 1996; Talukder et al., 2002b; Hansen et al., 2003; Tawfik et al., 2005) whereas A2A and A2B ARs cause vasorelaxation of aorta (Lewis et al., 1994; Grbovic and Radenkovic, 2003; Ansari et al., 2007b). However, the modulation of aortic ARs expression in response to allergen and adenosine aerosol challenge as an added insult in a murine model of asthma has not been previously studied.

Allergen has been shown to cause the release of adenosine among other inflammatory mediators from allergic lung and activated leukocytes (Mann et al., 1986b; Mann et al., 1986a). Adenosine generated in allergic lungs may be involved in the release 
of further chemotactic and inflammatory mediators in the lung and systemic circulation by acting on its receptors present on different cells including mast cells, eosinophils, neutrophils and other inflammatory cells (Driver et al., 1991; Fan and Jamal Mustafa, 2006; Nadeem and Mustafa, 2006; Spicuzza et al., 2006). This has been confirmed by recent observations where experimentally induced temporary elevations in lung adenosine levels through the inhalation of adenosine (resulting from breakdown of adenosine 5'-monophosphate) have been shown to cause an increase in infiltration of eosinophils in patients with asthma (van den Berge et al., 2004). A recent study from our lab has also shown increased release of inflammatory cell markers in the lung and plasma after inhalation of adenosine aerosol in allergic mice (Fan and Mustafa, 2002). These studies thus suggest that adenosine inhalation amplifies allergen-induced airway inflammation in the lungs.

Therefore, this study was undertaken to investigate the effects of inhaled adenosine on vascular reactivity and systemic inflammation using our murine model of asthma. Our data suggest that asthmatic mice have altered peripheral vascular reactivity and systemic inflammation, with inhaled adenosine further exacerbating these effects.

\section{Materials and Methods}

Animals: Balb/c mice, 8-10-wk-old males, were obtained from Harlan Sprague Dawley (Indianapolis, IN). The animals were maintained on a ragweed-free diet. All experimental animals used in this study were under a protocol approved by the Institutional Animal Care and Use Committee of West Virginia University.

Animal sensitization: Sensitization was performed according to the protocol described 
earlier from this laboratory (Fan and Mustafa, 2002; Fan et al., 2003; Oldenburg and Mustafa, 2005; Fan and Jamal Mustafa, 2006; Mustafa et al., 2007). This model of allergic asthma has been shown to develop airway inflammation and airway hyperreactivity to methacholine. The study comprised of four groups of animals: 1) Control $(\mathrm{CON}), 2)$ Control challenged with $6 \mathrm{mg} / \mathrm{ml}$ of adenosine aerosol for $2 \mathrm{~min}$ on day 14 $(\mathrm{CON}+\mathrm{AD}), 3)$ allergen sensitized and challenged $(\mathrm{SEN})$, and 4) allergen sensitized and challenged further challenged with $6 \mathrm{mg} / \mathrm{ml}$ of adenosine aerosol for 2 min on day 14 $(\mathrm{SEN}+\mathrm{AD})$. Mice were sensitized on days 1 and 6 with i.p. injections of ragweed allergen (Greer Laboratories, Lenoir, NC), $200 \mu \mathrm{g}$ per dose with $200 \mu \mathrm{L}$ Imject Alum (Pierce Laboratories, Rockford, IL). Non-sensitized control animals received only the Imject alum with the same volumes. Ten days after sensitization, the mice were placed in a Plexiglas chamber and challenged with $1 \%$ aerosolized ragweed or with $0.9 \%$ saline as a control, using an ultrasonic nebulizer (DeVilbiss Somerset, PA) for 20 min both in the morning and afternoon for three consecutive days. The aerosolization of allergen was performed at a flow rate of $2 \mathrm{~mL} / \mathrm{min}$, and the aerosol particles had a median aerodynamic diameter of less $4 \mu \mathrm{m}$ (De Vilbiss).

Acute elevations in lung adenosine levels were produced experimentally by adenosine inhalation (6 $\mathrm{mg} / \mathrm{ml}$ for $2 \mathrm{~min}$ on day 14 ) to $\mathrm{SEN}+\mathrm{AD}$ group to further enhance allergen-induced effects (the control for this group was CON+AD). This dose was chosen based on our previous studies in this model (Fan and Mustafa, 2002; Fan and Jamal Mustafa, 2006). Adenosine inhalation in this model has been shown to enhance allergeninduced airway inflammation and airway hyper-reactivity to adenosine (or its analog NECA) (Fan and Mustafa, 2002; Fan et al., 2003; Fan and Jamal Mustafa, 2006). ADA- 
deficient mice having sustained and chronic elevations in lung adenosine levels have also been shown to have similar features (Chunn et al., 2001). We chose 24-h post adenosine inhalation for our current studies based on an earlier study from our lab which showed maximum eosinophilic inflammation in airways after $24 \mathrm{~h}$ of adenosine inhalation (Fan and Jamal Mustafa, 2006), which is a hallmark of asthmatic inflammation. CON and SEN groups received only saline on day 14 . Twenty-four $\mathrm{hr}$ after the last challenge, animals were sacrificed for collection of aorta and blood for further experiments.

\section{Preparation of isolated mouse aorta and isometric force measurement}

Mice were euthanized by anesthesia with pentabarbitol sodium ( $65 \mathrm{mg} / \mathrm{kg}$ ip) followed by thoracotomy and the removal of the aorta, which was then cut transversely into 3 to 4-mm rings. The rings were mounted vertically between two stainless steel wire hooks and then suspended in 10-ml organ baths containing Krebs-Henseleit buffer. The Krebs-Henseleit buffer (pH 7.4), containing (in mM) $118 \mathrm{NaCl}, 4.8 \mathrm{KCl}, 1.2 \mathrm{MgSO}_{4}, 1.2 \mathrm{KH}_{2} \mathrm{PO}_{4}, 25$ $\mathrm{NaHCO}_{3}, 11$ glucose, and $2.5 \mathrm{CaCl}_{2}$, was maintained at $37^{\circ} \mathrm{C}$ with continuous bubbling of $95 \% \mathrm{O}_{2}-5 \% \mathrm{CO}_{2}$. For the measurement of isometric force response, the aortic rings were equilibrated for $90 \mathrm{~min}$ with a resting force of $1 \mathrm{~g}$ and a change of the bathing solution at 15-min intervals. The resting force of $1 \mathrm{~g}$ has been used earlier in our laboratory (Tawfik et al., 2005; Ansari et al., 2007b). At the end of the equilibration period, the tissues were contracted with $50 \mathrm{mM} \mathrm{KCl}$ to check the contractility of individual aortic rings twice, which were washed out with Krebs-Henseleit buffer. The aortic rings were then constricted with phenylephrine $\left(\mathrm{PE} ; 10^{-7} \mathrm{M}\right)$ to obtain a steady contraction, and changes in tension were monitored continuously with a fixed-range 
precision force transducer (TSD 125C; Biopac) connected to a differential amplifier (DA 100B; Biopac). The data were recorded using the MP100 Biopac digital acquisition system and analyzed using Acknowledge 3.5.7 software (Biopac).

\section{Contraction/relaxation experiments}

After equilibration, the responsiveness and stability of individual rings were checked by successive administration of a submaximally effective concentration of PE $\left(10^{-7} \mathrm{M}\right)$. The integrity of the vascular endothelium was assessed pharmacologically by acetylcholine $\left(10^{-7} \mathrm{M}\right)$ to produce the relaxation of PE-precontracted rings. The aortic rings were then washed several times with Krebs-Henseleit solution and allowed to equilibrate for $30 \mathrm{~min}$ before the experimental protocol began.

\section{Experimental protocol}

The concentration-response curves (CRCs) for adenosine $\left(10^{-11}-10^{-4} \mathrm{M}\right)$ were run in parallel in aortic rings from all the groups. In all cases, adenosine was added to yield the next higher concentration only when the response to the earlier dose reached a steady state. In experiments where the effects of an antagonist were measured, it was added 30 min before the contraction of the tissue with $\mathrm{PE}$ and was present throughout the experiments.

\section{Real time PCR: $A_{1}, A_{2 A}, A_{2 B}, A_{3} A R$ and eNOS genes expression}

The aortic tissues from all experimental groups were processed for total RNA isolation using the TRIzol reagent from Life Technologies/Invitrogen, followed by DNase 
treatment to eliminate potential genomic DNA contamination as described recently by our laboratory (Ansari et al., 2007b). This was followed by a conversion of $0.5 \mu \mathrm{g}$ of total RNA into cDNA using a high-capacity cDNA archive kit (Applied Biosystems, Foster City, CA) in a total volume of $100 \mu$ l. Real-time PCR was then performed using an ABI PRISM 7300 detection system (Applied Biosystems) using Taqman Universal Mastermix (Applied Biosystems, Branchburg, NJ) according to the instructions of the manufacturer. The reaction volume ( $25 \mu \mathrm{l})$ consisted of (in $\mu$ l) $12.52 x$ Taqman Universal Mastermix, 1 cDNA, and 1.25 20x 6-carboxy-fluorescein-labeled Taqman gene expression assay master mix solution. For the real-time PCR of the concerned genes $\left[\mathrm{A}_{1^{-}}, \mathrm{A}_{2 \mathrm{~A}^{-}}, \mathrm{A}_{2 \mathrm{~B}^{-}}\right.$, and $\mathrm{A}_{3} \mathrm{AR}$ and endothelial nitric oxide synthase (eNOS)], the Taqman inventoried assays-on-demand gene expression products (assay identifications for $\mathrm{A}_{3^{-}}, \mathrm{A}_{2 \mathrm{~B}^{-}}, \mathrm{A}_{2 \mathrm{~A}^{-}}$, and $\mathrm{A}_{1} \mathrm{AR}$ and eNOS,

respectively, are Mm00802076_m1, Mm00839292_m1, Mm00802075_m1, Mm01308023_m1, and Mm00435204_m1) were purchased from Applied Biosystems. $18 \mathrm{~S}$ ribosomal RNA was used as an endogenous control. The fold difference in the expression of target cDNA was determined using the comparative cycle threshold method as described earlier (Livak and Schmittgen, 2001).

\section{Assessment of systemic inflammation}

Mice were euthanized by pentobarbitone sodium ( $65 \mathrm{mg} / \mathrm{mL}$, i.p.), followed by collection of blood by cardiac puncture in heparinized syringes. The blood collected from different groups was centrifuged at $800 \mathrm{~g}$ for $10 \mathrm{~min}$ at $4^{\circ} \mathrm{C}$ and the resulting plasma was used for cytokine and C-reactive protein (CRP) assays. 
Multiplex cytokine assay: Multiplex cytokine assay of IL-1 $\alpha$, IL-1 $\beta$, IL-2, IL-4, IL-5, IL-6, IL-7, IL-9, IL-10, IL-12 (p70), , IL-13, IL-15, IL-17, TNF $\alpha$, IFN $\gamma$, GMCSF, MIP$1 \alpha$, MCP-1, KC, RANTES, IP-10, G-CSF in the plasma was measured by a commercial kit from Linco Research (St. Charles, Missouri) using the Luminex 200 system (Luminex Corp., Austin, Tx), which is a multianalyte bioassay detection system capable of performing up to 100 assays simultaneously in a single microtiter plate well. This system uses polystyrene microspheres internally dyed with red and infrared fluorophores that can be individually identified. The fluorescent microspheres were coated with capturing antibodies specific for different chemokines. The chemokine-captured beads after incubation with the sample were then mixed with phycoerythrin-conjugated detection antibodies to form immune complexes. Following incubation, washing and acquisition of fluorescence data, the concentration results were generated in graphical format using the standard curve generated for each cytokine. Results were expressed in $\mathrm{pg} / \mathrm{mL}$.

C-reactive protein assay: $\mathrm{C}$-reactive protein was measured in plasma with a mouse high-sensitive ELISA kit according to the instruction manual (Kamiya Biomedical Company, Seattle, WA). This kit specifically detects mouse CRP. Results were expressed in $\mathrm{ng} / \mathrm{mL}$.

\section{Drugs used}

Acetylcholine, adenosine and phenylephrine were dissolved in distilled water. 1,3dipropyl-8-cyclopentylxanthine (DPCPX) and 2, 4-dioxobenzo[g] pteridine (alloxazine) were dissolved in $100 \%$ DMSO as a $10 \mathrm{mM}$ stock solution. The final concentration of 
DMSO in the organ bath which had a total volume of $10 \mathrm{~mL}$, had no effect by itself on the aortic rings (Ansari et al., 2007b). Unless stated otherwise, all chemicals were of the highest grade available and were purchased from Sigma Chemicals (St. Louis, MO).

\section{Statistical Analysis}

The data were expressed as mean \pm SEM. Comparisons among different groups were analyzed by ANOVA (analysis of variance) followed by Tukey's multiple comparison test/Bonferroni's selected pair test. Comparison between two groups was assessed by unpaired t-test. A $p$ value of less than 0.05 was considered as the level of significance for all statistical tests. All the statistical analyses were performed using the Graph Pad Prism statistical package.

\section{Results}

\section{Systemic inflammation in control, allergic and adenosine aerosolized allergic mice}

Table 3.1 shows the multiplex cytokine profile in all the groups. Allergen challenge significantly increased plasma levels of inflammatory cytokines IL-5, IL-6, IL-13, and MCP-1 in sensitized (SEN) compared with control (CON) mice. Allergen-sensitized and challenged mice exposed to adenosine aerosol (SEN + AD) had the highest level of the pro-inflammatory cytokines including IL-1 $\beta$, IL-5, IL-13, MCP-1, MIP-1 $\alpha$ and TNF- $\alpha$ compared to other groups. Other cytokines in the panel were either undetectable or not different among the groups (data not shown). In addition, the cytokine profile was also studied in the $\mathrm{CON}+\mathrm{AD}$ group. Cytokine levels were not different between this group of animals aerosolized with adenosine compared with the CON group, suggesting that 
aerosolized adenosine in the absence of allergic inflammation had no effect on the inflammatory cytokine profile. CRP was also measured as an important systemic inflammatory marker. Plasma CRP levels significantly increased in the SEN compared with the CON group, with a further increase in the SEN + AD compared with the SEN group. Again, there was no difference between the $\mathrm{CON}$ and $\mathrm{CON}+\mathrm{AD}$ groups in $\mathrm{CRP}$ levels. These data show that sensitized mice challenged with allergen have systemic inflammation and that aerosolized adenosine further enhances the inflammation in these mice. Earlier studies from our laboratory have also shown no difference in the lung inflammation of control mice aerosolized with adenosine (Fan and Mustafa, 2002; Fan and Jamal Mustafa, 2006).

\section{Vascular reactivity in control, allergic and allergic + adenosine groups}

The aortic relaxation/contraction responses to adenosine were studied in each of the following four groups: $\mathrm{CON}, \mathrm{CON}+\mathrm{AD}, \mathrm{SEN}$, and $\mathrm{SEN}+\mathrm{AD}$. Organ bath data showed a concentration-dependent relaxation response to adenosine in the CON aorta (Fig. 3.1). The maximum relaxation produced by adenosine $\left(10^{-4} \mathrm{M}\right)$ was $21 \%$ and $25 \%$ in the CON and $\mathrm{CON}+\mathrm{AD}$ groups, respectively. There was no difference in the vasorelaxation between the $\mathrm{CON}$ and $\mathrm{CON}+\mathrm{AD}$ groups. Adenosine-induced aortic relaxations were impaired in the SEN aorta with a maximum relaxation of $7 \%$. The impairment of vasorelaxation response to adenosine observed in the SEN group was further aggravated in the SEN + AD aorta. Adenosine failed to elicit any relaxation response in the SEN + AD group; however, it produced a contractile response $(-5 \%)$ at higher doses. These data 
show that allergen sensitization and challenge altered the vascular reactivity, with adenosine aerosol further exacerbating it in allergic mice.

\section{Endothelial function and eNOS expression in control, allergic and allergic + adenosine groups}

The SEN and SEN + AD groups had significantly lower ( $\sim 50 \%$ relaxation) endothelial response to acetylcholine (Fig 3.2A) compared with that of the respective controls $(\sim 75 \%$ relaxation). Real-time PCR data also showed that the expression of eNOS in the aorta was significantly decreased in the SEN and SEN + AD groups compared with the Con group (Fig 3.2B). These data show that allergen challenge probably led to dysfunctional endothelium in the SEN and SEN + AD groups.

With the aerosolization of adenosine, it is difficult to assess the exact amount of adenosine reaching the lungs. However, the dose we have chosen is based on previous work from our laboratory (Fan and Mustafa, 2002; Fan et al., 2003; Fan and Jamal Mustafa, 2006). This dose of adenosine $(6 \mathrm{mg} / \mathrm{ml})$ has no systemic effects, which has been shown by the lack of any systemic inflammation, improvement in vascular reactivity, and endothelial response in the $\mathrm{CON}+\mathrm{AD}$ compared with the $\mathrm{CON}$ group. We also know that the half-life for adenosine is less than a minute. In fact, this was the reason why adenosine was chosen and not an adenosine analog. Most of the systemic effects of this dose would be gone within minutes. Therefore, it is unlikely that the effects of adenosine in this study are due to any hemodynamic changes in these animals. 
Adenosine receptors gene expression in control, allergic and allergic + adenosine groups

To gain further insight into the pattern of the expression of ARs and their involvement in the impairment of vasorelaxation observed in the SEN and SEN + AD groups, we first measured the aortic gene expression of all ARs before conducting organ bath experiments. Real-time PCR data showed that $\mathrm{A}_{1}$ (Fig 3.3A), $\mathrm{A}_{2 \mathrm{~A}}$ (Fig 3.3B) and $\mathrm{A}_{2 \mathrm{~B}} \mathrm{AR}$ (Fig 3.3C) expression was decreased in the SEN compared with the CON group, whereas $A_{3} A R$ expression remained unaffected (data not shown). The expression of $A_{1} A R$ increased significantly in the SEN $+\mathrm{AD}$ compared with the SEN group, whereas $\mathrm{A}_{2 \mathrm{~A}^{-}}$ and $\mathrm{A}_{2 \mathrm{~B}} \mathrm{ARs}$ decreased further; however, only the decrease in $\mathrm{A}_{2 \mathrm{~B}} \mathrm{AR}$ expression reached statistical significance. These data show that an alteration in AR expression is responsible for the impairment of vasorelaxation observed in the SEN and SEN + AD groups.

\section{Effect of specific A1 AR (DPCPX) and A2B AR (alloxazine) antagonists on vascular} reactivity in control, allergic and allergic + adenosine groups

Based on real-time PCR data, we used the $\mathrm{A}_{1} \mathrm{AR}$ antagonist to reverse the impairment observed in the SEN and SEN + AD groups since $A_{1} A R$ activation has been shown to cause vasoconstriction in earlier studies from our laboratory (Tawfik et al., 2005). Treatment of the aorta with the $\mathrm{A}_{1} \mathrm{AR}$ antagonist DPCPX $\left(10^{-5} \mathrm{M}\right)$ before concentrationresponse with adenosine resulted in a reversal of impaired vasorelaxation in the SEN and $\mathrm{SEN}+\mathrm{AD}$ groups (Fig 3.4). DPCPX shifted the CRC to adenosine toward the left in the SEN and SEN + AD groups, with the vasorelaxation observed in these groups being similar to the CON group (Fig 3.1). A concentration-dependent relaxation was seen in 
CON animals (CON and CON + AD), which was not affected by DPCPX except at the highest concentration of adenosine that was significant (data not shown).

We expected the inhibition of vasorelaxation by the blocking of $\mathrm{A}_{2 \mathrm{~B}} \mathrm{AR}$ since it is considered to be involved in the relaxation of the aorta (Grbovic and Radenkovic, 2003; Ansari et al., 2007b). The pretreatment of the aorta with the $A_{2 B} A R$ antagonist alloxazine $\left(10^{-4} \mathrm{M}\right)$ before $\mathrm{CRC}$ with adenosine resulted in the inhibition of vasorelaxation observed in the $\mathrm{CON}$ and $\mathrm{CON}+\mathrm{AD}$ aorta. Alloxazine shifted the $\mathrm{CRC}$ to adenosine toward the right, indicating a contraction in the $\mathrm{CON}$ and $\mathrm{CON}+\mathrm{AD}$ aorta (Fig 3.5A). Impaired vasorelaxation observed in the SEN and SEN + AD groups was also affected by prior treatment of the aorta with alloxazine (Fig 3.5B), with a further rightward shift of their respective CRCs. These data suggest that $\mathrm{A}_{1}$ - and $\mathrm{A}_{2 \mathrm{~B}} \mathrm{ARs}$ have a significant role in the impairment of vascular reactivity observed in the SEN and SEN + AD groups. DPCPX and alloxazine are selective inhibitors of $\mathrm{A}_{1^{-}}$and $\mathrm{A}_{2 \mathrm{~B}} \mathrm{AR}$, respectively, and have been used by others and our laboratory in earlier studies (Rose Meyer et al., 2003; Tawfik et al., 2005; Ansari et al., 2007b). 
Table 3.1: Systemic inflammation as assessed by levels of inflammatory cytokines in plasma of control (CON), adenosine aerosolized control (CON+AD), allergic (SEN) and adenosine aerosolized allergic (SEN+AD) mice; Values are expressed as mean \pm $\operatorname{SEM}(\mathbf{n}=5-8)$.

\begin{tabular}{|c|c|c|c|c|}
\hline $\begin{array}{l}\text { Inflammatory } \\
\text { marker }\end{array}$ & $\mathrm{CON}$ & $\mathrm{CON}+\mathrm{AD}$ & SEN & $\mathrm{SEN}+\mathrm{AD}$ \\
\hline IL-1 $\beta(\mathrm{pg} / \mathrm{ml})$ & $3.46 \pm 0.21$ & $3.29 \pm 0.09$ & $3.2 \pm 0.06$ & $24.08 \pm 10.32^{\$ \#}$ \\
\hline IL-5 (pg/ml) & $3.35 \pm 0.14$ & $4.19 \pm 0.67$ & $8.22 \pm 1.65^{\$}$ & $11.12 \pm 1.50^{\$}$ \\
\hline IL-6 (pg/ml) & $10.42 \pm 2.754$ & $12.90 \pm 3.79$ & $60.47 \pm 17.63^{\$}$ & $43.85 \pm 10.08^{\$}$ \\
\hline IL-13 (pg/ml) & $27.44 \pm 5.57$ & $33.19 \pm 7.60$ & $45.41 \pm 9.91^{\$}$ & $170.5 \pm 49.97^{\$ \#}$ \\
\hline MCP-1 (pg/ml) & $37.26 \pm 4.80$ & $39.91 \pm 4.59$ & $56.48 \pm 7.26^{\$}$ & $119.6 \pm 29.01^{\$ \#}$ \\
\hline MIP-1 $\alpha(\mathrm{pg} / \mathrm{ml})$ & $51.06 \pm 4.69$ & $54.36 \pm 8.13$ & $53.38 \pm 12.47$ & $165.0 \pm 31.57^{\$ \#}$ \\
\hline $\mathrm{TNF} \alpha(\mathrm{pg} / \mathrm{ml})$ & $6.66 \pm 1.03$ & $5.52 \pm 0.360$ & $6.25 \pm 0.230$ & $14.22 \pm 3.60^{\$ \#}$ \\
\hline $\begin{array}{l}\text { C-reactive } \\
\text { protein }(\mathrm{ng} / \mathrm{ml})\end{array}$ & $13.75 \pm 0.69$ & $14.51 \pm 0.67$ & $18.18 \pm 1.83^{\$}$ & $24.42 \pm 2.42^{\$ \#}$ \\
\hline
\end{tabular}

${ }^{\$} p<0.05$ as compared to $\mathrm{CON} ;{ }^{\#} p<0.05$ as compared to SEN 
Figure 3.1 Concentration-response curves for adenosine mediated relaxation/contraction in control (CON), adenosine aerosolized control (CON+AD), allergic (SEN) and adenosine aerosolized allergic (SEN+AD) mice. Values are expressed as mean $\pm \mathrm{SEM}$ $(n=8)$. On the ordinate, positive and negative values indicate relaxation and contraction, respectively. ${ }^{*} \mathrm{P}<0.05$ as compared to $\mathrm{CON} / \mathrm{CON}+\mathrm{AD} ;{ }^{*} \mathrm{P}<0.05$ as compared to $\mathrm{SEN}$.

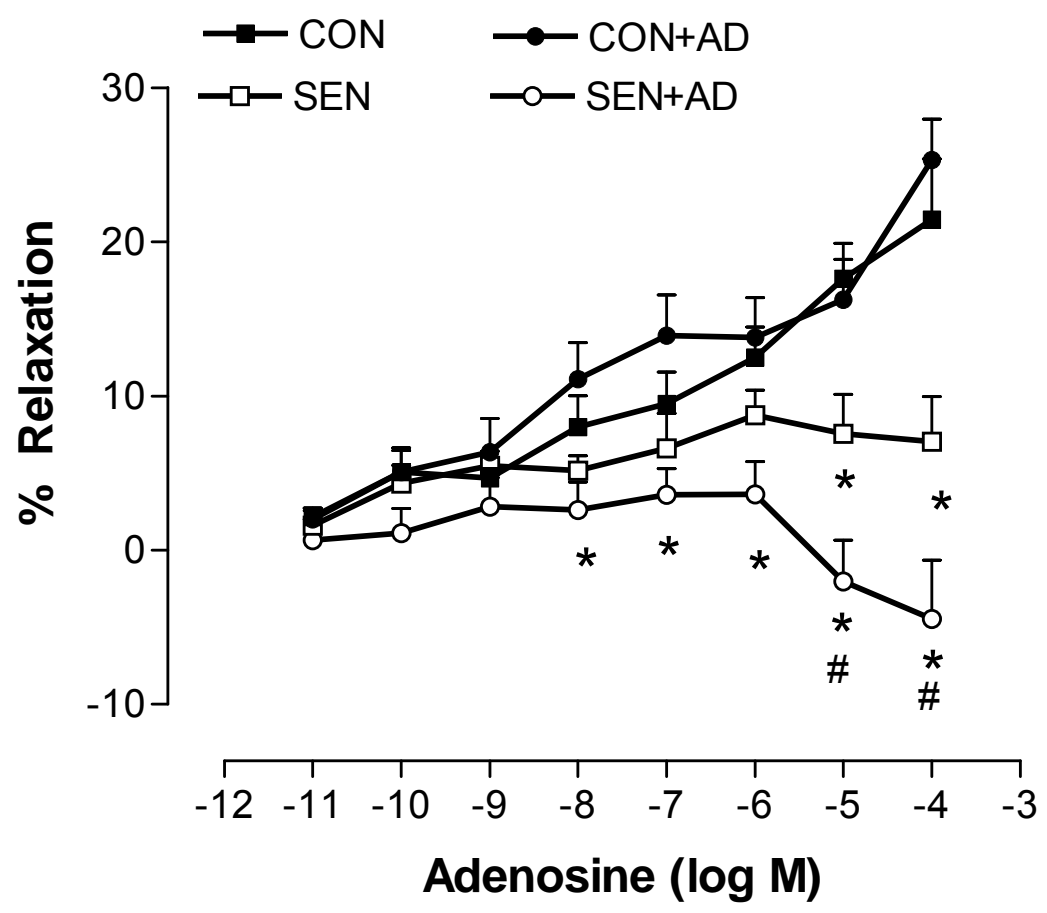


Figure 3.2 Endothelial responses to $\mathrm{ACh}$ in control (CON), adenosine aerosolized control (CON+AD), allergic (SEN) and adenosine aerosolized allergic (SEN+AD) mice. (A) Effect of acetylcholine $\left(10^{-7} \mathrm{M}\right)$ on phenylephrine (PE) precontracted aorta $(n=8)$; (B) Expression of eNOS by real time PCR $(n=4)$. For gene expression by comparative $\mathrm{C}_{\mathrm{T}}$ method using real time PCR, the CON group was used as the calibrator against which all other groups were compared. Values are expressed as mean \pm SEM. ${ }^{*} \mathrm{P}<0.05$ as compared to $\mathrm{CON} / \mathrm{CON}+\mathrm{AD}$.

(A)

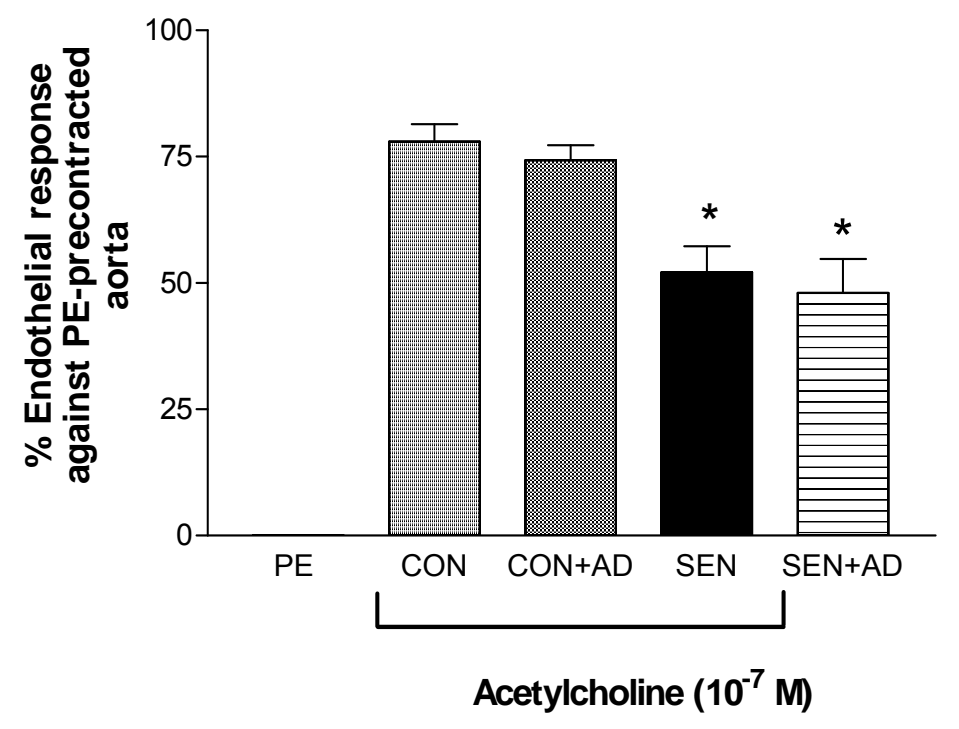

(B)

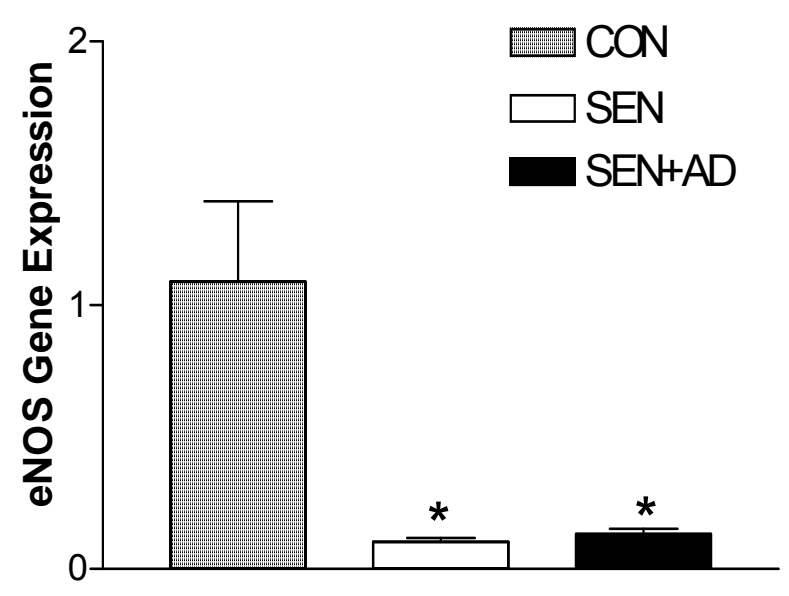


Figure 3.3 Expression of (A) $A_{1}$, (B) $A_{2 A}$, and (C) $A_{2 B}$ adenosine receptors by real time PCR in mice aorta of control (CON), allergic (SEN) and adenosine aerosolized allergic (SEN+AD) mice. For gene expression by comparative $\mathrm{C}_{\mathrm{T}}$ method using real time PCR, the CON group was used as the calibrator against which all other groups were compared. Values are expressed as mean $\pm \operatorname{SEM}(n=4) .{ }^{*} \mathrm{P}<0.05$ as compared to $\mathrm{CON} ;{ }^{\#} \mathrm{P}<0.05$ as compared to SEN.

(A)

(B)
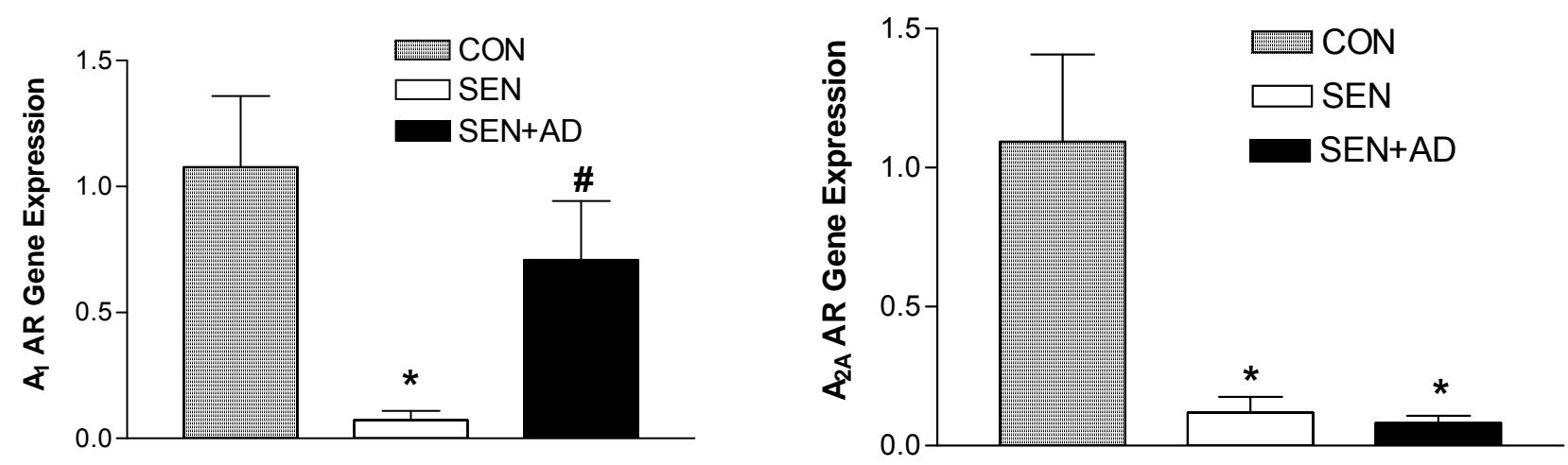

(C)

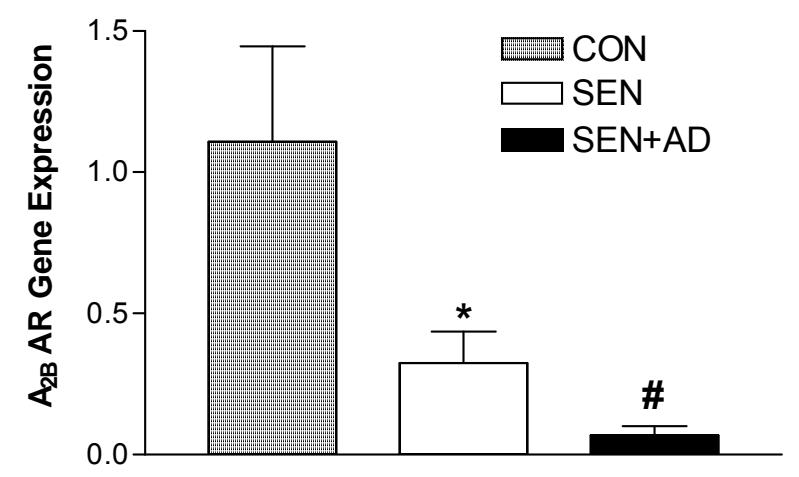


Figure 3.4 Effect of a specific $A_{1}$ AR antagonist, DPCPX $\left(10^{-5} \mathrm{M}\right)$ on adenosinemediated relaxation/contraction in aorta of allergic (SEN) and adenosine aerosolized allergic $(\mathrm{SEN}+\mathrm{AD})$ mice. Values are expressed as mean $\pm \operatorname{SEM}(n=8)$. On Y-axis, positive and negative values indicate relaxation and contraction respectively. ${ }^{*} \mathrm{P}<0.05$ as compared to SEN/SEN+AD.

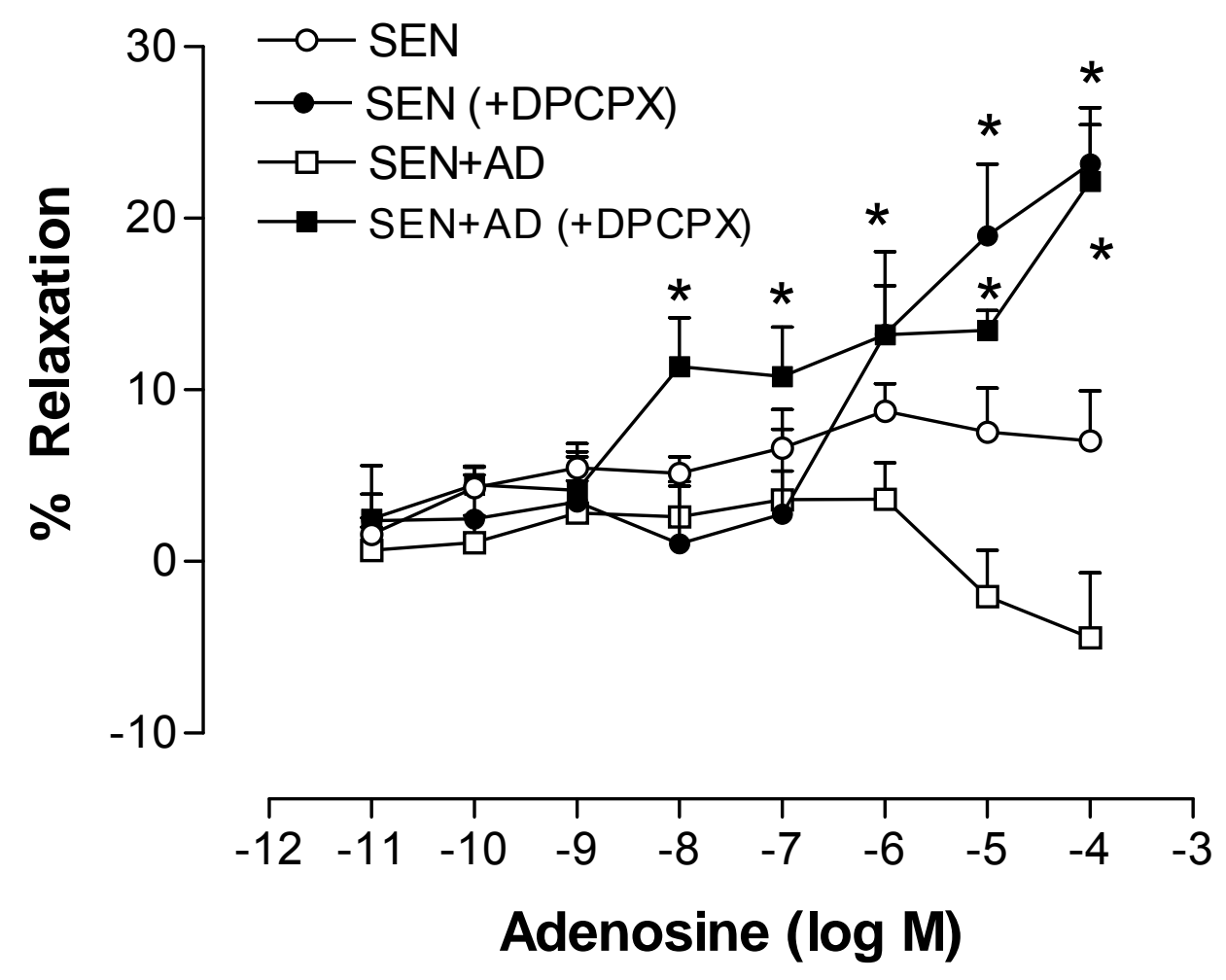


Figure 3.5 Effect of $A_{2 B} A R$ antagonist, Alloxazine $\left(10^{-4} \mathrm{M}\right)$ on adenosine-mediated relaxation/contraction in aorta of $(\mathrm{A})$ control mice $(\mathrm{CON})$; and $(\mathrm{B})$ allergic $(\mathrm{SEN})$ and adenosine aerosolized allergic (SEN+AD) mice. Values are expressed as mean $\pm \mathrm{SEM}$ $(n=4-8)$. On $\mathrm{Y}$-axis, positive and negative values indicate relaxation and contraction respectively. ${ }^{*} \mathrm{P}<0.05$ as compared to $\mathrm{CON} / \mathrm{CON}+\mathrm{AD}$; ${ }^{*} \mathrm{P}<0.05$ as compared to SEN/SEN+AD.

(A)

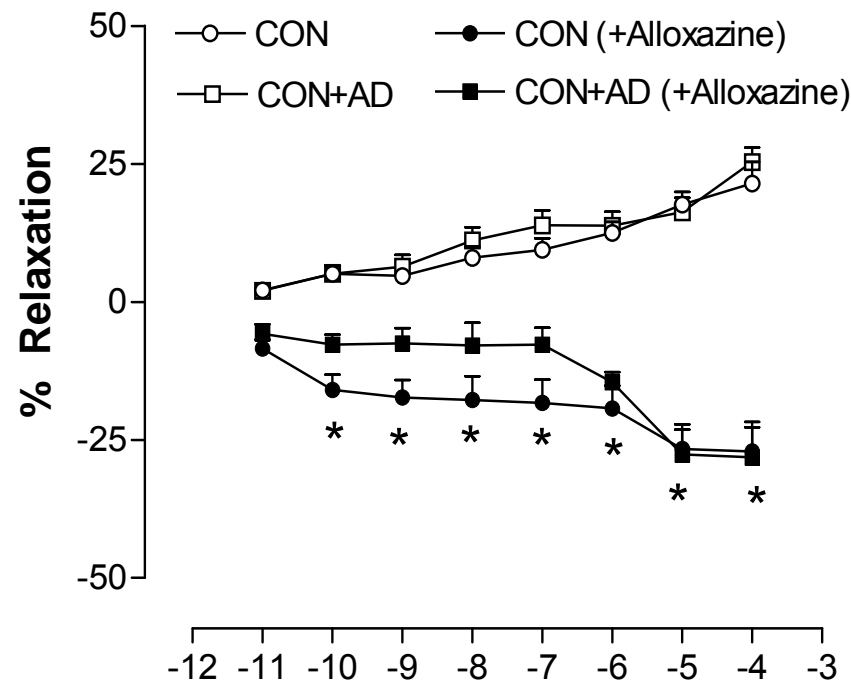

Adenosine $(\log \mathrm{M})$
(B)

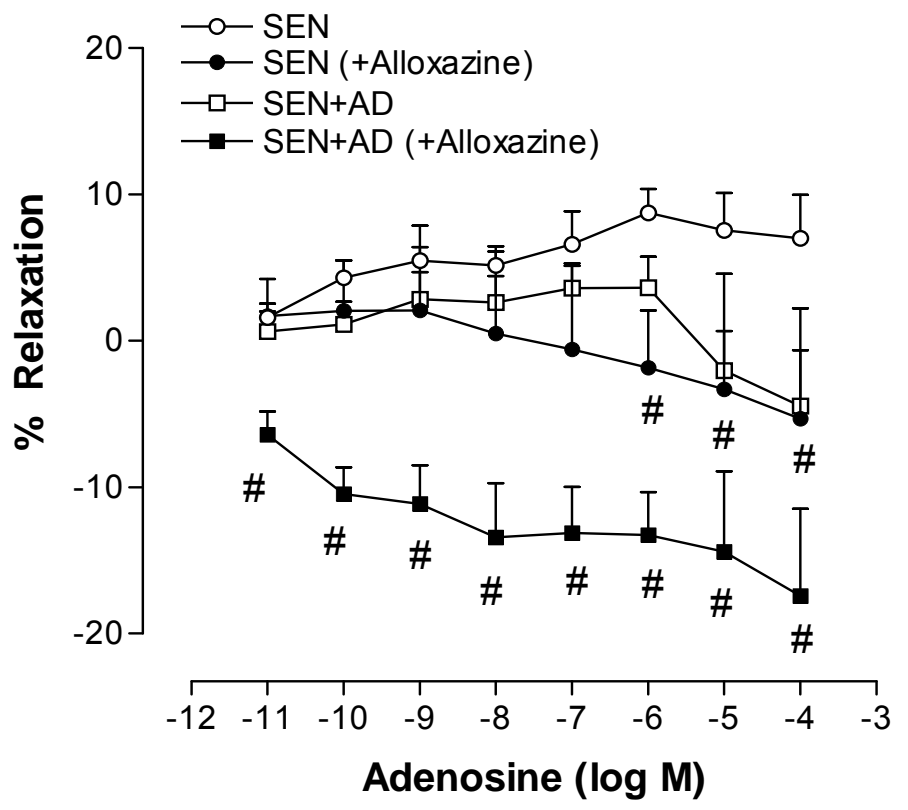




\section{Discussion}

The principal finding of the present study is that allergic mice had impaired vasorelaxation to adenosine and systemic inflammation, both of which were further aggravated after acute adenosine aerosol challenge in these mice. The AR expression profile was also altered in allergic mice and those aerosolized with adenosine after allergen challenge, which resulted in an impairment of vasorelaxation in these mice. Endothelium was found to be dysfunctional in both of these groups, since they had a decrease in aortic eNOS expression and endothelial relaxation to acetylcholine. The $\mathrm{A}_{1} \mathrm{AR}$ antagonist DPCPX attenuated the impairment in vasorelaxation observed in allergic mice and those subjected to adenosine aerosol after allergen challenge, whereas the $\mathrm{A}_{2 \mathrm{~B}} \mathrm{AR}$ antagonist alloxazine impaired the vasorelaxation further in these groups, supporting a role for $\mathrm{A}_{2 \mathrm{~B}} \mathrm{AR}$ in aortic relaxation.

Airway inflammation is associated with chronic elevations in lung adenosine levels that may be due to the release of adenosine among other inflammatory mediators from sensitized lung and activated leukocytes (Mann et al., 1986b; Mann et al., 1986a; Driver et al., 1993). This is also experimentally supported by chronically increasing lung adenosine levels by knocking out ADA, an enzyme responsible for adenosine breakdown or temporarily by the inhalation of adenosine aerosol, as in this study. Mice deficient in the ADA enzyme develop severe pulmonary inflammation, airway hyperreactivity, and airway remodeling in association with the elevated levels of adenosine in the lungs (Chunn et al., 2001; Blackburn and Kellems, 2005). Adenosine inhalation to the allergic lungs has also been shown to increase further airway responsiveness and inflammatory mediators (Driver et al., 1991; Fan and Mustafa, 2002; van den Berge et al., 2004; Fan 
and Jamal Mustafa, 2006), suggesting an important role for adenosine in the amplification of lung inflammation.

Systemic inflammation has also been reported earlier in humans with asthma and animal models of asthma (Jousilahti et al., 2002; Hazarika et al., 2004). Hazarika et al (Hazarika et al., 2007) recently showed an increase in neutrophils and eosinophils in the bronchoalveolar lavage and blood in a murine model of asthma. Systemic inflammatory markers have also been shown to be elevated in patients with asthma and in the allergic mouse model of asthma after the adenosine aerosol challenge performed earlier by our laboratory (Driver et al., 1991; Fan and Jamal Mustafa, 2006). We further extended these observations in the present study to investigate the cytokine profile in systemic circulation in our murine model of asthma. We found that allergic mice exposed to acute adenosine aerosol had increased systemic inflammation since several pro-inflammatory cytokines levels (IL-1 $\beta$, IL-5, IL-13, MCP-1, MIP-1 $\alpha$ and TNF- $\alpha$ ) were found to be the highest in this group. A recent report from this laboratory using this model of asthma has also shown increased activities of eosinophilic peroxidase, myeloperoxidase and $\beta$ hexosaminidase not only in the lung but also in the systemic circulation of allergic mice exposed to adenosine aerosol (Fan and Jamal Mustafa, 2006). Adenosine aerosol in humans with asthma has also been shown to cause increased release of neutrophil chemotactic factor in serum (Driver et al., 1991). These studies suggest that adenosine enhances the release of systemic inflammatory mediators from sensitized inflammatory cells. Our murine model of asthma, therefore, was appropriate to study the inflammatory effects of adenosine in combination with allergen on vascular reactivity. 
Asthma has been associated with an increased incidence of cardiovascular disorders (Drislane et al., 1987; Toren and Lindholm, 1996; Iribarren et al., 2004; Knoflach et al., 2005); however, there is little information regarding the role of asthmatic inflammation in the development of cardiovascular disease, especially in relation to the vascular effects of adenosine. In the present study, adenosine produced a concentrationdependent vasorelaxation in control mice, which was impaired in allergic mice. Vascular reactivity to adenosine was further altered in aorta of allergic mice that had received aerosolized adenosine. These data implicated a role for ARs in impairment of the vasorelaxation response in allergic mice and those challenged with adenosine aerosol after allergen. We have found that allergic animals subjected to theophylline inhalation before adenosine aerosol challenge had improved aortic vasorelaxation to the nonselective adenosine analog 5'-N-ethylcarboxamidoadenosine (NECA; unpublished data). This further supports a role for adenosine in impaired vasorelaxation.

As the direct effects of adenosine on hemodynamic parameters (blood pressure, oxygen saturations, and heart rate) were not assessed, it is possible that there could be adenosine-mediated effects on vasculature independent of inflammation in the allergic group (SEN + AD). The exact cause of why adenosine inhalation blunted aortic vasorelaxation to adenosine in sensitized and challenged mice, but not in control mice, is unclear. However, because the CON + AD group did not show a change in inflammatory markers and vasorelaxation to adenosine, it is likely that changes observed in the vasculature were due to allergen and adenosine in sensitized mice. Further studies are needed to completely assess the effects of adenosine on hemodynamic parameters in this model of asthma. 
To gain further insight into the AR responsible for the alteration in vascular reactivity, changes in ARs expression in allergen and adenosine-aerosolized allergic mice were measured. Real time PCR data showed a down-regulation of A1, A2A and A2B ARs in allergen-sensitized and challenged mice, the net result possibly being the impaired vasorelaxation observed in this group since it is known that A2A AR and A2B AR are involved in vasorelaxation (Grbovic and Radenkovic, 2003; Ansari et al., 2007b). A2A and $\mathrm{A}_{2 \mathrm{~B}} \mathrm{ARs}$ expression decreased further and the $\mathrm{A}_{1} \mathrm{AR}$ expression increased in allergic mice exposed to adenosine aerosol compared with allergic mice, leading to aortic contraction in this group. This effect could be due to the combined net result of an increase in the $\mathrm{A}_{1} \mathrm{AR}$ and further decrease in the expression of $\mathrm{A}_{2} \mathrm{ARs}$ since the former is involved in vasoconstriction and latter in vasorelaxation, as shown in earlier studies from others and our laboratory (Lewis et al., 1994; Tawfik et al., 2005; Ansari et al., 2007b).

Real-time PCR studies of ARs prompted us to look further into the roles of A1 AR and $\mathrm{A}_{2 \mathrm{~B}} \mathrm{AR}$ on vascular responses. The $\mathrm{A} 2 \mathrm{~B}$ AR antagonist alloxazine blocked the vasorelaxation in controls and caused a further impairment in allergic mice and those exposed to adenosine aerosol after allergen challenge, suggesting that adenosinemediated vasorelaxation could mainly be via the A2B AR. The A1 AR antagonist DPCPX reversed the impaired vasorelaxation in allergic mice and those exposed to adenosine aerosol after allergen challenge, suggesting that the A1 AR has an important role in vasoconstriction, especially when the vasorelaxant $\mathrm{A} 2 \mathrm{~B} \mathrm{AR}$ is downregulated. In an unpublished observation from our lab, pretreatment of aorta with the selective $A_{2 A}$ antagonist, SCH 58261, showed a decrease in NECA-induced aortic relaxation in control 
mice. However, SCH 58261 pretreatment did not have any significant effect on altered aortic relaxation to NECA observed in SEN and SEN + AD groups, suggesting a limited role in vascular reactivity for the $A_{2 A} A R$ in this particular experimental model. In conclusion, the data further support the involvement of $A_{1} A R$ in contraction and $A_{2 B} A R$ in relaxation of mice aorta in our model of allergic asthma.

The endothelium serves as an important regulator of vascular function and homeostasis by releasing mediators such as nitric oxide and prostaglandins (Mombouli and Vanhoutte, 1999); however, its role in relation to allergen exposure and adenosine challenge has not been explored. Allergen exposure probably contributed to the impairment in endothelial responses observed in allergic and adenosine aerosolized allergic mice since eNOS expression and vasorelaxation to acetylcholine was decreased equally in both of these groups. The exact cause of this dysfunction is not known but it could be possibly due to an increase in systemic inflammatory cytokines as they are reported to suppress eNOS and nitric oxide production (Cardaropoli et al., 2003; Li et al., 2004).

Endothelial dysfunction has been reported earlier after exposure to particulate matter in aorta of mice (Cozzi et al., 2006). Nurkiewicz et al (Nurkiewicz et al., 2004) have also shown impairment of endothelium-dependent arteriolar dilation in rat spinotrapezius muscle upon inhalation of particulate matter. Endothelial dysfunction caused by allergen exposure could be somewhat similar to that of particulate matter exposure in many ways. First, allergen particle size is in the same range as that of particulate matter. Second, particulate matter is known to cause lung inflammation, which spills over in systemic circulation, leading to endothelial dysfunction and other 
cardiovascular complications (Nurkiewicz et al., 2006; Bai et al., 2007). It is also reported to be associated with pulmonary as well as cardiovascular disorders (Schwarze et al., 2006).

The fact that endothelial responses to acetylcholine and eNOS expression were almost equal in allergic mice and those exposed to adenosine aerosol after allergen challenge, whereas vasorelaxation responses to adenosine were different between these groups, could be due to two reasons. First, it could be due to the further increase in several pro-inflammatory cytokines found in allergic mice exposed to adenosine aerosol as some of these cytokines are reported to directly alter vascular function (Tousoulis et al., 2006). Second, it could be due to the increased $A_{1} A R$ and decreased $A_{2 B} A R$ expression favoring aortic contraction in allergic mice exposed to adenosine aerosol. Further studies are required to delineate the role of each AR in alteration of vascular responses using specific AR knock-out mice.

In conclusion, our findings provide evidence for the first time that there are alterations in systemic parameters (inflammation, lower endothelial response and impaired vasorelaxation to adenosine) as a result of allergen exposure and adenosine aerosol challenge in sensitized mice. Therefore, therapeutic strategies designed to attenuate lung inflammation should also focus on the prevention of systemic inflammation and harmful systemic side effects. This strategy may be beneficial in lowering the incidence of adverse cardiovascular events in asthmatics. 


\title{
CHAPTER FOUR
}

\section{ROLE OF A $A_{2 A}$ ADENOSINE RECEPTORS IN THE REGULATION OF VASCULAR TONE}

\begin{abstract}
Adenosine mediates vascular responses through its 4 receptor subtypes: $A_{1}, A_{2 A}$, $\mathrm{A}_{2 \mathrm{~B}}$ and $\mathrm{A}_{3}$. In the murine aorta, the $\mathrm{A}_{2 \mathrm{~B}}$ receptor is believed to contribute to vasorelaxation while the role of the $\mathrm{A}_{2 \mathrm{~A}}$ receptors is not well documented. The current study was undertaken to investigate the role of $A_{2 A}$ receptors on aortic tone using $A_{2 A}$ adenosine receptor knock-out $\left(\mathrm{A}_{2 \mathrm{~A}} \mathrm{KO}\right)$ and corresponding wild-type $\left(\mathrm{A}_{2 \mathrm{~A}} \mathrm{WT}\right)$ mice for experiments along with suitable pharmacological tools. Experiments included organ bath studies and real time RT-PCR for adenosine receptor (AR) gene expression studies. Isolated aortic rings prepared from $\mathrm{A}_{2 \mathrm{~A}} \mathrm{WT}$ and $\mathrm{A}_{2 \mathrm{~A}} \mathrm{KO}$ mice were precontracted with phenylephrine $\left(10^{-7} \mathrm{M}\right)$ and concentration-response curves for adenosine analogs and selective agonists/antagonists were obtained. NECA (non-selective adenosine analog; $\left.\mathrm{EC}_{50}=6.78 \mu \mathrm{M}\right)$ and CGS $21680\left(\mathrm{~A}_{2 \mathrm{~A}} \mathrm{AR}\right.$ selective agonist; $\left.\mathrm{EC}_{50}=0.013 \mu \mathrm{M}\right)$ produced concentration-dependent relaxation $\left(25 \%\right.$ and $28 \%$ relaxation with NECA at $10^{-5} \mathrm{M}$ and CGS 21860 at $10^{-5} \mathrm{M}$, respectively) in $\mathrm{A}_{2 \mathrm{~A}} \mathrm{WT}$ aorta. In $\mathrm{A}_{2 \mathrm{~A}} \mathrm{KO}$ aorta, NECA $\left(\mathrm{EC}_{50}=\right.$ $0.075 \mu \mathrm{M})$ induced concentration-dependent contraction $\left(47 \%\right.$ at $10^{-6} \mathrm{M} ; \mathrm{p}<0.05$ compared to $\left.\mathrm{A}_{2 \mathrm{~A}} \mathrm{WT}\right)$ while CGS 21860 produced no response. $\mathrm{SCH} 58261\left(10^{-6} \mathrm{M} ; \mathrm{A}_{2 \mathrm{~A}} \mathrm{AR}\right.$ selective antagonist) abolished vasorelaxation in $\mathrm{A}_{2 \mathrm{~A}} \mathrm{WT}(\mathrm{p}<0.05)$ while no change was observed in $\mathrm{A}_{2 \mathrm{~A}} \mathrm{KO}$. When DPCPX $\left(10^{-5} \mathrm{M} ; \mathrm{A}_{1}\right.$ selective antagonist) was used, greater
\end{abstract}


vasorelaxation was observed in $\mathrm{A}_{2 \mathrm{~A}} \mathrm{WT}(50 \%$ vs. $25 \%$ in controls; $\mathrm{p}<0.05)$ while $\mathrm{A}_{2 \mathrm{~A}} \mathrm{KO}$ showed less contraction ( $5 \%$ vs. $47 \%$ in controls; $p<0.05$ ). Aortic endothelial function, determined by the response to acetylcholine, was significantly greater in WT compared to $\mathrm{KO}(66 \%$ in WT vs. $51 \%$ in $\mathrm{KO} ; \mathrm{p}<0.05)$. In conclusion, $\mathrm{A}_{2 \mathrm{~A}} \mathrm{AR} \mathrm{KO}$ mice had significantly lower aortic relaxation and endothelial function, suggesting that the $\mathrm{A}_{2 \mathrm{~A}} \mathrm{AR}$ plays an important role in vasorelaxation, probably with the endothelium playing a role.

\section{Introduction}

Adenosine is a ubiquitous endogenous nucleoside that has several physiological effects which are mediated through the four adenosine receptor (AR) subtypes, i.e., $A_{1}$, $\mathrm{A}_{2 \mathrm{~A}}, \mathrm{~A}_{2 \mathrm{~B}}$ and $\mathrm{A}_{3}$. Adenosine is known to modulate cardiac effects (Shryock and Belardinelli, 1997) and vascular responses. $A_{1}$ receptors are involved in lowering the heart rate (Evans et al., 1982; Belardinelli et al., 1989) and have a negative role in regulating blood pressure (Brown et al., 2006). All four receptors are involved in the regulation of vascular responses (Tabrizchi and Bedi, 2001). The vascular effects of adenosine differ according to the receptor subtype activated, the type of vascular bed involved and the species.

$\mathrm{A}_{1}$ and $\mathrm{A}_{3} \mathrm{ARs}$ have been shown to be involved in vasoconstriction (Shepherd et al., 1996; Talukder et al., 2002b; Hansen et al., 2003; Tawfik et al., 2005) whereas A2A and A2B ARs cause vasorelaxation (Lewis et al., 1994; Grbovic and Radenkovic, 2003; Ansari et al., 2007b). The $A_{2 A} A R$ was found to play a major role in the mediation of coronary vasodilation caused by adenosine and adenosine agonists (Belardinelli et al., 1998). In rat kidneys, the vasoconstrictor response is mediated via the activation of $A_{1}$ 
receptors (Rossi et al., 1988) and both $\mathrm{A}_{2 \mathrm{~A}}$ and $\mathrm{A}_{2 \mathrm{~B}}$ receptors are present in renal microvasculature, contributing differentially to vasodilation (Tang et al., 1999). In the pulmonary circulation, findings suggest that adenosine induced relaxation is mediated via the $A_{2 B}$ receptor via a nitric oxide independent mechanism (Haynes et al., 1995). It has been found that in mice, adenosine-induced aortic relaxation is predominantly mediated via $A_{2 B}$ adenosine receptor activation (Talukder et al., 2002a) and the response is endothelium-mediated through nitric oxide release (Ansari et al., 2007b). In the guinea pig, the $A_{2 A}$ receptor is involved in coronary vessel relaxation whereas the $A_{2 B}$ receptor is present predominately in the aorta (Martin et al., 1993; Shryock et al., 1998). Similarly, the vascular effect of adenosine in aorta and coronary vessels of rat has been reported to be mediated by both $\mathrm{A}_{2 \mathrm{~A}}$ and $\mathrm{A}_{2 \mathrm{~B}}$ receptors (Lewis et al., 1994; Lewis and Hourani, 1997).

The $\mathrm{A}_{2 \mathrm{~A}}$ receptor, though present in mouse aorta, has not been extensively studied in aortic relaxation and its role in the modulation of aortic vascular responses is unclear. This study was, therefore, undertaken to determine vascular responses mediated via the $\mathrm{A}_{2 \mathrm{~A}}$ receptor. Both pharmacological tools and genetically modified mice in which the $\mathrm{A}_{2 \mathrm{~A}}$ receptor was knocked out were used in the experiments. Isolated in vitro preparations of aortic rings from $\mathrm{A}_{2 \mathrm{~A}} \mathrm{WT}$ and $\mathrm{KO}$ mice were used to study the effects of $\mathrm{A}_{2 \mathrm{~A}}$ adenosine receptors on vascular smooth muscle tone using adenosine analogs (NECA), selective agonists (CGS 21860- $\mathrm{A}_{2 \mathrm{~A}}$ selective agonist; BAY 60-6583- $\mathrm{A}_{2 \mathrm{~B}}$ selective agonist) and antagonists (SCH5830- $\mathrm{A}_{2 \mathrm{~A}}$ selective antagonist; DPCPX-A $\mathrm{A}_{1}$ selective antagonist and alloxazine- $\mathrm{A}_{2 \mathrm{~B}}$ selective antagonist). Gene expression of the four adenosine receptor subtypes was also determined using aorta from both $\mathrm{A}_{2 \mathrm{~A}} \mathrm{WT}$ and $\mathrm{KO}$ mice in real time 
RT-PCR experiments. We hypothesized that adenosine $A_{2 A}$ receptors contributed to adenosine-mediated vascular relaxation, in part through an endothelium-dependent pathway. Our results indicate that the $\mathrm{A}_{2 \mathrm{~A}}$ receptor does contribute to aortic relaxation, more than previously thought.

\section{Materials and Methods}

\section{Mice}

$\mathrm{A}_{2 \mathrm{~A}} \mathrm{KO}$ and wild-type (WT) mice were obtained from the Institute of Experimental Medicine (C. Ledent, Universite Libre de Bruxelles, Brussels, Belgium). To homogenize the genetic background of the mice, the first-generation heterozygotes were bred for 14 generations on a CD1 (Charles River) outbred background, with selection for the mutant $\mathrm{A}_{2 \mathrm{~A}}$ gene at each generation by PCR. Fourteenth-generation heterozygotes were bred together to generate the $\mathrm{A}_{2 \mathrm{~A}} \mathrm{KO}$ and WT. Twelve to fourteen week old males and females were used for experiments. All experimental animals used in this study were under a protocol approved by the Institutional Animal Care and Use Committee of West Virginia University.

\section{Preparation of isolated mouse aorta and isometric force measurement}

Mice were sacrificed by anesthesia with pentabarbitol sodium $(65 \mathrm{mg} / \mathrm{kg}$, i.p.) followed by thoracotomy and removal of aorta that was then cut transversely into 3-4 $\mathrm{mm}$ rings. The rings were mounted vertically between two stainless steel wire hooks and then suspended in $10 \mathrm{~mL}$ organ baths containing Krebs-Henseleit buffer. The Krebs-Henseleit buffer (pH 7.4) containing $118 \mathrm{mM} \mathrm{NaCl}, 4.8 \mathrm{mM} \mathrm{KCl}, 1.2 \mathrm{mM} \mathrm{MgSO} 4,1.2 \mathrm{mM}$ 
$\mathrm{KH}_{2} \mathrm{PO}_{4}, 25 \mathrm{mM} \mathrm{NaHCO}, 11 \mathrm{mM}$ glucose and $2.5 \mathrm{mM} \mathrm{CaCl}_{2}$ was maintained at $37^{\circ} \mathrm{C}$ with continuous bubbling of $95 \% \mathrm{O}_{2}$ and $5 \% \mathrm{CO}_{2}$. For measurement of isometric force response, aortic rings were equilibrated for 90 min with a resting force of $1 \mathrm{~g}$ (Tawfik et al., 2005; Ansari et al., 2007b) and change of the bathing solution at 15 min interval. At the end of equilibration period, tissues were contracted with $50 \mathrm{mM} \mathrm{KCl}$ to check the contractility of individual aortic rings twice which were washed out with Krebs-Henseleit buffer. Aortic rings were then constricted with phenylephrine $\left(\mathrm{PE}, 10^{-7} \mathrm{M}\right)$ to obtain a steady contraction and changes in tension were monitored continuously with fixed range precision force transducer (TSD, $125 \mathrm{C}$, BIOPAC system) connected to the differential amplifier (DA 100B, BIOPAC system). The data were recorded using MP100, BIOPAC digital acquisition system and analyzed using Acknowledge 3.5.7 software (BIOPAC system).

\section{Contraction/relaxation experiments}

After equilibration, the responsiveness and stability of individual rings were checked by successive administration of submaximally effective concentration of PE $\left(10^{-7} \mathrm{M}\right)$. The integrity of the vascular endothelium was assessed pharmacologically by acetylcholine $\left(10^{-7} \mathrm{M}\right)$ to produce relaxation of PE pre-contracted rings. Aortic rings were then washed several times with Krebs-Henseleit solution, and allowed to equilibrate for 30 min before the experimental protocol began. In experiments where the involvement of endothelium was investigated, endothelium was removed mechanically prior to mounting in the bath, using a thin stainless steel wire to scrape the lumen of the aorta. 


\section{Experimental protocol}

The concentration-response curves (CRCs) for NECA $\left(10^{-11}-10^{-5} \mathrm{M}\right)$, CGS $21860\left(10^{-11}\right.$ $\left.10^{-5} \mathrm{M}\right)$ and BAY $60-6583\left(10^{-11}-10^{-5} \mathrm{M}\right)$ were run in parallel in aortic rings from $\mathrm{A}_{2 \mathrm{~A}} \mathrm{WT}$ and KO mice. In all cases, the drug was added to yield the next higher concentration only when the response to the earlier dose reached a steady state. In experiments where the effects of an antagonist were measured, it was added $30 \mathrm{~min}$ before contraction of the tissue with PE, and was present throughout the experiments. Contraction/relaxation responses were expressed as a percentage increase/decrease in the contraction with respect to $\mathrm{PE}$ (alone) in response to each concentration of agonist used.

\section{Real time PCR: $A_{1}, A_{2 A}, A_{2 B}$, and $A_{3} A R$ genes expression}

The aortic tissues were processed for total RNA isolation using the TRIzol reagent from Life Technologies/Invitrogen followed by DNase treatment to eliminate potential genomic DNA contamination as described recently by us (Ansari et al., 2007b). This was followed by conversion of $0.5 \mu \mathrm{g}$ of total RNA into cDNA using High Capacity cDNA archive kit (Applied Biosystems, Foster City, CA) in a total volume of 100 ul. Real-time PCR was then performed using an ABI PRISM 7300 Detection System (Applied Biosystems) using Taqman Universal Mastermix (Applied Biosystems, Branchburg, New Jersey) according to the instructions of the manufacturer. The reaction volume $(25 \mu \mathrm{L})$ consisted of $12.5 \mu \mathrm{L}$ of $2 \mathrm{X}$ Taqman Universal Mastermix, $1 \mu \mathrm{L}$ of cDNA, and $1.25 \mu \mathrm{L}$ of 20X FAM-labeled Taqman gene expression assay master mix solution. For the real-time PCR of the concerned genes (A1AR, A2AAR, A2BAR and $\left.A_{3} A R\right)$, the Taqman inventoried 
assays-on-demand gene expression products (Assay IDs for A3AR, A2BAR, A2AAR, and A1AR respectively are Mm00802076_m1; Mm00839292_m1; Mm00802075_m1 and Mm01308023_m1) were purchased from Applied Biosystems (Foster City, CA). 18S rRNA (Ribosomal RNA) was used as an endogenous control. The fold difference in expression of target cDNA was determined using the comparative $\mathrm{C}_{\mathrm{T}}$ method as described earlier (Livak and Schmittgen, 2001).

\section{Drugs used}

Acetylcholine, adenosine and phenylephrine were dissolved in distilled water. 1,3Dipropyl-8-cyclopentylxanthine (DPCPX), 2-p-(2-carboxyethyl)phenethylamino-5' Nethylcarboxamido adenosine hydrochloride (CGS 21680), SCH 58261, BAY 60-6583 and 2, 4-dioxobenzo[g]pteridine (alloxazine) were dissolved in 100\% DMSO as a $10 \mathrm{mM}$ stock solution. The final concentration of DMSO in organ bath $(10 \mathrm{~mL})$ had no effect by itself on the aortic rings (Ansari et al., 2007b). Unless stated otherwise, all chemicals were of the highest grade available and were purchased from Sigma Chemicals (St. Louis, MO).

\section{Statistical Analysis}

The data were expressed as mean \pm SEM. Comparisons among different groups were analyzed by ANOVA (analysis of variance) followed by Tukey's multiple comparison test/Bonferroni's selected pair test. Comparison between two groups was assessed by unpaired t-test. A $p$ value of less than 0.05 was considered as the level of significance for 
all statistical tests. All the statistical analyses were performed using Graph Pad Prism statistical package.

\section{Results}

\section{Response to NECA, CGS-21680 and BAY 60-6583}

The aortic relaxation/contraction responses to NECA, CGS-21680 and BAY 60-6583 were studied in $\mathrm{A}_{2 \mathrm{~A}} \mathrm{WT}$ and $\mathrm{KO}$ mice. Organ bath data showed a concentrationdependent contraction response to NECA, a non-selective adenosine analog, in $\mathrm{A}_{2 \mathrm{~A}} \mathrm{KO}$ aorta while a biphasic concentration response was observed in $\mathrm{A}_{2 \mathrm{~A}} \mathrm{WT}$ aorta (Fig. 4.1). The maximum contraction produced by NECA $\left(10^{-6} \mathrm{M}\right)$ was $45 \%$ in $\mathrm{KO}$ and maximum relaxation in WT was $25 \%\left(10^{-5} \mathrm{M}\right)$. CGS-21680, a selective $\mathrm{A}_{2 \mathrm{~A}}$ agonist, produced a concentration-dependent relaxation response in $\mathrm{A}_{2 \mathrm{~A}} \mathrm{WT}$ aorta (30\% at $10^{-5} \mathrm{M}$; Fig 4.2) while BAY 60-6583, a selective $A_{2 B}$ agonist, produced relaxation in both $A_{2 A}$ WT and KO aorta (38\% and $33 \%$ respectively at $10^{-5} \mathrm{M}$; Fig 4.3). These data show that $\mathrm{A}_{2 \mathrm{~A}} \mathrm{WT}$ and $\mathrm{KO}$ mice had different adenosine-mediated vascular-responses, with the $\mathrm{A}_{2 \mathrm{~A}}$ and $\mathrm{A}_{2 \mathrm{~B}}$ receptors eliciting relaxation.

\section{Endothelial function in $\mathrm{A}_{2 \mathrm{~A}} \mathrm{WT}$ and $\mathrm{KO}$ aorta}

$\mathrm{A}_{2 \mathrm{~A}} \mathrm{KO}$ mice had significantly lower ( $\sim 50 \%$ relaxation) aortic endothelial response to acetylcholine (Fig. 4.4 A) compared to the respective WT ( $\sim 75 \%$ relaxation in controls) group.

To determine the contribution of the endothelium to $A_{2 A}$ mediated relaxation, we next evaluated the CGS 21860 concentration-response relationship in $\mathrm{A}_{2 \mathrm{~A}}$ WT aortic tissue in which the endothelium had been scraped off (-E), as described in the method 
section. Removal of the endothelium abolished CGS-21860 induced relaxation (Fig 4.4 $\mathrm{B})$, suggesting the $\mathrm{A}_{2 \mathrm{~A}}$ receptor-mediated relaxation involved an endothelium dependent mechanism.

\section{Adenosine receptors gene expression in $\mathrm{A}_{2 \mathrm{~A}} \mathrm{WT}$ and $\mathrm{KO}$ mice}

To gain further insight into the pattern of adenosine receptors (AR) expression and their involvement in vasorelaxation observed in $\mathrm{A}_{2 \mathrm{~A}} \mathrm{WT}$ and $\mathrm{KO}$ groups, we measured aortic gene expression of all four ARs. Real time PCR data showed that there was no difference in receptor expression between $\mathrm{A}_{2 \mathrm{~A}} \mathrm{WT}$ and $\mathrm{KO}$ mice (Fig 4.5). These data suggest that the absence of the $A_{2 A}$ receptor contributed to lower NECA-mediated relaxation in $\mathrm{A}_{2 \mathrm{~A}} \mathrm{KO}$ mice.

\section{Effect of specific A1 AR (DPCPX), A2A AR (SCH 58261) and A2B AR (alloxazine) antagonists on vascular reactivity in $\mathrm{A}_{2 \mathrm{~A}} \mathrm{WT}$ and $\mathrm{KO}$ mice}

Treatment of aorta with the A1 AR antagonist, DPCPX $\left(10^{-5} \mathrm{M}\right.$; Fig. 4.6) prior to concentration response curve $(\mathrm{CRC})$ with NECA resulted in concentration-dependent vasorelaxation in $\mathrm{A}_{2 \mathrm{~A}} \mathrm{WT}$ aorta with maximum relaxation being $50 \%$ at $10^{-5} \mathrm{M}$ NECA. In $\mathrm{A}_{2 \mathrm{~A}} \mathrm{KO}$ aorta, DPCPX lowered the magnitude of contraction response, however no relaxation response was observed. The selective $\mathrm{A}_{2 \mathrm{~A}}$ antagonist, $\mathrm{SCH} 58261\left(10^{-6} \mathrm{M}\right)$ abolished NECA- and CGS 21860-mediated relaxation, respectively, in $\mathrm{A}_{2 \mathrm{~A}} \mathrm{WT}$ aorta (Fig 4.7 A and Fig 4.7 B) while it had no effect in $\mathrm{A}_{2 \mathrm{~A}} \mathrm{KO}$ tissue (data not shown).

We expected inhibition of vasorelaxation by blocking of A2B AR as it is considered to be involved in relaxation of aorta from mice (Grbovic and Radenkovic, 
2003; Ansari et al., 2007b). Pre-treatment of aorta with the A2B AR antagonist alloxazine $\left(10^{-5} \mathrm{M}\right)$ prior to NECA concentration-response resulted in inhibition of vasorelaxation observed in both $\mathrm{A}_{2 \mathrm{~A}} \mathrm{WT}$ and $\mathrm{KO}$ aorta (Fig 4.8 and Fig 4.9). 
Figure 4.1 Concentration-response curves for NECA-mediated relaxation/contraction in $\mathrm{A}_{2 \mathrm{~A}} \mathrm{WT}$ and $\mathrm{A}_{2 \mathrm{~A}} \mathrm{KO}$ mice. Values are expressed as mean $\pm \mathrm{SEM}(n=8)$. On the ordinate, positive and negative values indicate relaxation and contraction, respectively. ${ }^{*} \mathrm{P}<0.05$

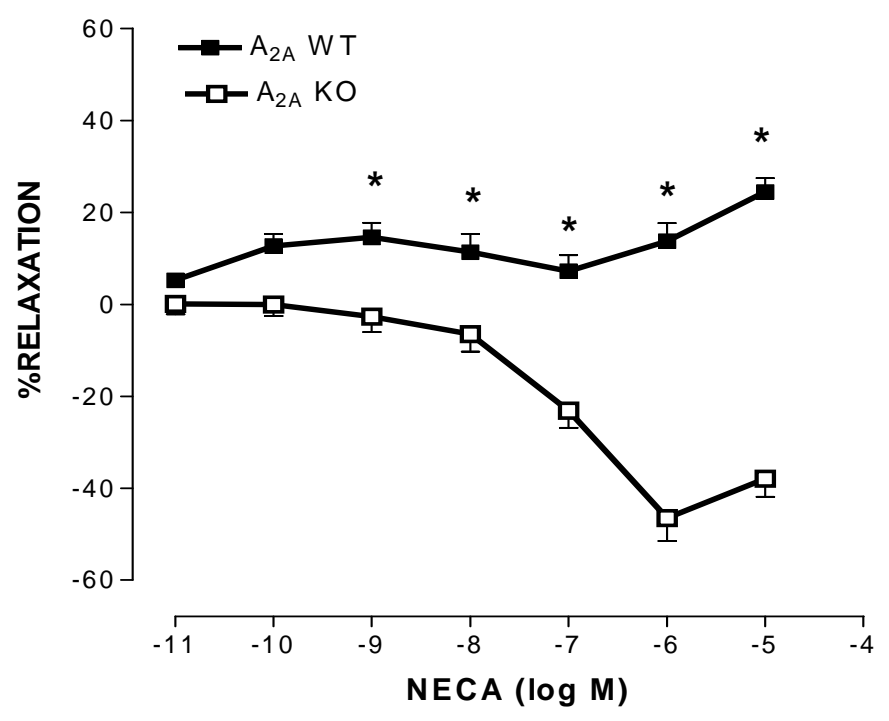


Figure 4.2 Concentration-response curves for CGS 21860-mediated relaxation/contraction in $\mathrm{A}_{2 \mathrm{~A}} \mathrm{WT}$ and $\mathrm{A}_{2 \mathrm{~A}} \mathrm{KO}$ mice. Values are expressed as mean $\pm \mathrm{SEM}$ $(n=8)$. On the ordinate, positive and negative values indicate relaxation and contraction, respectively. ${ }^{*} \mathrm{pP}<0.05$

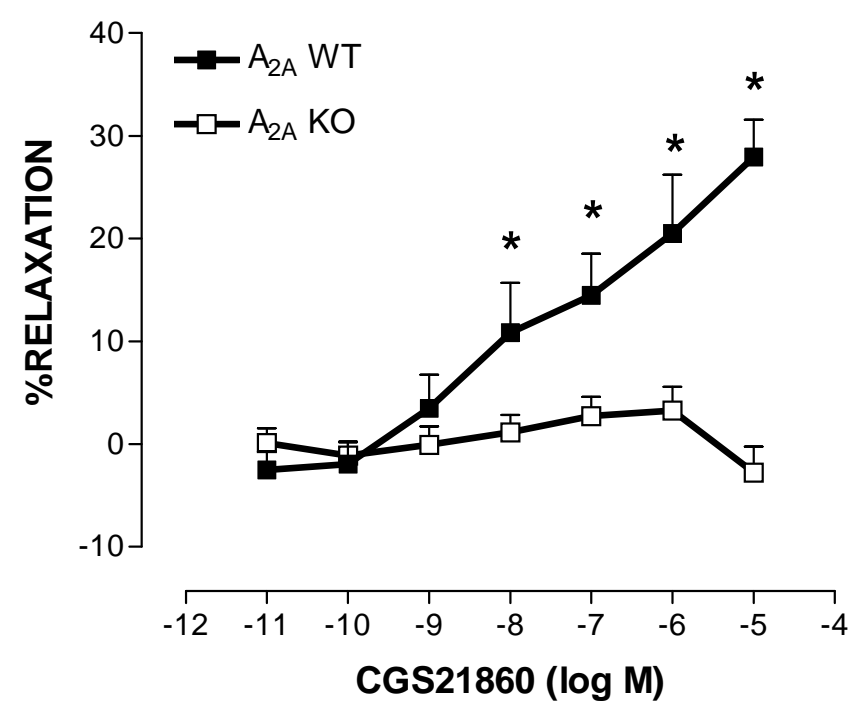


Figure 4.3 Concentration-response curves for BAY60-6583-mediated relaxation/contraction in $\mathrm{A}_{2 \mathrm{~A}} \mathrm{WT}$ and $\mathrm{A}_{2 \mathrm{~A}} \mathrm{KO}$ mice. Values are expressed as mean $\pm \mathrm{SEM}$ $(n=4)$. On the ordinate, positive and negative values indicate relaxation and contraction, respectively.

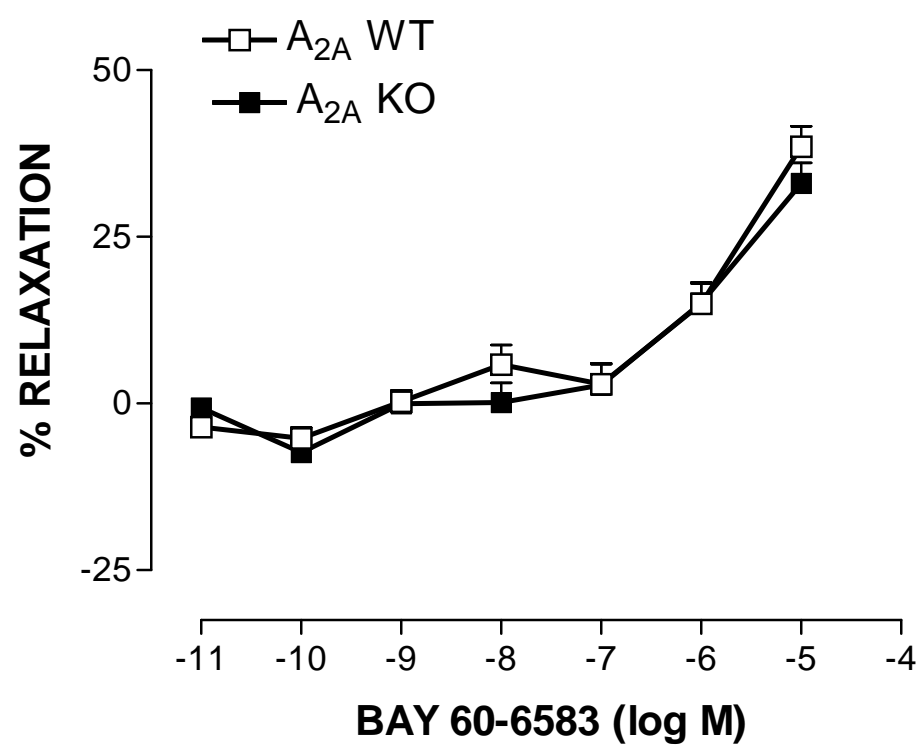


Figure 4.4 A) Endothelial response in $\mathrm{A}_{2 \mathrm{~A}} \mathrm{WT}(\sim 70 \%)$ and $\mathrm{A}_{2 \mathrm{~A}} \mathrm{KO}(\sim 50 \%)$ mice to acetylcholine. Values are expressed as mean $\pm \operatorname{SEM}(n=8) .{ }^{*} \mathrm{P}<0.05$ B) CGS 21860 response in $\mathrm{A}_{2 \mathrm{~A}} \mathrm{WT}$ endothelium denuded (-E) aorta ( $\mathrm{n}=4-8$ )

(A)

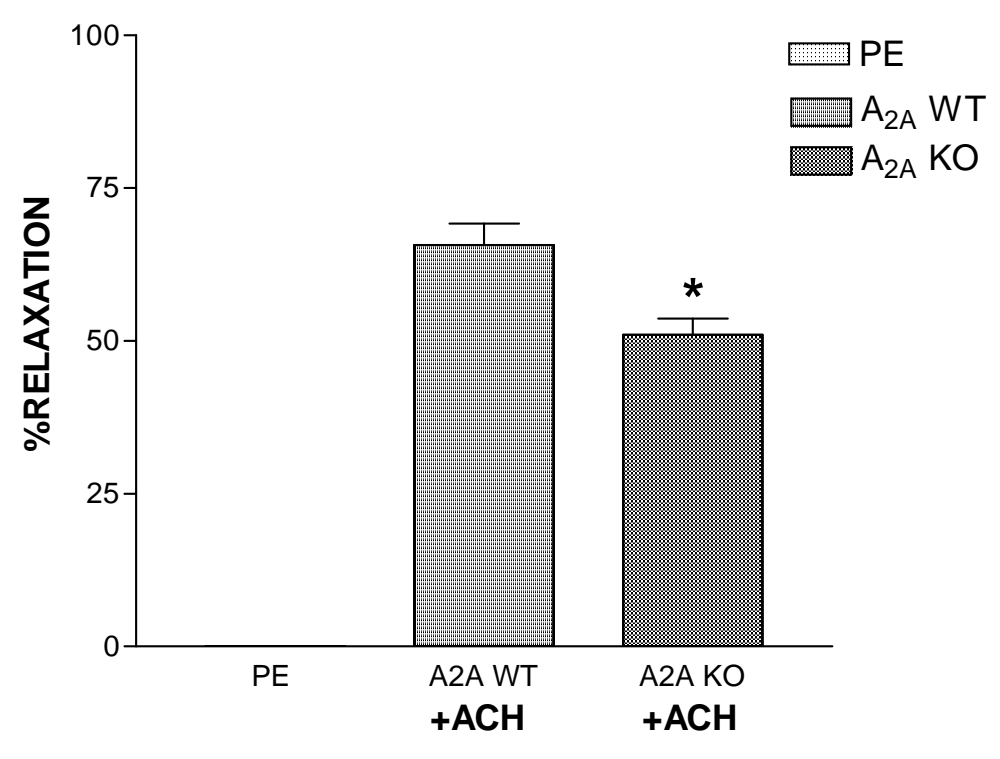

(B)

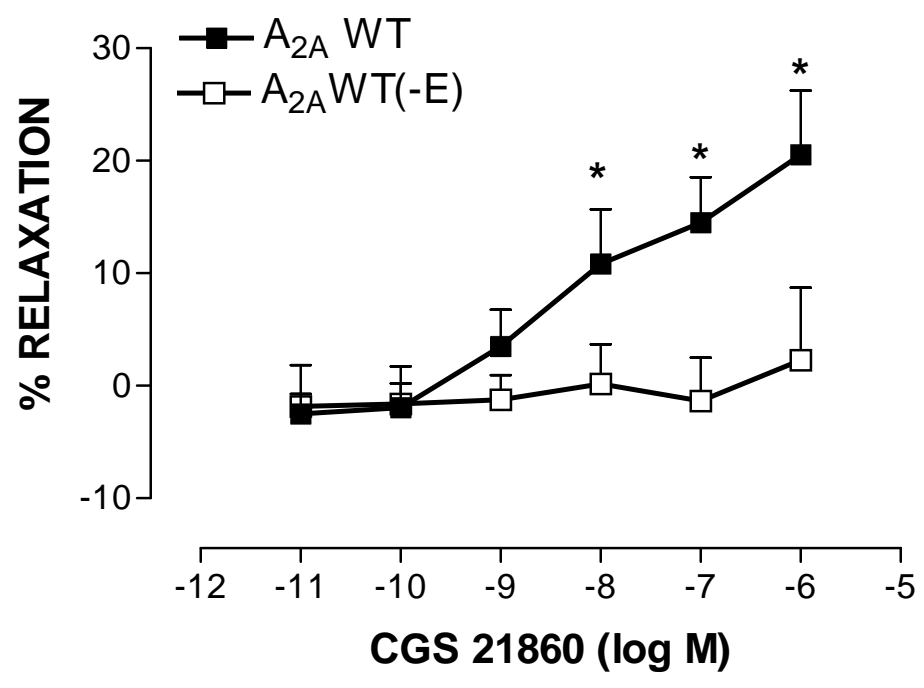


Figure 4.5 Adenosine receptor gene expression in $\mathrm{A}_{2 \mathrm{~A}} \mathrm{WT}$ and $\mathrm{A}_{2 \mathrm{~A}} \mathrm{KO}$ aorta. Values are expressed as mean \pm SEM $(n=8)$. There was no difference in the receptor expression levels between $\mathrm{KO}$ and WT mice, with the exception of the $\mathrm{A}_{2 \mathrm{~A}}$ receptor expression $(* \mathrm{P}<0.05)$

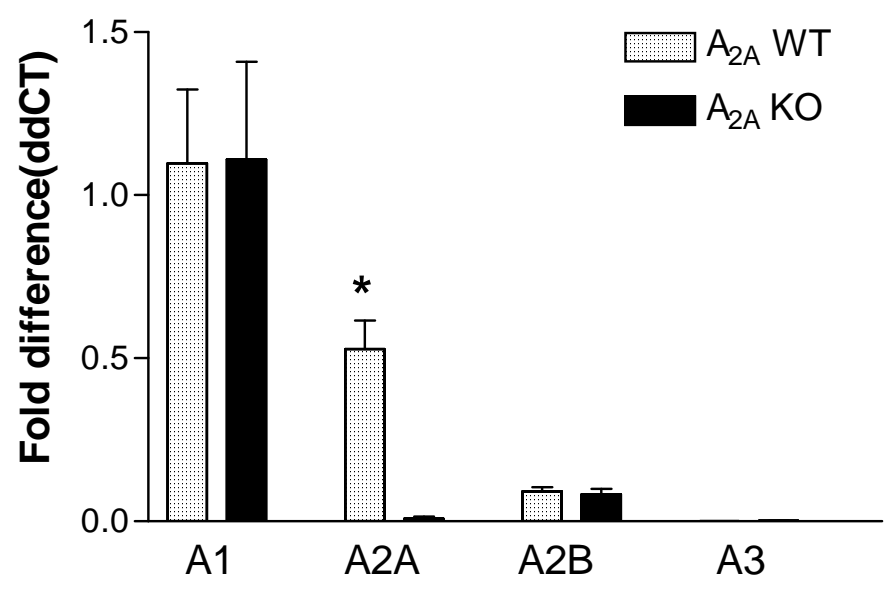


Figure 4.6 Effect of the selective $A_{1}$ antagonist DPCPX on NECA-mediated relaxation/contraction in $\mathrm{A}_{2 \mathrm{~A}} \mathrm{WT}$ and $\mathrm{A}_{2 \mathrm{~A}} \mathrm{KO}$ mice. Values are expressed as mean $\pm \mathrm{SEM}$ $(n=8)$. On the ordinate, positive and negative values indicate relaxation and contraction, respectively. Use of DPCPX produced significantly more relaxation in $\mathrm{A}_{2 \mathrm{~A}} \mathrm{WT}$ aorta $\left({ }^{*} \mathrm{P}<0.05\right)$ compared to the response in untreated WT tissues. In the $\mathrm{A}_{2 \mathrm{~A}} \mathrm{KO}$ tissues, DPCPX attenuated the contractile response ( $\# \mathrm{P}<0.05)$ compared to untreated $\mathrm{KO}$ tissues.

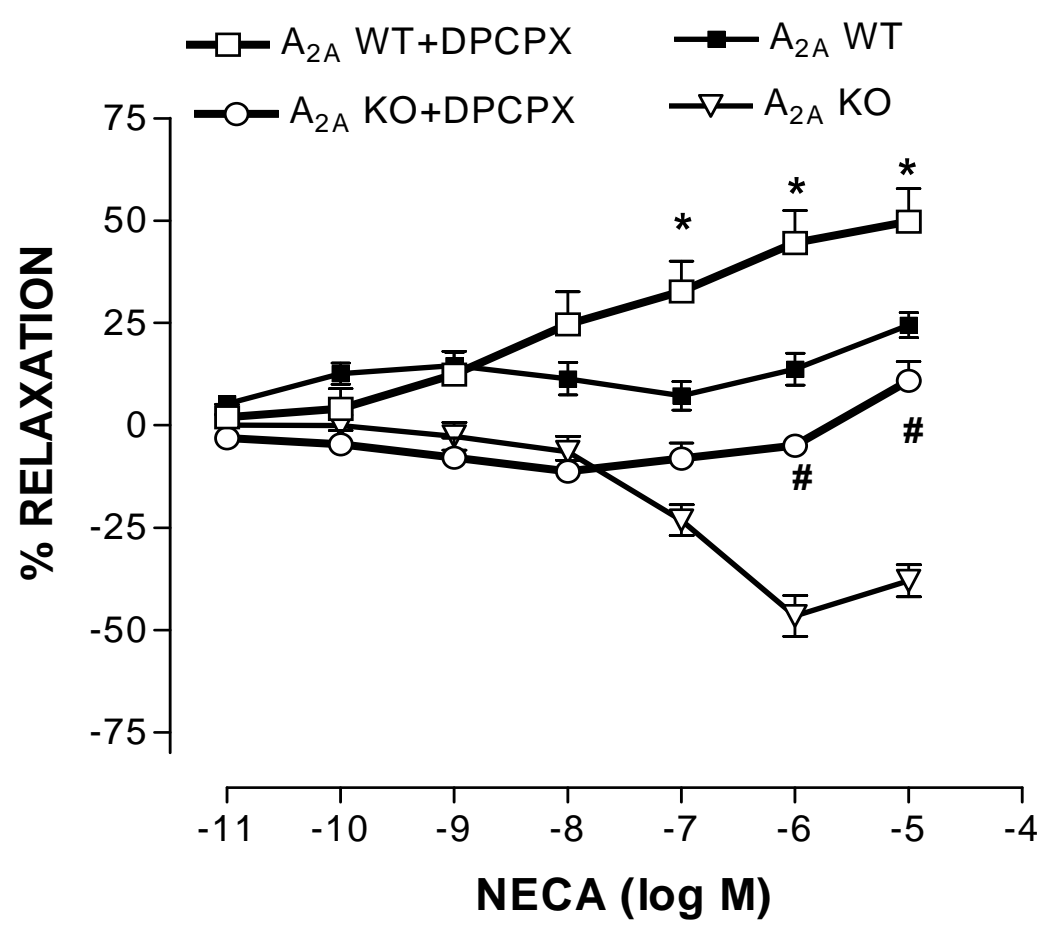


Figure 4.7 Effect of the selective $\mathrm{A}_{2 \mathrm{~A}}$ antagonist $\mathrm{SCH} 58261$ on (A) NECA- and (B) CGS 21860-mediated relaxation/contraction in $\mathrm{A}_{2 \mathrm{~A}} \mathrm{WT}$ aorta Values are expressed as mean \pm SEM $(n=8)$. On the ordinate, positive and negative values indicate relaxation and contraction, respectively. ${ }^{*} p<0.05$

(A)

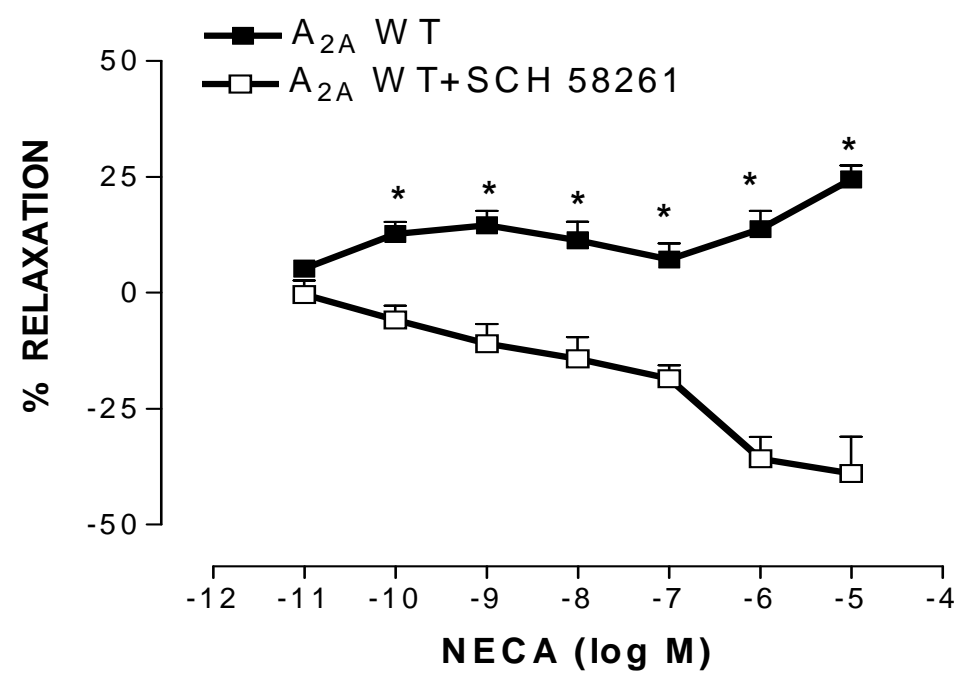

(B)

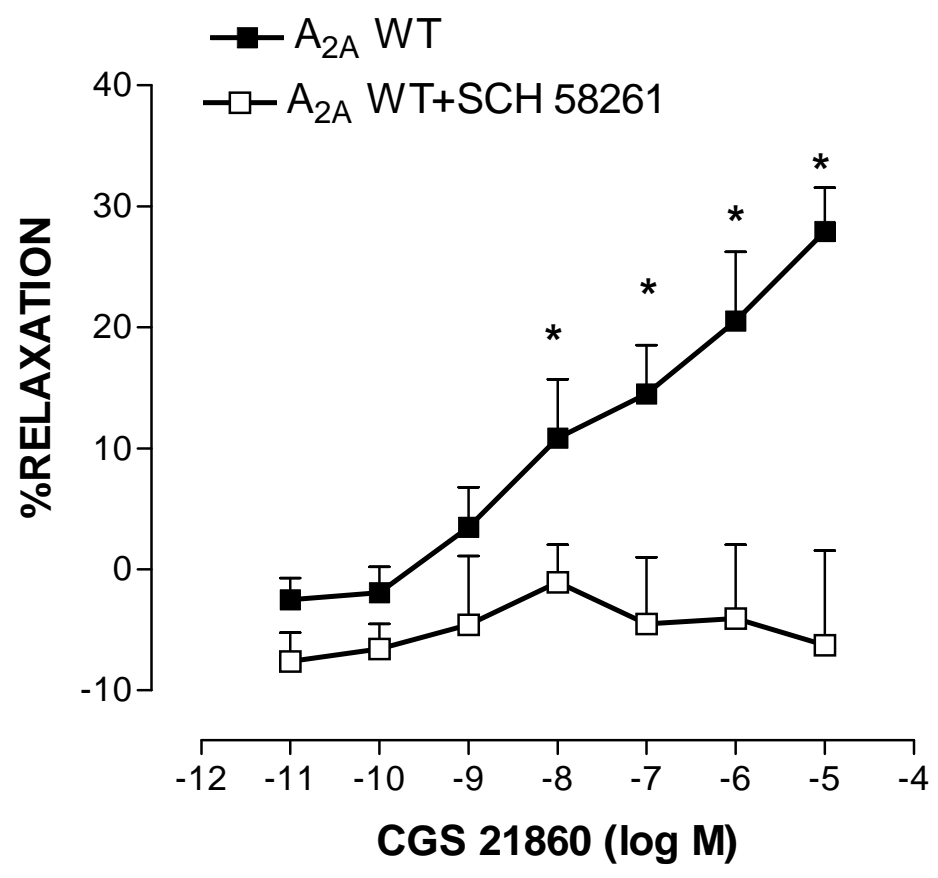


Figure 4.8 Effect of the selective $A_{2 B}$ antagonist alloxazine $\left(10^{-5} \mathrm{M}\right)$ on NECA-mediated relaxation/contraction in $\mathrm{A}_{2 \mathrm{~A}} \mathrm{WT}$ mice. Values are expressed as mean $\pm \operatorname{SEM}(n=8)$. On the ordinate, positive and negative values indicate relaxation and contraction, respectively. Use of alloxazine produced significantly less relaxation in $\mathrm{A}_{2 \mathrm{~A}} \mathrm{WT}$ aorta $(* \mathrm{P}<0.05)$ compared to the response in untreated WT tissues.

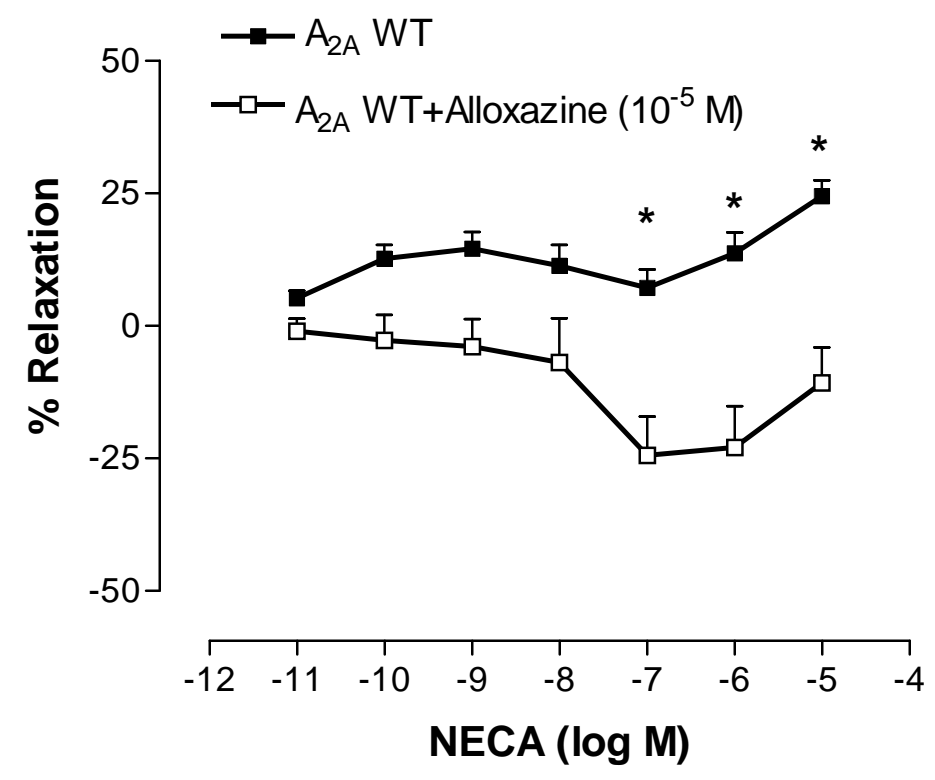


Figure 4.9 Effect of the selective $A_{2 B}$ antagonist alloxazine $\left(10^{-5} \mathrm{M}\right)$ on NECA-mediated relaxation/contraction in $\mathrm{A}_{2 \mathrm{~A}} \mathrm{KO}$ mice. Values are expressed as mean $\pm \mathrm{SEM}(n=8)$. On the ordinate, positive and negative values indicate relaxation and contraction, respectively. Use of alloxazine produced more contraction in $\mathrm{A}_{2 \mathrm{~A}} \mathrm{KO}$ aorta compared to the response in untreated $\mathrm{KO} * \mathrm{P}<0.05$

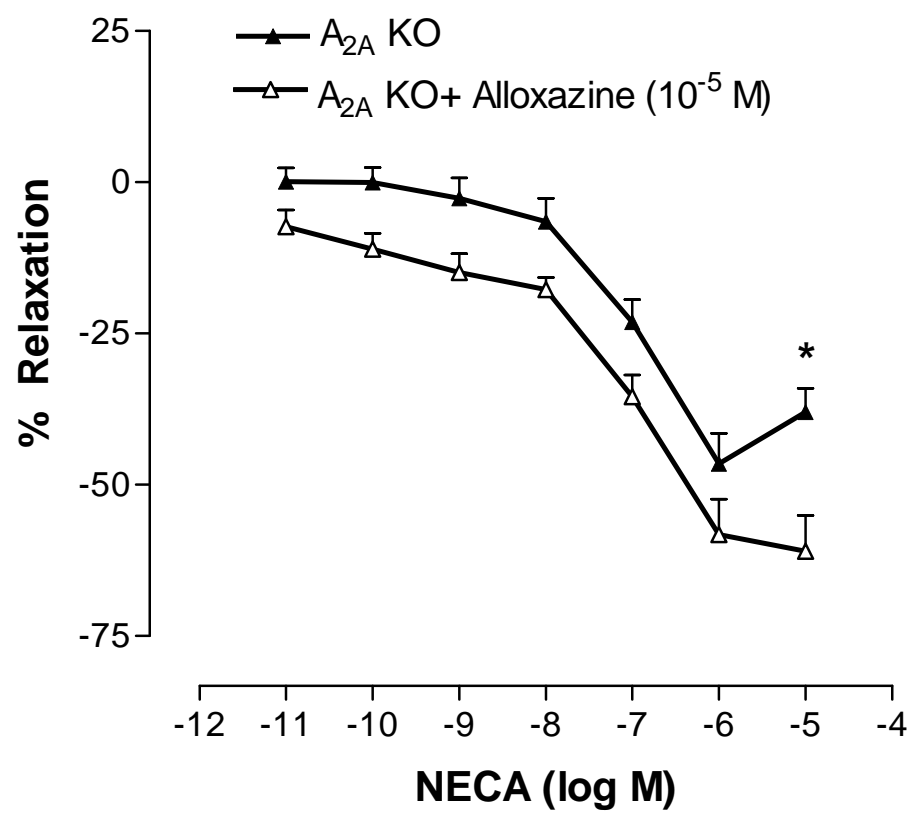




\section{Discussion}

The primary objective of this study was to determine whether $\mathrm{A}_{2 \mathrm{~A}}$ adenosine receptors play any role in aortic vasorelaxation in mice. Our principal finding is that $\mathrm{A}_{2 \mathrm{~A}} \mathrm{KO}$ mice had lowere aortic vasorelaxation and endothelium relaxation response compared to WT counterparts. The data indicates a role for endothelium-dependent $\mathrm{A}_{2 \mathrm{~A}}$ receptor mediated vasorelaxation in mouse aorta with the $\mathrm{A}_{2 \mathrm{~B}}$ receptor also contributing to aortic vascular relaxation.

The $A_{2}$ receptors are involved in adenosine-dependent vasorelaxation in almost all vascular beds studied, with the $\mathrm{A}_{2 \mathrm{~A}}$ and $\mathrm{A}_{2 \mathrm{~B}}$ contributing to the responses (Mustafa and Askar, 1985; Ramgopal MV et al., 1988; Abebe et al., 1994; Mustafa and Abebe, 1996; Ralevic and Burnstock, 1998). In mouse aorta, high affinity $A_{2 \mathrm{~A}}$ receptors are present but thier role in aortic vasorelaxation has not been established, while low-affinity $\mathrm{A}_{2 \mathrm{~B}}$ receptors are involved in relaxation (Talukder et al., 2002a; Ansari et al., 2007b). We found that NECA, a non-selective adenosine analog, produced a concentration-dependent contraction response in $\mathrm{A}_{2 \mathrm{~A}} \mathrm{KO}$ aorta. Biphasic concentration response was observed in the $A_{2 A}$ WT counterpart, suggesting the activation of more than one receptor. This data indicated the relaxation response produced by NECA partly involved activation of $A_{2 A}$ receptors as in the absence of these receptors, only contraction was observed.

We next used CGS 21680, which is a selective $\mathrm{A}_{2 \mathrm{~A}} \mathrm{AR}$ agonist, and found that $\mathrm{A}_{2 \mathrm{~A}} \mathrm{WT}$ aorta displayed concentration-dependent relaxation to CGS 21860, while the $\mathrm{A}_{2 \mathrm{~A}} \mathrm{KO}$ tissue did not respond. $\mathrm{SCH} 58360$, a selective $\mathrm{A}_{2 \mathrm{~A}} \mathrm{AR}$ antagonist was used to confirm the effects of CGS 21860 in activating the $A_{2 A}$ receptors. Relaxations to CGS 21860 and NECA in $\mathrm{A}_{2 \mathrm{~A}} \mathrm{WT}$ aorta were abolished with the use of the SCH compound, 
further confirming that the $\mathrm{A}_{2 \mathrm{~A}}$ receptor was involved in aortic relaxation. It should be noted that while NECA is capable of activating both $A_{2 A}$ and $A_{2 B}$ receptors, the $A_{2 B}$ receptor is low affinity and may be activated only at higher concentrations of NECA (Hussain and Mustafa, 1995; Hansen et al., 2003). The role of the $\mathrm{A}_{2 \mathrm{~B}}$ receptor thus could not be ruled out. The involvement of $A_{2 B}$ receptors was supported by the inability of NECA to produce relaxation in the presence of alloxazine, a selective $A_{2 B}$ antagonist, in $A_{2 \mathrm{~A}}$ WT aorta while greater contraction was observed in the $A_{2 \mathrm{~A}} \mathrm{KO}$ aorta. Interestingly, use of SCH 58360 in the NECA response produced steep concentration-dependent contraction in $A_{2 A}$ WT aorta, similar to NECA alone in $A_{2 A}$ KO tissue. The $A_{2 B}$ antagonist, alloxazine, produced contraction of a lower magnitude in $\mathrm{A}_{2 \mathrm{~A}} \mathrm{WT}$ aorta compared to KO. To further explore the possibility of the $\mathrm{A}_{2 \mathrm{~B}}$ receptor contributing to relaxation, concentration-response to a new and selective $\mathrm{A}_{2 \mathrm{~B}}$ agonist BAY 60-6583 was obtained. At lower concentrations, no response was seen in either $\mathrm{A}_{2 \mathrm{~A}} \mathrm{WT}$ or $\mathrm{KO}$ aorta while at higher concentrations $\left(10^{-6}\right.$ and $\left.10^{-5} \mathrm{M}\right)$ relaxation was observed in both $\mathrm{A}_{2 \mathrm{~A}}$ WT and $\mathrm{KO}$ tissues.

The $A_{1}$ receptor is believed to mediate contraction in the mouse aorta (Prentice et al., 2001; Tawfik et al., 2005). NECA has also been reported to cause contraction in isolated carotid rings from both $\mathrm{A}_{2 \mathrm{~A}}$ receptor-knockout and wild-type mice and this effect was eliminated by the selective $\mathrm{A}_{1}$ receptor antagonist DPCPX (Prentice et al., 2002). We found that incubation of tissues with DPCPX prior to obtaining NECA concentration-response produced a concentration-dependent relaxation response in $\mathrm{A}_{2 \mathrm{~A}} \mathrm{WT}$ aorta and abolished the biphasic response seen with NECA alone. DPCPX also lowered the magnitude of NECA-mediated contraction observed in $\mathrm{A}_{2 \mathrm{~A}} \mathrm{KO}$. DPCPX is a 
highly selective $\mathrm{A}_{1}$ receptor antagonist with a $K_{\mathrm{i}}$ of $3.9 \mathrm{nM}$ compared with 130 for $\mathrm{A}_{2 \mathrm{~A}}$, 1,000 for $\mathrm{A}_{2 \mathrm{~B}}$, and 4,000 $\mathrm{nM}$ for $\mathrm{A}_{3}$ (Klotz et al., 1998). Our data thus confirms that the $\mathrm{A}_{1}$ receptor mediated contraction in the $\mathrm{A}_{2 \mathrm{~A}} \mathrm{WT}$ and $\mathrm{KO}$ aorta.

The endothelium has been shown to play an important role in adenosine mediated relaxation as well as contraction and various studies have reported effects that are either completely endothelium-dependent/independent, or partially endothelium-dependent in different isolated vessels (Rubanyi and Vanhoutte, 1985; Newman et al., 1988; Yen et al., 1988; Ansari et al., 2007b; Ansari et al., 2007a). Gauging the endothelial response in $\mathrm{A}_{2 \mathrm{~A}} \mathrm{WT}$ and $\mathrm{KO}$ aorta was thus important. We found the endothelial response to acetylcholine was significantly lower in $\mathrm{A}_{2 \mathrm{~A}} \mathrm{KO}$ aorta than WT. This prompted us to further study the effect of the endothelium in the adenosine-mediated relaxation that was observed. Mechanical removal of the endothelium totally abolished the endotheliumdependent relaxation response to acetylcholine and completely attenuated CGS 21860induced relaxation. This data provides evidence for the first time that $\mathrm{A}_{2 \mathrm{~A}}$ mediated aortic vasorelaxation is endothelium dependent as CGS 21860 is a selective $\mathrm{A}_{2 \mathrm{~A}}$ agonist.

Studies have reported the up-regulation of the $\mathrm{A}_{2 \mathrm{~B}}$ receptor in coronary arteries of $\mathrm{A}_{2 \mathrm{~A}} \mathrm{KO}$ mice as a possible compensatory mechanism (Teng et al., 2008). To determine the effect of knocking out the $\mathrm{A}_{2 \mathrm{~A}}$ receptor on the expression of the other adenosine receptors in the aorta, we studied the adenosine receptor gene expression profile in isolated aorta. These studies showed that there was no difference in the aortic expression of the four adenosine receptors with the exception of the $A_{2 \mathrm{~A}}$ receptor which was absent in the $\mathrm{A}_{2 \mathrm{~A}} \mathrm{KO}$ as expected. Additionally, this supports our functional data in which we 
found the selective $\mathrm{A}_{2 \mathrm{~B}}$ receptor agonist $\mathrm{BAY}$ 60-6583 produced relaxation in both $\mathrm{A}_{2 \mathrm{~A}} \mathrm{WT}$ and $\mathrm{KO}$ aorta that was not different.

In conclusion, the data provided here indicate a role for $\mathrm{A}_{2 \mathrm{~A}}$ receptors in mediating vascular relaxation in mouse aorta. The $\mathrm{A}_{2 \mathrm{~B}}$ receptors also contribute to aortic relaxation, while the $A_{1}$ receptor mediates contraction. Finally, $A_{2 A}$ mediated relaxation appears to be completely endothelium-dependent. The exact mechanism and signaling pathways of this endothelium-dependent response remains to be elucidated. 


\title{
CHAPTER FIVE
}

\section{EVIDENCE FOR THE ROLE OF THE A ADENOSINE RECEPTOR IN ALTERED VASCULAR RESPONSES AND INFLAMMATION IN ALLERGIC MICE}

\begin{abstract}
Poor lung function and respiratory disorders such as asthma have a positive correlation with the development of adverse cardiovascular events. We hypothesize that asthmatic lung inflammation has a systemic component and alters vascular responses where adenosine $(A D)$ plays an important role through $A_{1}$ adenosine receptors $\left(A_{1} A R\right)$. This study used a murine model of allergic asthma to investigate the effects of aerosolized $\mathrm{AD}$ to elevate lung $\mathrm{AD}$ levels, on vascular reactivity and inflammation in genetically modified mice, in which the $A_{1} A R$ was deleted $\left(A_{1} K O\right)$ and corresponding wild type mice $\left(\mathrm{A}_{1} \mathrm{WT}\right)$. Both $\mathrm{A}_{1} \mathrm{WT}$ and $\mathrm{A}_{1} \mathrm{KO}$ mice were divided into 3 experimental groups: Control (CON), allergen sensitized and challenged (SEN), and SEN+ aerosolized AD (SEN+AD). Animals were sensitized with ragweed $(200 \mu$ g, i.p.) on days 1 and 6, followed by $1 \%$ ragweed aerosol challenges through days 11 to 13 . On day 14 , SEN+AD groups received a single $\mathrm{AD}$ aerosol challenge $(6 \mathrm{mg} / \mathrm{ml})$ for $2 \mathrm{~min}$, followed by collection of aorta and plasma on day 15. Organ bath experiments showed concentrationdependent aortic relaxation to NECA, a non-selective adenosine analog in $\mathrm{A}_{1} \mathrm{WT} \mathrm{CON}$, which was impaired in $\mathrm{A}_{1} \mathrm{WT}$ SEN and $\mathrm{A}_{1} \mathrm{WT} \mathrm{SEN}+\mathrm{AD}$. All 3 groups of $\mathrm{A}_{1} \mathrm{KO}$ mice showed concentration dependent relaxation to NECA, with no difference observed
\end{abstract}


between $\mathrm{A}_{1} \mathrm{KO} \mathrm{CON}, \mathrm{A}_{1} \mathrm{KO} \mathrm{SEN}$ and $\mathrm{A}_{1} \mathrm{KO} \mathrm{SEN}+\mathrm{AD}$. Allergen challenge caused systemic inflammation in allergic $\mathrm{A}_{1} \mathrm{WT}$ mice with $\mathrm{AD}$ aerosol further enhancing it as determined by inflammatory cytokines profile in plasma whereas inflammation was absent in all 3 groups of $\mathrm{A}_{1} \mathrm{KO}$ mice. $\mathrm{A}_{1} \mathrm{WT}$ allergic mice also had significantly higher airway hyper-responsiveness $\left(\mathrm{P}<0.05\right.$, compared to WT $\mathrm{CON}$ and all $\mathrm{A}_{1} \mathrm{KO}$ groups $)$ to NECA, measured as Penh (enhanced pause). In conclusion, allergic $\mathrm{A}_{1} \mathrm{WT}$ mice showed altered vascular reactivity, increased airway responsiveness and systemic inflammation, with $\mathrm{AD}$ aerosol further exacerbating all these effects with $\mathrm{A}_{1} \mathrm{KO}$ mice lacking these effects. These data suggest that $\mathrm{A}_{1} \mathrm{AR}$ plays an important pro- inflammatory role systemically and is responsible for altered vasoreactivity in this model of asthma.

\section{Introduction}

Asthma, a chronic lung disease, is characterized by airway hyperreactivity and inflammation which result in bronchoconstriction and poor ventilation. Evidence has increasingly implicated adenosine in the pathophysiology of asthma (Spicuzza et al., 2006). Increases in adenosine levels correspond to increased airway inflammation and tissue damage (Driver et al., 1993). A hallmark study done in the early nineteen-eighties showed inhaled adenosine to be a potent bronchoconstrictor in asthmatics as opposed to normal subjects who showed no response (Cushley et al., 1984). Genetically modified mice in which adenosine deaminase (ADA), the enzyme that breaks down adenosine, was knocked out could not survive without exogenous administration of ADA and had severe pulmonary inflammation, airway hyper-reactivity and airway remodeling (Chunn et al., 
2001; Blackburn and Kellems, 2005), indicating a strong correlation between chronic elevation of adenosine levels and increased lung inflammation.

Impaired lung function is a risk factor for cardiovascular disease (Tockman et al., 1995) and many epidemiological studies have reported that people suffering from chronic respiratory diseases, including asthma, have a higher incidence of cardiovascular diseases (Drislane et al., 1987; Toren and Lindholm, 1996; Iribarren et al., 2004; Knoflach et al., 2005; Schanen et al., 2005). There is an association between atherosclerosis and stroke with reactive airway diseases. Adult-onset asthma is associated with increased carotid atherosclerosis in women (Onufrak et al., 2007) and subjects who had bronchial hyperresponsiveness to methacholine demonstrated increased carotid intima-media thickness (Zureik et al., 2004). Systemic inflammation in these patients, believed to be a consequence of airway inflammation (Jousilahti et al., 2002; Nadeem et al., 2003), may be one of the reasons for altered cardiovascular parameters observed (Gan et al., 2004). Studies done in animal models of allergic asthma have also reported enhanced systemic inflammation, myocardial ischemia-reperfusion injury and neutrophil recruitment to the myocardium (Hazarika et al., 2004, 2007). A recent study from our lab (Ponnoth et al., 2008) has shown that allergic mice have poor vascular responses and systemic inflammation, with adenosine aerosol exacerbating these effects by activating $A_{1}$ adenosine receptors.

The four adenosine receptor subtypes, i.e., the $A_{1}, A_{2 A}, A_{2 B}$ and $A_{3}$, have different modulatory roles in asthma, and the cardiovascular system (Belardinelli et al., 1989; Mubagwa et al., 1996; Shryock and Belardinelli, 1997). Many reports suggest that the $A_{1}$ adenosine receptor is involved in direct bronchoconstrictor effects of adenosine. $A_{1}$ 
receptor expression was found to be elevated in a rabbit model of asthma and the use of an $A_{1}$ antisense nucleotide to inhibit this upregulation resulted in blunted bronchoconstriction to adenosine (Nyce and Metzger, 1997; Abebe and Mustafa, 1998). Use of a selective $A_{1}$ antagonist produced significant reduction of airway hyperresponsiveness in allergic rabbits by blocking these receptors (Obiefuna et al., 2005). A very recent study reported that the expression of $A_{1}$ receptor is significantly elevated in airway smooth muscle in asthmatic patient (Brown et al., 2008). Other than the effects on airway smooth muscle, the $A_{1}$ receptor has been implicated in increased mucin production in human tracheal cells (McNamara et al., 2004) and in mediating monocyte phagocytosis (Salmon et al., 1993). All these studies suggest a strong role for the $\mathrm{A}_{1}$ receptor in asthma, both in airway obstruction and inflammation

$A_{1}$ receptors also have systemic effects and are involved in blood pressure regulation (Brown et al., 2006) and vasoconstriction (Shepherd et al., 1996; Talukder et al., 2002b; Hansen et al., 2003; Tawfik et al., 2005). However, the role of the $A_{1} A R$ in the control of vascular tone and systemic inflammation in an allergic model of asthma has not been characterized. In addition, the vascular effects of $A_{1}$ receptors in response to exogenous adenosine challenge as an added insult in a murine model of asthma have not been studied previously. Therefore, this study was undertaken to investigate the effects of allergen challenge and inhaled adenosine on vascular reactivity and systemic inflammation using our murine model of asthma in $\mathrm{A}_{1} \mathrm{WT}$ and $\mathrm{KO}$ mice. We also determined the role of the $\mathrm{A}_{1} \mathrm{AR}$ in airway responsiveness by whole body plethysmography. Our data suggest that asthmatic $\mathrm{A}_{1} \mathrm{WT}$ mice have altered peripheral vascular reactivity, systemic inflammation and increased bronchoconstriction with 
inhaled adenosine further exacerbating these effects, compared to $\mathrm{A}_{1} \mathrm{KO}$ mice, in which these responses were not elicited.

\section{Materials and Methods}

Animals: Balb/c mice $\left(\mathrm{A}_{1} \mathrm{WT}\right)$ 8-10 weeks old males were obtained from Harlan Sprague Dawley (Indianapolis, IN) and $\mathrm{A}_{1} \mathrm{KO}$ mice were obtained from Stephen Tilley, Pulmonary and Critical Care, School of Medicine, University of North Carolina, Chapel Hill. The animals were maintained on a ragweed-free diet. All experimental animals used in this study were under a protocol approved by the Institutional Animal Care and Use Committee of West Virginia University.

Animal sensitization: Sensitization was performed according to the protocol described earlier from this laboratory (Fan and Mustafa, 2002; Fan et al., 2003; Oldenburg and Mustafa, 2005; Fan and Mustafa, 2006; Mustafa et al., 2007). This model of allergic asthma has been shown to develop airway inflammation and airway hyper-reactivity to methacholine. The study comprised of six groups of animals: a) $\mathrm{A}_{1} \mathrm{WT}$ Control ( $\underline{\mathrm{A}}_{1} \underline{\mathrm{WT}}$ $\underline{\mathrm{CON}})$; b) $\mathrm{A}_{1} \mathrm{WT}$ Allergen sensitized and challenged ( $\left.\underline{\mathrm{A}}_{1} \underline{\mathrm{WT}} \mathrm{SEN}\right)$; c) $\mathrm{A}_{1} \mathrm{WT}$ Allergen sensitized and challenged further with $6 \mathrm{mg} / \mathrm{ml}$ of adenosine aerosol for $2 \mathrm{~min}$ on day 14 $\left(\underline{\mathrm{A}}_{1} \underline{\mathrm{WT}} \mathrm{SEN}+\mathrm{AD}\right) ;$ d) $\mathrm{A}_{1} \mathrm{KO}$ Control $\left(\underline{\mathrm{A}_{1}} \underline{\mathrm{KO} \mathrm{CON}}\right)$; e) $\mathrm{A}_{1} \mathrm{KO}$ Allergen sensitized and challenged ( $\left.\left.\underline{\mathrm{A}}_{1} \underline{\mathrm{KO} S E N}\right) ; \mathrm{f}\right) \mathrm{A}_{1} \mathrm{KO}$ Allergen sensitized and challenged further challenged with $6 \mathrm{mg} / \mathrm{ml}$ of adenosine aerosol for $2 \mathrm{~min}$ on day 14 ( $\left.\underline{\mathrm{A}}_{1} \underline{\mathrm{KO}} \mathrm{SEN}+\mathrm{AD}\right)$. Experiments carried out previously with $\mathrm{A}_{1} \mathrm{WT} \mathrm{CON}$ mice subject to adenosine challenge $\left(\mathrm{A}_{1} \mathrm{WT}\right.$ $\mathrm{CON}+\mathrm{AD}$ ) showed that this group was not different from $\mathrm{A}_{1} \mathrm{WT} \mathrm{CON}$ and, hence, this 
group was not included for further experimentation. Mice were sensitized on days 1 and 6 with i.p. injections of ragweed allergen (Greer Laboratories, Lenoir, NC), $200 \mu \mathrm{g}$ per dose with $200 \mu \mathrm{L}$ Imject Alum (Pierce Laboratories, Rockford, IL). Non-sensitized control animals received only the Imject alum with the same volumes. 10 days after sensitization, the mice were placed in a Plexiglas chamber and challenged with $1 \%$ aerosolized ragweed or with $0.9 \%$ saline as a control, using an ultrasonic nebulizer (DeVilbiss Somerset, PA) for 20 minutes both in the morning and afternoon for three consecutive days. The aerosolization of allergen was performed at a flow rate of 2 $\mathrm{mL} / \mathrm{min}$, and the aerosol particles had a median aerodynamic diameter of less $4 \mu \mathrm{m}$ (De Vilbiss).

Acute elevations in lung adenosine levels were produced experimentally by adenosine inhalation (6 $\mathrm{mg} / \mathrm{ml}$ for $2 \mathrm{~min}$ on day 14 ) to $\mathrm{SEN}+\mathrm{AD}$ group to further enhance allergen-induced effects. This dose was chosen based on our previous studies in this model (Fan and Mustafa, 2002; Fan and Jamal Mustafa, 2006). Adenosine inhalation in this model has been shown to enhance allergen-induced airway inflammation and airway hyper-reactivity to adenosine (or its analog NECA) (Fan and Mustafa, 2002; Fan et al., 2003; Fan and Mustafa, 2006). ADA-deficient mice having sustained and chronic elevations in lung adenosine levels have also been shown to have similar features (Chunn et al., 2001). We chose $24 \mathrm{hr}$ post-adenosine inhalation for our current studies based on an earlier study from our lab which showed maximum eosinophilic inflammation in airways after $24 \mathrm{hr}$ of adenosine inhalation (Fan and Mustafa, 2006), which is a hallmark of asthmatic inflammation. CON and SEN groups received only saline on day 14 . 
Twenty-four hours after the last challenge, animals were sacrificed for collection of aorta and blood for further experiments.

\section{Preparation of isolated mouse aorta and isometric force measurement}

Mice were sacrificed by anesthesia with pentabarbitol sodium $(65 \mathrm{mg} / \mathrm{kg}$, i.p.) followed by thoracotomy and removal of aorta that was then cut transversely into $3-4 \mathrm{~mm}$ rings. The rings were mounted vertically between two stainless steel wire hooks and then suspended in $10 \mathrm{~mL}$ organ baths containing Krebs-Henseleit buffer. The Krebs-Henseleit buffer (pH 7.4) containing $118 \mathrm{mM} \mathrm{NaCl}, 4.8 \mathrm{mM} \mathrm{KCl}, 1.2 \mathrm{mM} \mathrm{MgSO} 4,1.2 \mathrm{mM}$ $\mathrm{KH}_{2} \mathrm{PO}_{4}, 25 \mathrm{mM} \mathrm{NaHCO}, 11 \mathrm{mM}$ glucose and $2.5 \mathrm{mM} \mathrm{CaCl}_{2}$ was maintained at $37^{\circ} \mathrm{C}$ with continuous bubbling of $95 \% \mathrm{O}_{2}$ and $5 \% \mathrm{CO}_{2}$. For measurement of isometric force response, aortic rings were equilibrated for 90 min with a resting force of $1 \mathrm{~g}$ that has been used earlier in our laboratory (Tawfik et al., 2005; Ansari et al., 2007b) and change of the bathing solution at $15 \mathrm{~min}$ interval. At the end of equilibration period, tissues were contracted with $50 \mathrm{mM} \mathrm{KCl}$ to check the contractility of individual aortic rings twice which were washed out with Krebs-Henseleit buffer. Aortic rings were then constricted with phenylephrine $\left(\mathrm{PE}, 10^{-7} \mathrm{M}\right)$ to obtain a steady contraction and changes in tension were monitored continuously with fixed range precision force transducer (TSD, $125 \mathrm{C}$, BIOPAC system) connected to the differential amplifier (DA 100B, BIOPAC system). The data were recorded using MP100, BIOPAC digital acquisition system and analyzed using Acknowledge 3.5.7 software (BIOPAC system). 


\section{Contraction/relaxation experiments}

After equilibration, the responsiveness and stability of individual rings were checked by successive administration of submaximally effective concentration of PE $\left(10^{-7} \mathrm{M}\right)$. The integrity of the vascular endothelium was assessed pharmacologically by acetylcholine $\left(10^{-7} \mathrm{M}\right)$ to produce relaxation of PE pre-contracted rings. Aortic rings were then washed several times with Krebs-Henseleit solution, and allowed to equilibrate for 30 min before the experimental protocol began.

\section{Experimental protocol}

The concentration-response curves (CRCs) for NECA $\left(10^{-9}-10^{-5} \mathrm{M}\right)$ were run parallel in aortic rings from all the groups. In all cases, NECA was added to yield the next higher concentration only when the response to the earlier dose reached a steady state. Contraction/relaxation responses were expressed as a percentage increase/decrease in the contraction with respect to $\mathrm{PE}$ (alone) in response to each concentration of agonist used.

\section{Assessment of systemic inflammation}

Mice were euthanized by pentobarbitone sodium ( $65 \mathrm{mg} / \mathrm{mL}$, i.p.), followed by collection of blood by cardiac puncture in heparinized syringes. The blood collected from different groups was centrifuged at $800 \mathrm{~g}$ for $10 \mathrm{~min}$ at $4^{\circ} \mathrm{C}$ and the resulting plasma was used for cytokine assays.

Multiplex cytokine assay: Cytokine assay of IL-5, TNF $\alpha$ and IL-13 in the plasma was measured by a commercial kit from Linco Research (St. Charles, Missouri) using the Luminex 200 system (Luminex Corp., Austin, Tx), which is a multianalyte bioassay 
detection system capable of performing up to 100 assays simultaneously in a single microtiter plate well. This system uses polystyrene microspheres internally dyed with red and infrared fluorophores that can be individually identified. The fluorescent microspheres were coated with capturing antibodies specific for different chemokines. The chemokine-captured beads after incubation with the sample were then mixed with phycoerythrin-conjugated detection antibodies to form immune complexes. Following incubation, washing and acquisition of fluorescence data, the concentration results were generated in graphical format using the standard curve generated for each cytokine. Results were expressed in $\mathrm{pg} / \mathrm{mL}$.

\section{Airway responsiveness to Methacholine (MCh) and NECA}

The airway responsiveness was assessed by whole body plethysmography using the chambers obtained from Buxco Inc. (Max II; Buxco Systems, Wilmington, NC). This system enables the measurement of airway obstruction using a dimensionless parameter called enhanced pause or Penh. Higher the Penh values, greater is the airway obstruction. Penh has been shown to correlate with airway resistance and dynamic compliance (Justice et al., 2001). Unrestrained mice were placed in individual Plexiglas chambers twenty four hours after the last allergen challenge and subjected to increasing concentrations of $\mathrm{MCh}(1.5-48.0 \mathrm{mg} / \mathrm{ml})$ to obtain concentration-responses. In case of SEN+AD groups, this was 24 hours post adenosine aerosolization. Concentrationresponses to NECA were performed 24 hours post the MCh experiment. After obtaining baseline and vehicle Penh values, mice were exposed to increasing concentrations of NECA (23.44-750 $\mu \mathrm{g} / \mathrm{ml})$ via the Buxco aerosol delivery system (version 1.5; Buxco, 
Wilmington, NC). Each concentration of NECA was aerosolized for 2 minutes and the Penh readings were recorded for 5 minutes to establish a dose-response relationship. The next dose was not administered until the mice had returned to baseline Penh levels. Airway responsiveness was normalized to the vehicle control (normal saline) and expressed as a percentage increase in Penh.

\section{Drugs used}

Acetylcholine, adenosine and phenylephrine were dissolved in distilled water. 5'-Nethylcarboxamidoadenosine (NECA) was dissolved in $100 \%$ DMSO as a $10 \mathrm{mM}$ stock solution for vascular reactivity experiments. The final concentration of DMSO in organ bath (bath volume: $10 \mathrm{~mL}$ ) had no effect by itself on the aortic rings (Ansari et al., 2007b). For Penh responses, MCh was dissolved in $0.9 \%$ saline and NECA was dissolved in $100 \%$ ethanol to create a stock solution from which subsequent dilutions were made with $0.9 \%$ saline. Unless stated otherwise, all chemicals were of the highest grade available and were purchased from Sigma Chemicals (St. Louis, MO).

\section{Statistical Analysis}

The data were expressed as mean \pm SEM. Comparisons among different groups were analyzed by ANOVA (analysis of variance) followed by Tukey's multiple comparison test/ Bonferroni's selected pair test. Comparison between two groups was assessed by unpaired t-test. A p value of less than 0.05 was considered as the level of significance. All statistical analyses were performed using the GraphPad Prism statistical package. 


\section{Results}

\section{Systemic inflammation in control, allergic and adenosine aerosolized allergic mice}

Table 5.1 shows the multiplex cytokine profile in all the groups. Allergen challenge significantly increased plasma levels of inflammatory cytokines IL-5 and IL-13 in $\mathrm{A}_{1} \mathrm{WT}$ SEN as compared to $\mathrm{A}_{1} \mathrm{WT}$ Con and all groups of $\mathrm{A}_{1} \mathrm{KO}$ mice. Allergen sensitized and challenged $\mathrm{A}_{1} \mathrm{WT}$ mice exposed to adenosine aerosol ( $\mathrm{SEN}+\mathrm{AD}$ ) had the highest level of the pro-inflammatory cytokines compared to other groups. Other cytokines in the panel were either undetectable or not different among the groups (data not shown). These data suggest activation of the $\mathrm{A}_{1}$ receptor has pro-inflammatory effects.

\section{Vascular reactivity in control, allergic and allergic + adenosine groups}

The aortic relaxation/contraction responses to NECA were studied in all 6 groups. Organ bath data showed a concentration dependent relaxation response to NECA in $\mathrm{A}_{1} \mathrm{WT}$ CON, while aortic relaxations were impaired in $\mathrm{A}_{1} \mathrm{WT}$ SEN aorta with a maximum relaxation of 7\% (Fig 5.1 A). NECA failed to elicit any relaxation response in SEN+AD; it produced a concentration dependent contractile response, with a maximum contraction of $35 \%$ at $10^{-6} \mathrm{M}$ (Fig $\left.5.1 \mathrm{~A}\right)$. In contrast, all 3 groups of $\mathrm{KO}$ mice showed concentrationdependent relaxation and there was no difference in the responses between the groups (Fig $5.1 \mathrm{~B}$ ). These data show that allergen sensitization and challenge altered the vascular reactivity with adenosine aerosol further exacerbating it in allergic $\mathrm{A}_{1}$ WTmice, indicating that the $A_{1}$ receptor was responsible for the low adenosine-mediated vascular relaxation observed. Comparison between respective groups of SEN and SEN+AD WT and KO groups are shown in figures 5.2 and 5.3. 


\section{Endothelial function in control, allergic and allergic + adenosine groups}

Figure 5.4 shows the endothelial response to ACh in all experimental groups. $\mathrm{A}_{1}$ WT SEN $(\sim 39 \%)$ and $\mathrm{SEN}+\mathrm{AD}(\sim 38 \%)$ groups had significantly lower $(\mathrm{P}<0.01)$ endothelial response to acetylcholine compared to WT controls ( $\sim 65 \%$ relaxation). There was no difference in endothelial response between any group of $\mathrm{A}_{1} \mathrm{KO}$ mice and between the $\mathrm{KO}$ groups and $\mathrm{A}_{1} \mathrm{WT} C \mathrm{CON}$; however $\mathrm{A}_{1} \mathrm{KO}$ SEN and $\mathrm{A}_{1} \mathrm{KO}$ SEN+ AD had significantly higher endothelial relaxation than $\mathrm{A}_{1} \mathrm{WT}$ SEN and $\mathrm{A}_{1}$ WT SEN+ AD groups $(\mathrm{P}<0.05)$ These data show that allergen challenge probably led to endothelial dysfunctional in allergic $\mathrm{A}_{1} \mathrm{WT}$ mice.

\section{Airway responsiveness to Methacholine (MCh) and NECA}

The airway responsiveness to MCh (Fig 5.5) was assessed and there was no difference between control $\mathrm{A}_{1} \mathrm{WT}$ and $\mathrm{KO}$ mice. All groups of sensitized mice WT and KO had significantly increased airway response to MCh compared to respective controls but there was no difference between sensitized $\mathrm{A}_{1} \mathrm{WT}$ and KO mice. Next, the response to NECA was assessed (Fig 5.6). Although baseline Penh values for control $\mathrm{A}_{1} \mathrm{WT}(284.05 \pm 65.4)$ were higher than $\mathrm{A}_{1} \mathrm{KO}(180.36 \pm 22.52)$, the difference was not statistically significant. However, allergic $\mathrm{A}_{1}$ WT SEN and $\mathrm{A}_{1}$ WT SEN+AD mice had significantly higher airway responsiveness, with the response being highest in the $\mathrm{A}_{1} \mathrm{WT}$ SEN+AD group. In contrast, $\mathrm{A}_{1} \mathrm{KO}$ SEN and SEN+AD groups had comparable response to $\mathrm{A}_{1} \mathrm{KO} \mathrm{CON}$ group. These data indicate that adenosine mediated hyper-responsiveness is mediated through the $\mathrm{A}_{1}$ receptor. 
Table 5.1: Systemic inflammation as assessed by levels of inflammatory cytokines in plasma of $\mathrm{A}_{1} \mathrm{WT}$ and $\mathrm{A}_{1} \mathrm{KO}$ control $(\mathrm{CON})$, allergic (SEN) and adenosine aerosolized allergic $(\mathrm{SEN}+\mathrm{AD})$ mice; Values are expressed as Mean $\pm \mathrm{SEM}(\mathrm{n}=4-8) . * \mathrm{P}<0.05$ compared to $\mathrm{A}_{1} \mathrm{WT} \mathrm{CON}$; $\# \mathrm{P}<0.05$ compared to $\mathrm{A}_{1} \mathrm{WT}$ SEN.

\begin{tabular}{|c|c|c|c|c|c|c|}
\hline \multirow{2}{*}{ INFLAMMATORY } & \multicolumn{2}{|c|}{ CON } & \multicolumn{2}{c}{ SEN } & \multicolumn{2}{c|}{ SEN+AD } \\
\cline { 2 - 6 } & $\mathrm{A}_{1} \mathrm{WT}$ & $\mathrm{A}_{1} \mathrm{KO}$ & $\mathrm{A}_{1} \mathrm{WT}$ & $\mathrm{A}_{1} \mathrm{KO}$ & $\mathrm{A}_{1} \mathrm{WT}$ & $\mathrm{A}_{1} \mathrm{KO}$ \\
\hline $\mathrm{IL}-5$ & $3.35 \pm 0.14$ & $3.98 \pm 0.93$ & $8.22 \pm 1.65^{*}$ & $4.078 \pm 0.57$ & $11.12 \pm 1.5^{*}$ & $3.88 \pm 1.50$ \\
\hline IL13 & $27.44 \pm 5.57$ & UNDETECTED & $45.41 \pm 9.91^{*}$ & UNDETECTED & $170 \pm 49.97^{*} \#$ & UNDETECTED \\
\hline TNF- $\alpha$ & $6.66 \pm 1.03$ & UNDETECTED & $6.25 \pm 0.23$ & UNDETECTED & $14.22 \pm 3.60^{*} \#$ & UNDETECTED \\
\hline
\end{tabular}


Figure 5.1 Concentration-response curves for NECA-mediated relaxation/contraction in $\mathrm{A}_{1} \mathrm{WT}(\mathrm{A})$ and $\mathrm{A}_{1} \mathrm{KO}(\mathrm{B})$ with control $(\mathrm{CON})$, allergic $(\mathrm{SEN})$ and adenosine aerosolized allergic $(\mathrm{SEN}+\mathrm{AD})$ groups. Values are expressed as mean $\pm \operatorname{SEM}(n=4)$. On the ordinate, positive and negative values indicate relaxation and contraction, respectively. ${ }^{*} \mathrm{P}<0.05$ as compared to $\mathrm{CON} ; \$ \mathrm{P}<0.05$ as compared to $\mathrm{SEN}$.

(A)

$A_{1}$ WT

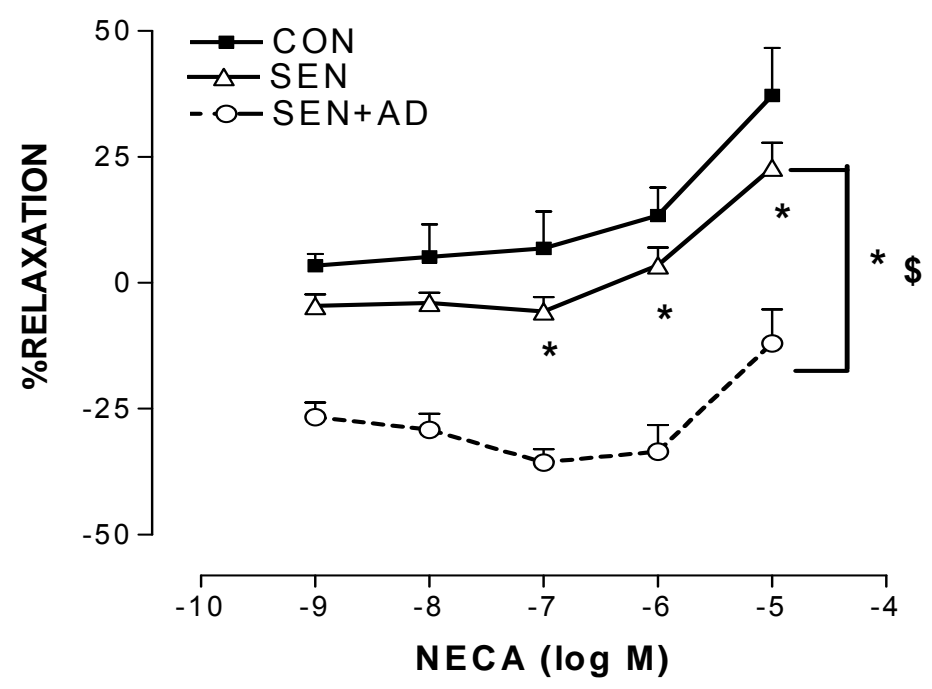

(B)
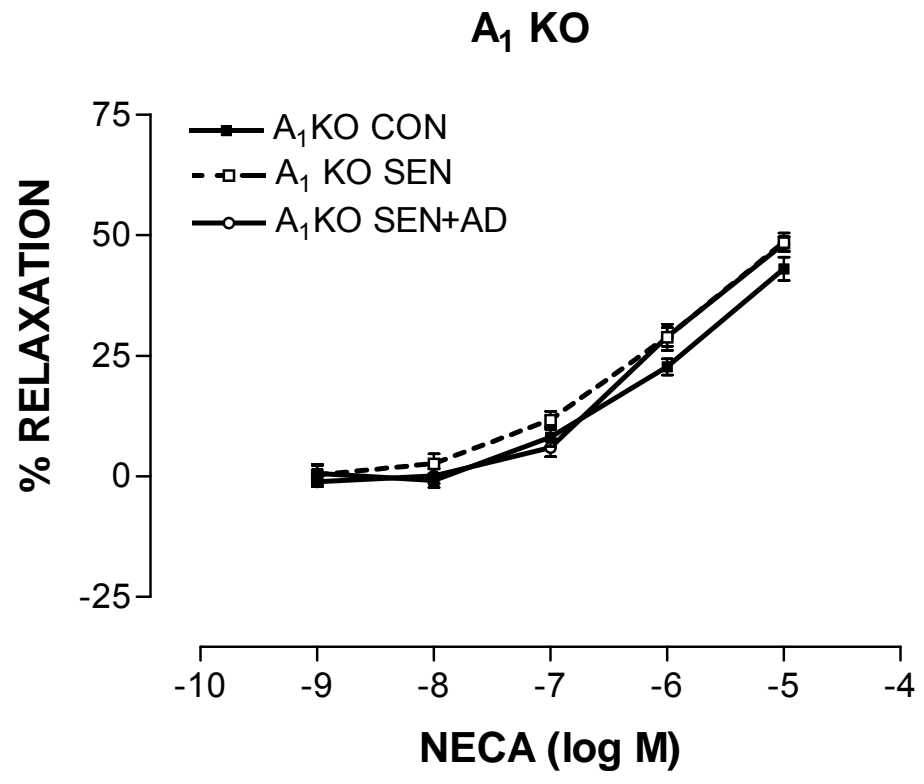
Figure 5.2 Comparison between $\mathrm{A}_{1} \mathrm{KO}$ and $\mathrm{A}_{1} \mathrm{WT}$ sensitized mice. Values are expressed as mean $\pm \operatorname{SEM}(n=4)$. On the ordinate, positive and negative values indicate relaxation and contraction, respectively. ${ }^{*} \mathrm{P}<0.05$

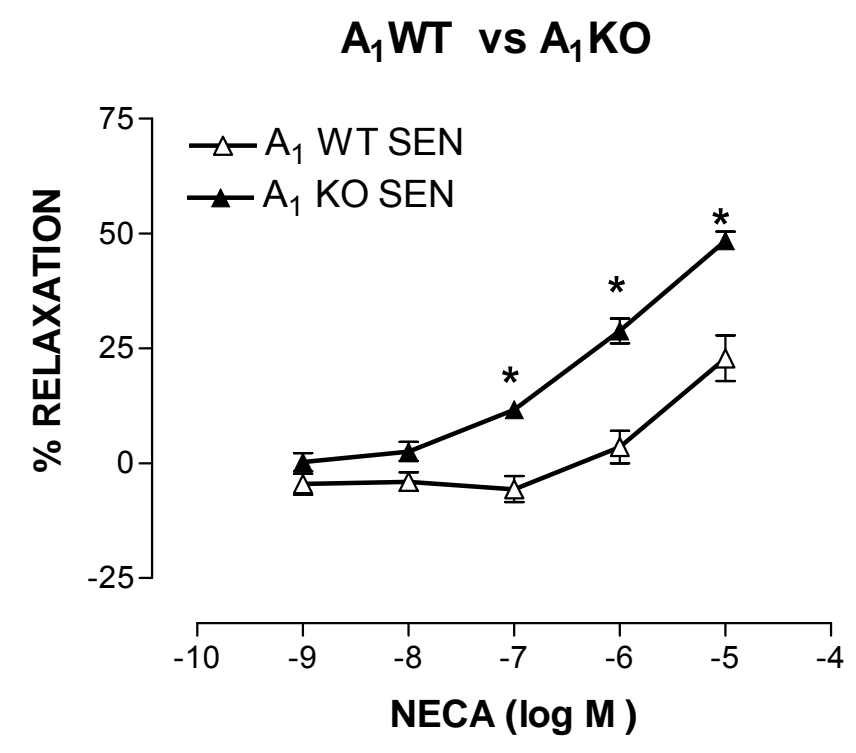


Figure 5.3 Comparison between $\mathrm{A}_{1} \mathrm{KO}$ and $\mathrm{A}_{1} \mathrm{WT} \mathrm{SEN}+\mathrm{AD}$ mice. Values are expressed as mean $\pm \operatorname{SEM}(n=4)$. On the ordinate, positive and negative values indicate relaxation and contraction, respectively. ${ }^{*} \mathrm{P}<0.05$

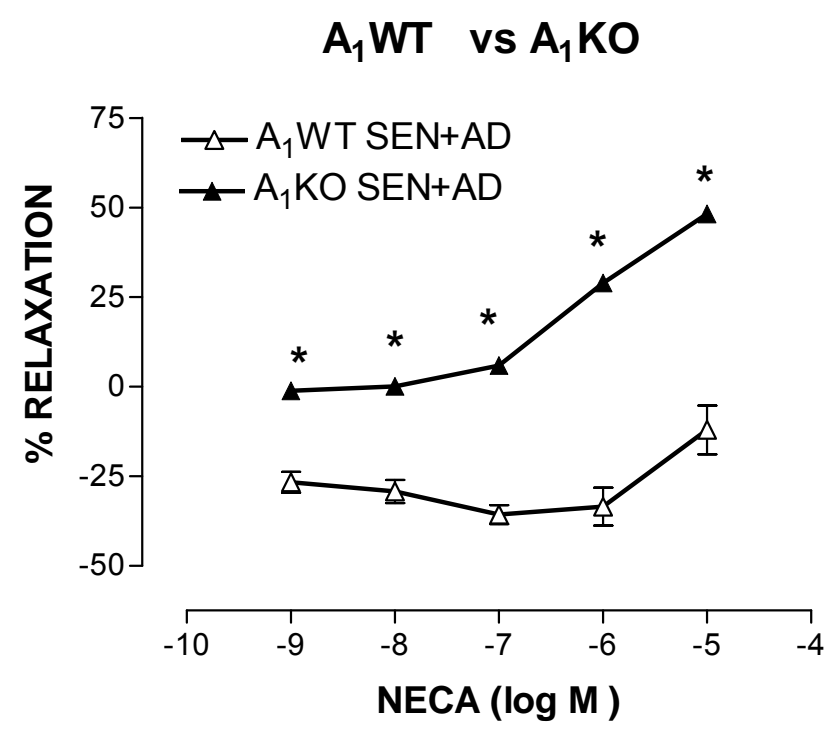


Fig 5.4 Endothelial response to $\mathrm{ACh}$ in $\mathrm{CON}, \mathrm{SEN}$ and $\mathrm{SEN}+\mathrm{AD} \mathrm{A}_{1} \mathrm{WT}$ and $\mathrm{A}_{1} \mathrm{KO}$ mice. $\mathrm{A}_{1} \mathrm{WT}$ SEN and $\mathrm{SEN}+\mathrm{AD}$ groups were significantly different from $\mathrm{A}_{1} \mathrm{WT} C \mathrm{CON}$ $* \mathrm{P}<0.01$ and $\mathrm{A}_{1} \mathrm{KO} \mathrm{SEN}, \mathrm{SEN}+\mathrm{AD} \# \mathrm{P}<0.05$

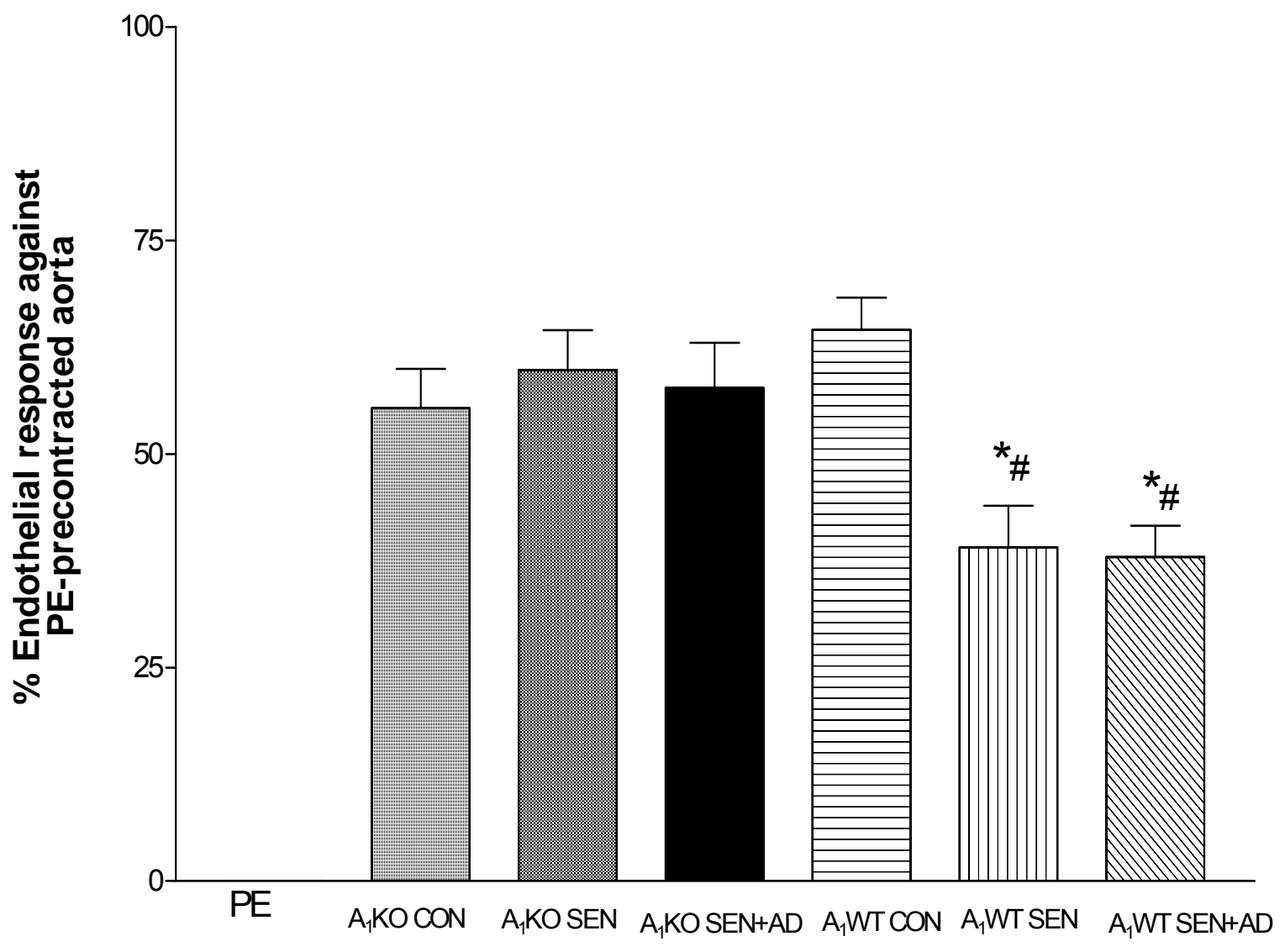


Figure 5.5 Airway responsiveness to $\mathrm{MCh}$ in $\mathrm{A}_{1} \mathrm{KO}$ and $\mathrm{A}_{1} \mathrm{WT}$ mice. Values are expressed as mean \pm SEM ( $n=4-8)$. On the ordinate, airway response is expressed as $\%$ of the vehicle. ${ }^{*} \mathrm{P}<0.05 \mathrm{~A}_{1} \mathrm{WT} \mathrm{SEN}$ and $\mathrm{SEN}+\mathrm{AD}$ compared to $\mathrm{A}_{1} \mathrm{WT} \mathrm{CON}$; \# $\mathrm{P}<0.05$ $\mathrm{A}_{1} \mathrm{KO} \mathrm{SEN}$ and $\mathrm{SEN}+\mathrm{AD}$ compared to $\mathrm{A}_{1} \mathrm{KO} \mathrm{CON}$

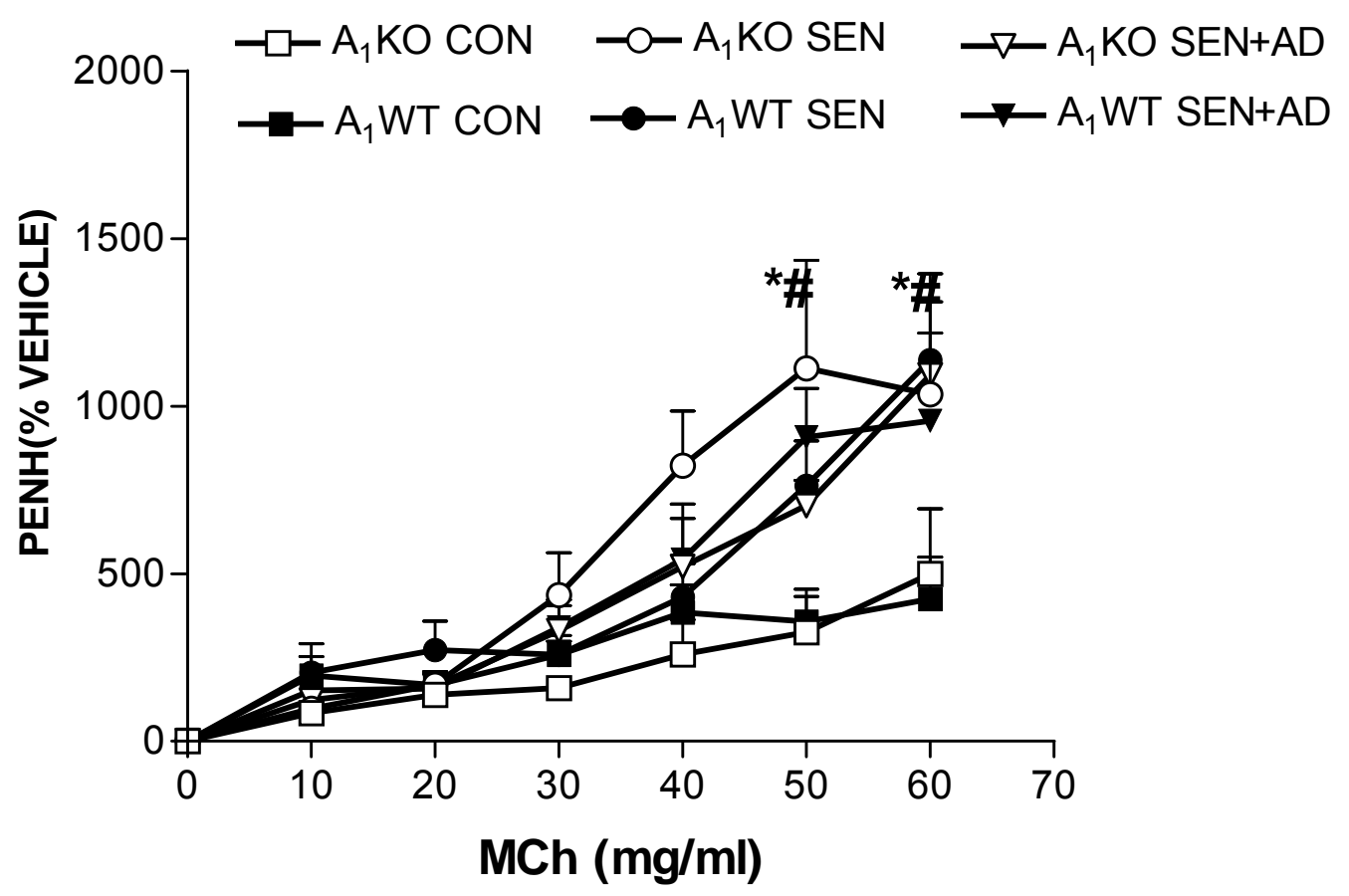


Figure 5.6 Airway responsiveness to NECA in $\mathrm{A}_{1} \mathrm{KO}$ and $\mathrm{A}_{1} \mathrm{WT}$ mice. Values are expressed as mean \pm SEM $(n=4-8)$. On the ordinate, airway response is expressed as $\%$ of the vehicle. ${ }^{*} \mathrm{P}<0.01$ compared to $\mathrm{A}_{1} \mathrm{KO} \mathrm{CON} ; \$ \mathrm{P}<0.01$ compared to $\mathrm{A}_{1} \mathrm{KO} \mathrm{SEN} ; \# \mathrm{P}<$ 0.05 compared to $\mathrm{A}_{1} \mathrm{KO} \mathrm{SEN}+\mathrm{AD} ; \% \mathrm{P}<0.05$ compared to $\mathrm{A}_{1} \mathrm{WT} \mathrm{SEN}, @ \mathrm{P}<0.05$ compared to $\mathrm{A}_{1} \mathrm{WT} \mathrm{CON}$.

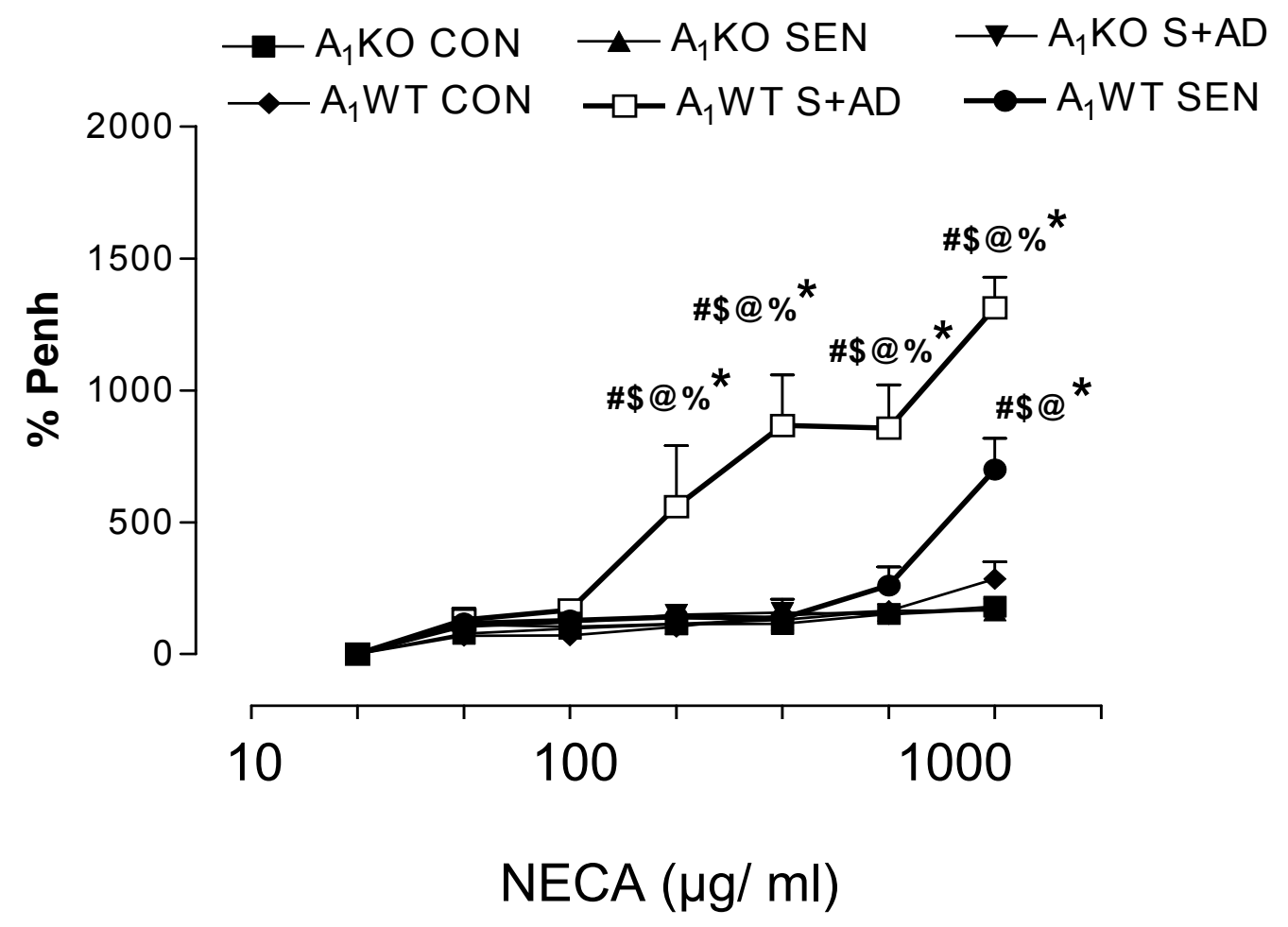




\section{Discussion}

The principal finding of the present study is that allergic $\mathrm{A}_{1} \mathrm{WT}$ mice had systemic inflammation, increased airway responsiveness and impaired vasorelaxation to NECA, a non-selective adenosine analog. These outcomes were further aggravated after acute adenosine aerosol challenge in these mice. Responses in allergic $\mathrm{A}_{1} \mathrm{KO}$ mice were not different from non-allergic wild type controls, indicating that the $A_{1}$ adenosine receptor was responsible for alterations in vascular reactivity, airway hyperresponsiveness and increased inflammation. Administration of NECA caused increased airway responsiveness in allergic $\mathrm{A}_{1} \mathrm{WT}$ mice which was absent in corresponding $\mathrm{A}_{1} \mathrm{KO}$ mice. Endothelium was found to be dysfunctional in allergic $\mathrm{A}_{1} \mathrm{WT}$ mice compared to non-allergic $\mathrm{A}_{1} \mathrm{WT}$ controls, while both allergic and non-allergic $\mathrm{A}_{1} \mathrm{KO}$ mice had no difference in endothelial responses.

Adenosine is chronically elevated in asthmatic lungs (Mann et al., 1986b; Mann et al., 1986a; Driver et al., 1993). Evidence indicates adenosine may be involved in the release of inflammatory mediators in the lung and systemic circulation by acting on its receptors present on different cells including mast cells, eosinophils, neutrophils and other inflammatory cells (Driver et al., 1991; Fan and Jamal Mustafa, 2006; Nadeem and Mustafa, 2006; Spicuzza et al., 2006) and can thus contribute to the severity of lung inflammation. Adenosine is a known bronchoprovocant (Cushley et al., 1983) and experimentally induced temporary elevations in lung adenosine levels through inhalation of adenosine (resulting from breakdown of adenosine 5'-monophosphate) cause an increase in infiltration of eosinophils in patients with asthma (van den Berge et al., 2004). A recent study from our lab has also shown increased release of inflammatory cell 
markers in the lung and plasma after inhalation of adenosine aerosol in allergic mice (Fan and Mustafa, 2002). However, the systemic effects of such an inhalation with respect to involvement of specific adenosine receptors have not been studied previously. Adenosine aerosol in human asthmatics causes increased release of neutrophil chemotactic factor in serum (Driver et al., 1991). These studies suggest that adenosine enhances the release of systemic inflammatory mediators from inflammatory cells

Systemic inflammation has been reported previously in human asthmatics and animal models of asthma (Jousilahti et al., 2002; Hazarika et al., 2004). Neutrophils and eosinophils are increased in bronchoalveolar lavage and blood in a murine model of asthma (Hazarika et al., 2007). Systemic inflammatory markers have also been shown to be elevated in patients with asthma and in allergic mouse model of asthma after adenosine aerosol challenge. (Driver et al., 1991; Fan and Jamal Mustafa, 2006). Based on the findings of these studies, we investigated the cytokine profile in systemic circulation in allergic $\mathrm{A}_{1} \mathrm{WT}$ and $\mathrm{A}_{1} \mathrm{KO}$ mice. We found that while allergic $\mathrm{A}_{1} \mathrm{WT}$ mice had significantly elevated levels of pro-inflammatory cytokines, allergic $\mathrm{A}_{1} \mathrm{WT}$ mice exposed to acute adenosine aerosol had further exacerbation of systemic inflammation as evidenced by the finding that several pro-inflammatory cytokines levels (IL-13, MCP-1, and TNF- $\alpha$ ) were increased most in this group. In $\mathrm{A}_{1} \mathrm{KO}$ mice, both allergic and control groups either had undetected or non-significant levels of inflammatory markers, suggesting the absence of the $A_{1}$ receptor was related to lower inflammation. From the mediator profile, IL-13 was significantly higher in the plasma of $\mathrm{A}_{1} \mathrm{WT}$ SEN mice, with adenosine challenge exacerbating it even further. IL-13 is an important mediator in asthma and has been implicated in lung inflammation, airway remodeling and airway 
hyperreactivity (Grunig et al., 1998; Lowry et al., 2008). Adenosine and IL-13 interact positively, with each increasing the levels of the other in studies done with asthmatic mice (Blackburn et al., 2003). IL-13 and adenosine thus are important in lung inflammation but their role in systemic inflammation is not known. Our data suggest a pro-inflammatory role for IL-13 and adenosine mediated systemic inflammation via the $\mathrm{A}_{1}$ receptors.

Asthma has been associated with an increased incidence of negative cardiovascular outcomes (Drislane et al., 1987; Toren and Lindholm, 1996; Iribarren et al., 2004; Knoflach et al., 2005). While asthmatic inflammation is believed to responsible for the development of these cardiovascular effects, there is little information linking the two, especially in relation to the vascular effects of specific adenosine receptors. In the present study, NECA, a non-selective adenosine analog produced a concentrationdependent vasorelaxation in control $\mathrm{A}_{1} \mathrm{WT}$ mice, which was impaired in allergic $\mathrm{A}_{1} \mathrm{WT}$ mice. Vascular reactivity to NECA was further altered in aorta of allergic $A_{1}$ WT mice that had received aerosolized adenosine. In contrast, NECA produced a concentrationdependent vasorelaxation response in allergic and non-allergic $\mathrm{A}_{1} \mathrm{KO}$ groups. These findings strongly suggest that the $A_{1}$ receptor indeed is responsible for poor vascular responses in allergic mice.

In a recent study from this laboratory, we found that allergic mice had lower endothelial relaxation suggesting that allergen exposure and development of allergic asthma somehow resulted in endothelial dysfunction (Ponnoth et al., 2008). In the present study, we observed that there was no difference in the endothelial response between control and allergic $\mathrm{A}_{1} \mathrm{KO}$ mice as opposed to significantly lower endothelial relaxation 
in allergic $\mathrm{A}_{1} \mathrm{WT}$ mice compared to $\mathrm{A}_{1} \mathrm{WT}$ controls. The exact cause for this dysfunction is not clear but it could possibly be due to the $A_{1}$ receptor-mediated increase in systemic inflammatory cytokines. These inflammatory cytokines are known to suppress eNOS and nitric oxide production (Cardaropoli et al., 2003; Li et al., 2004). For the first time, the $\mathrm{A}_{1}$ receptor specifically has been shown to affect the endothelium functionality in allergic mice. Further studies are required to delineate the exact mechanism for the role of the $A_{1} A R$ in alteration of endothelial function especially the signaling pathways that may be involved.

Whole body plethysmography has been used previously to determine the extent of airway responsiveness and as an index of airway obstruction (Drazen et al., 1999; Fan and Mustafa, 2002; Fan et al., 2003; Oldenburg and Mustafa, 2005). We used this method to determine the differences between $\mathrm{A}_{1} \mathrm{WT}$ and $\mathrm{KO}$ responses to MCh and NECA. MCh produced higher airway responsiveness in both $\mathrm{A}_{1} \mathrm{WT}$ and $\mathrm{KO}$ sensitized animals compared to controls. No difference was observed between $\mathrm{A}_{1} \mathrm{WT}$ and $\mathrm{KO}$ mice. However, the response to the non-selective adenosine analog NECA was different between $\mathrm{A}_{1} \mathrm{KO}$ and $\mathrm{WT}$ mice. There was no difference in NECA-mediated airway response in all three groups of $A_{1} \mathrm{KO}$ mice, while $\mathrm{A}_{1} \mathrm{WT}$ SEN mice had significantly higher responses. The highest response was observed in $\mathrm{A}_{1}$ WT SEN+AD, which was significantly different from all other study groups. The $A_{1}$ receptor has been implicated in the direct adenosine-mediated bronchoconstrictor response (Nyce and Metzger, 1997; Abebe and Mustafa, 1998) and a selective $A_{1}$ antagonist produced significant reduction of airway hyper-responsiveness in allergic rabbits by blocking these receptors (Obiefuna 
et al., 2005). Our data supports a role for $A_{1}$ receptor-mediated airway hyperresponsiveness and also shows that adenosine challenge exacerbates the response.

In conclusion, our findings provide evidence for the first time that the $\mathrm{A}_{1}$ adenosine receptor mediates alterations in systemic parameters (inflammation, lower endothelial response and impaired vasorelaxation) and airway hyper-responsiveness as a result of allergen exposure and adenosine aerosol challenge in sensitized mice. Understanding the exact contribution of adenosine and adenosine $\mathrm{A}_{1}$ receptor mediatedsystemic effects with respect to mechanisms and signal transduction would provide an important tool in the prevention of systemic inflammation and harmful systemic side effects in designing therapies for asthma. Ultimately, this could be beneficial in lowering cardiovascular events in asthmatics. 


\section{CHAPTER SIX}

\section{CONCLUSION}

The work presented in this dissertation establishes that asthma has detrimental effects beyond lungs and airways in allergic mice. Systemic inflammation, endothelial dysfunction and altered vascular reactivity appear to be associated with asthma. Adenosine plays an important role in these effects and exogenously administered adenosine to increase the lung levels experimentally beyond the allergen exposure exacerbates observed outcomes.

Specific adenosine receptors are involved in the vascular responses seen, with different receptors modulating beneficial and detrimental effects. Vascular $\mathrm{A}_{2 \mathrm{~A}}$ and $\mathrm{A}_{2 \mathrm{~B}}$ receptors are down-regulated in allergic mice, and this was confirmed with the use of the specific receptor antagonists. To get a better insight into the role of $\mathrm{A}_{2 \mathrm{~A}}$ receptors on aortic tone, vascular responses to various adenosine analogs were studied in $\mathrm{A}_{2 \mathrm{~A}}$ receptor knock-out and wild type mice that were non-allergic.

In vitro aortic relaxation in $\mathrm{A}_{2 \mathrm{~A}} \mathrm{WT}$ mice was a biphasic response to NECA, a non-selective adenosine analog, while the response in $\mathrm{A}_{2 \mathrm{~A}} \mathrm{KO}$ tissue was concentrationdependent contraction. This indicated the possibility that the absence of $\mathrm{A}_{2 \mathrm{~A}}$ receptor as being responsible for contraction. $\mathrm{A}_{2 \mathrm{~A}} \mathrm{KO}$ mice also had lower endothelial relaxation than their wild-type counterparts, which suggested that relaxation through $A_{2 A}$ receptors occurred via an endothelial dependent mechanism. Use of the $\mathrm{A}_{1}$ antagonist (DPCPX) increased the relaxation in $\mathrm{A}_{2 \mathrm{~A}} \mathrm{WT}$ mice while the contraction observed in $\mathrm{A}_{2 \mathrm{~A}} \mathrm{KO}$ mice 
was reduced although relaxation was still absent. This again underscored a role for the $\mathrm{A}_{2 \mathrm{~A}}$ receptor in relaxation while confirming that the $\mathrm{A}_{1}$ receptor was responsible for adenosine-mediated contraction. These studies determined that the $\mathrm{A}_{2 \mathrm{~A}}$ receptor mediates vasorelaxation in the aorta in conjunction with the $\mathrm{A}_{2 \mathrm{~B}}$ receptor.

The next aim of the study was to determine the exact role of the $A_{1}$ receptor in the allergic model. The reason for focusing on the $A_{1}$ receptor came about from the initial study when it was found that the use of DPCPX (selective $\mathrm{A}_{1}$ receptor antagonist) restored aortic relaxation in allergic mice comparable to non-allergic controls. The $\mathrm{A}_{1}$ receptor was also found to be up-regulated in the aorta from allergic mice further subjected to adenosine aerosol.

Genetic knock-out mice were used to study and confirm the involvement of $\mathrm{A}_{1}$ receptor. Data showed that the allergic $\mathrm{A}_{1} \mathrm{WT}$ mice had lower adenosine-mediated aortic relaxation, significantly higher levels of inflammatory markers in the plasma and increased airway responsiveness. These outcomes were exacerbated in allergic $\mathrm{A}_{1} \mathrm{WT}$ mice that had received exogenous adenosine as a single aerosol inhalation. In contrast, no impairment in adenosine-mediated vascular responses were observed in $\mathrm{A}_{1} \mathrm{KO}$ (allergic and non-allergic controls) aortic tissue. There were significantly lower (or undetectable) levels of inflammatory markers and lower airway responsiveness to NECA in $\mathrm{A}_{1} \mathrm{KO}$ mice. In fact, there was no difference between allergic $A_{1} K O$ and control $A_{1} K O$ mice. These data implicate the $A_{1}$ receptor as having deleterious systemic and airway effects in allergic mice. The systemic effects appear to be the result of inflammation. However, the exact signaling mechanism(s) of the $A_{1}$ involved in translation of airway inflammation to the observed systemic outcomes is not known and remains to be studied. 


\section{Future Direction}

The next step in this model of asthma would be to define the adenosine receptor signaling mechanisms involved. Our preliminary data show that asthmatic mice have both lung as well as systemic inflammation. It is important to have a better understanding of this correlation and the possible signaling pathways involved. Based on the data in this dissertation that shows highest levels of IL-13 in allergic mice, and review of literature which has established a close relationship between IL-13 and adenosine in lung inflammation, the next focus could the potential role for this inflammatory cytokine as an intermediary signaling molecule, both in asthma and cardiovascular disease.

IL-13 is an important mediator in asthma and has been implicated in lung inflammation and airway remodeling. It is a product of mast cell degranulation and is also released from T-helper 2 (Th2) cells. Adenosine and IL-13 interact with each other in a positive feedback in studies done with asthmatic mice (Blackburn et al., 2003). These authors found that IL-13 caused a progressive increase in adenosine accumulation, inhibited the activity of adenosine deaminase, and augmented the expression of the $A_{1}$, $\mathrm{A}_{2 \mathrm{~B}}$, and $\mathrm{A}_{3}$ adenosine receptors. Their findings suggest that adenosine signaling contributes to and influences the severity of IL-13 induced tissue responses.

IL-13 signaling occurs through the Janus kinase (JAK)/signal transducer and activator of transcription (STAT) pathway. This cytokine acts on its receptor (via JAK-1) and leads to phosphorylation of STAT6, which induces the transcription of several genes including 5-lipoxygenase (LO). 5-LO, via the arachidonic acid pathway, produces inflammatory leukotrienes (LTs) which are very important mediators of IL-13 induced lung injury. Recent studies have also suggested a pro-atherosclerotic role for LTs with 
$\mathrm{LTB}_{4}$ acting as a potent leukocyte chemoattractant that amplifies inflammation at atherosclerotic sites (M.Back et al., 2005).

Other than LTs, studies in asthma have shown that IL-13 also induces vascular endothelial growth factor (VEGF) from human airway smooth muscle cells, mast cells, epithelial cells and macrophages (Faffe et al., 2006). In fact, IL-13 and VEGF act on each other in positive feedback loops. VEGF and VEGF receptor inhibitors reduce lung inflammation and airway hyper-reactivity in asthma (Faffe et al., 2006). This study also found that over expression of VEGF enhances Th2-mediated sensitization and inflammation. Studies involving human atherosclerosis have noted that VEGF is thought to play a pro-atherosclerotic role. VEGF is an angiogenic factor. It induces migration and proliferation of endothelial cells and enhances vascular permeability. It has been reported that human coronary atherosclerotic plaques were positive for VEGF mRNA but not so in normal arterial tissues (Inoue et al., 1998).

IL-13 and IL-4 act synergistically with TNF- $\alpha$ to increase eotaxin levels in the lungs. Eotaxin increases lung eosinophilia in asthma and is very important in amplification of eosinophilic inflammation. Though eosinophilia is considered to be a characteristic hallmark of asthmatic inflammation, eosinophils are not found in any significant amounts in atherosclerotic lesions. However, eotaxin may have a novel role in atherosclerosis that does not involve eosinophils. Haley et al. have reported that eotaxin and its receptor, CCR3, were overexpressed in the inflammatory infiltrate of human atheroma (Haley et al., 2000). CCR3 was predominantly expressed on macrophages and they suggest eotaxin may participate in mast cell activation or recruitment. 
Data in this dissertation show that systemic levels of IL-13 are increased significantly in allergic $\mathrm{A}_{1} \mathrm{WT}$ mice compared to non-asthmatic controls. Interestingly, allergic $\mathrm{A}_{1} \mathrm{KO}$ did not have any increase in IL-13, suggesting a role for the $\mathrm{A}_{1}$ receptor. The next step would be to determine if IL-13 does, in fact, have a role in vascular inflammation and the signaling mechanism involved. Ultimately, understanding the signaling pathway (s) involved would lead to uncovering of the translational mechanism (s) of lung inflammation to systemic effects in human asthma. 
Figure 6.1: Proposed pathway for IL-13 signaling effects in asthma

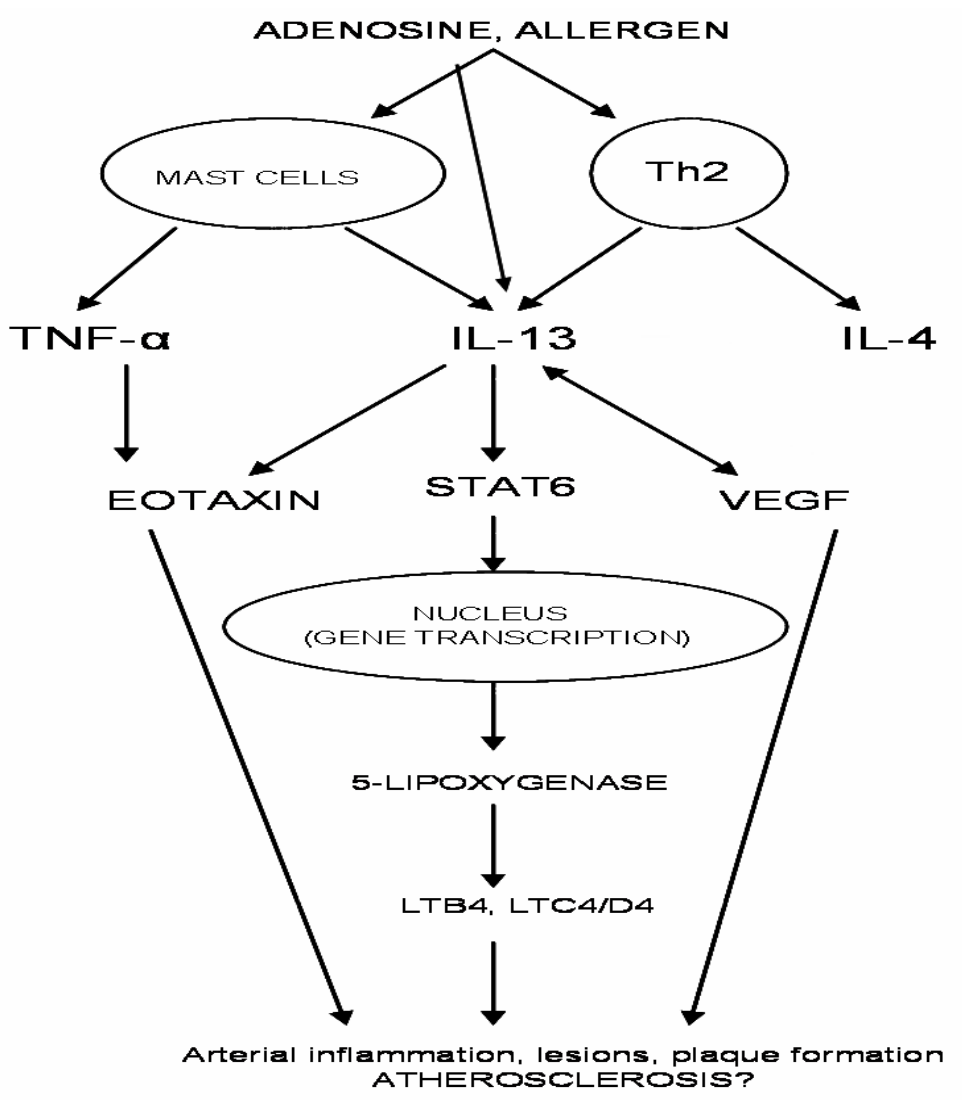




\section{PUBLICATIONS AND ABSTRACTS}

\section{MANUSCRIPTS}

Ponnoth DS, Nadeem A, Mustafa SJ "Adenosine-mediated alteration of vascular reactivity and inflammation in a murine model of asthma." Am J Physiol Heart Circ Physiol. 2008 May;294(5):H2158-65.

Nayeem MA, Poloyac SM, Falck JR, Zeldin DC, Ledent C, Ponnoth DS, Ansari HR, Mustafa SJ "Role of CYP epoxygenases in A2AAR-mediated relaxation using A2AARnull and wild-type mice.” Am J Physiol Heart Circ Physiol. 2008 Nov;295(5):H2068-78.

\section{ABSTRACTS}

"Adenosine mediated systemic effects in a murine model of allergic asthma." Dovenia Ponnoth, Ahmed Nadeem, R. Ray Morrison, S. Jamal Mustafa.

- Presented at the West Virginia University Health Sciences Center Research Day April, 2006

"Adenosine causes impaired vasorelaxation and systemic inflammation in a murine model of allergic asthma." Dovenia Ponnoth, Ahmed Nadeem, R. Ray Morrison, S. Jamal Mustafa.

- Presented at the U.S EPA/NHLBI/NIEHS sponsored meeting-The Role of Air Pollutants in Cardiovascular Disease, October 2006.

"The Role of Adenosine in Inflammation and Vascular Reactivity in a Murine model of Allergic Asthma." Dovenia Ponnoth, Ahmed Nadeem and S. Jamal Mustafa.

- Presented at the West Virginia University Health Sciences Center Research Day April, 2007

"Effects of adenosine on vascular reactivity and inflammation in a murine model of allergic asthma." Dovenia Ponnoth, Ahmed Nadeem, R. Ray Morrison, S. Jamal Mustafa.

- Presented at Experimental Biology, Washington DC, April 2007

"Absence of adenosine-induced relaxation in adenosine-KO mouse aorta: role of CYP 2C and CYP 4A." Mohammed A. Nayeem, John R. Falck, C. Ledent, Dovenia S. Ponnoth, Habib R. Ansari, Shilpa P. Sakhalkar, S Jamal Mustafa.

- Presented at Experimental Biology, Washington DC, April 2007 
“Adenosine $A_{2 A}$ receptor knock-out mice have impaired vasorelaxation and endothelial function.” Dovenia Ponnoth, C. Ledent and S. Jamal. Mustafa.

- Presented at Experimental Biology, San Diego CA, April 2008

" $A_{1}$ Adenosine Receptor Causes Inflammation and Impaired Vasorelaxation in a Murine Model of Asthma." D. Ponnoth, A. Nadeem, S.L. Tilley and S.Jamal.

- Presented at ATS (the American Thoracic Society), 2008-Toronto, Canada, May 2008.

"Decreased tracheal relaxation via $N A D P H$ oxidase activation in $A_{2 A} A R$ deficient allergic mice." Nadeem A, Dovenia PS , Batchelor T, Dey R, Ledent C, Mustafa SJ.

- Presented at ATS (the American Thoracic Society), 2008-Toronto, Canada May 2008. 


\section{REFERENCES}

Abebe W, Mustafa SJ (1998) A1 adenosine receptor-mediated Ins(1,4,5)P3 generation in allergic rabbit airway smooth muscle. Am J Physiol 275:L990-997.

Abebe W, Makujina SR, Mustafa SJ (1994) Adenosine receptor-mediated relaxation of porcine coronary artery in presence and absence of endothelium. Am J Physiol 266:H2018-2025.

Abraham WM, Delehunt JC, Yerger L, Marchette B (1983) Characterization of a late phase pulmonary response after antigen challenge in allergic sheep. Am Rev Respir Dis 128:839-844.

Ansari HR, Nadeem A, Tilley SL, Mustafa SJ (2007a) Involvement of COX-1 in A3 adenosine receptor-mediated contraction through endothelium in mice aorta. Am J Physiol Heart Circ Physiol 293:H3448-3455.

Ansari HR, Nadeem A, Talukder MA, Sakhalkar S, Mustafa SJ (2007b) Evidence for the involvement of nitric oxide in A2B receptor-mediated vasorelaxation of mouse aorta. Am J Physiol Heart Circ Physiol 292:H719-725.

Back M, Bu DX, Branstrom R, Sheikine Y, Yan ZQ, Hansson GK (2005) Leukotriene B4 signaling through NF-kappaB-dependent BLT1 receptors on vascular smooth muscle cells in atherosclerosis and intimal hyperplasia. Proc Natl Acad Sci U S A 102:17501-17506.

Bai N, Khazaei M, van Eeden SF, Laher I (2007) The pharmacology of particulate matter air pollution-induced cardiovascular dysfunction. Pharmacol Ther 113:16-29.

Bardenheuer H, Schrader J (1986) Supply-to-demand ratio for oxygen determines formation of adenosine by the heart. Am J Physiol 250:H173-180.

Belardinelli L, Linden J, Berne RM (1989) The cardiac effects of adenosine. Prog Cardiovasc Dis 32:73-97.

Belardinelli L, Shryock JC, Snowdy S, Zhang Y, Monopoli A, Lozza G, Ongini E, Olsson RA, Dennis DM (1998) The A2A adenosine receptor mediates coronary vasodilation. J Pharmacol Exp Ther 284:1066-1073.

Blackburn MR, Kellems RE (2005) Adenosine deaminase deficiency: metabolic basis of immune deficiency and pulmonary inflammation. Adv Immunol 86:1-41.

Blackburn MR, Volmer JB, Thrasher JL, Zhong H, Crosby JR, Lee JJ, Kellems RE (2000) Metabolic consequences of adenosine deaminase deficiency in mice are associated with defects in alveogenesis, pulmonary inflammation, and airway obstruction. J Exp Med 192:159-170. 
Blackburn MR, Lee CG, Young HW, Zhu Z, Chunn JL, Kang MJ, Banerjee SK, Elias JA (2003) Adenosine mediates IL-13-induced inflammation and remodeling in the lung and interacts in an IL-13-adenosine amplification pathway. J Clin Invest 112:332-344.

Braman SS (2006) The global burden of asthma. Chest 130:4S-12S.

Brown RA, Clarke GW, Ledbetter CL, Hurle MJ, Denyer JC, Simcock DE, Coote JE, Savage TJ, Murdoch RD, Page CP, Spina D, O'Connor BJ (2008) Elevated expression of adenosine A1 receptor in bronchial biopsy specimens from asthmatic subjects. Eur Respir J 31:311-319.

Brown RD, Thoren P, Steege A, Mrowka R, Sallstrom J, Skott O, Fredholm BB, Persson AE (2006) Influence of the adenosine A1 receptor on blood pressure regulation and renin release. Am J Physiol Regul Integr Comp Physiol 290:R1324-1329.

Busse WW, Lemanske RF, Jr. (2001) Asthma. N Engl J Med 344:350-362.

Cardaropoli S, Silvagno F, Morra E, Pescarmona GP, Todros T (2003) Infectious and inflammatory stimuli decrease endothelial nitric oxide synthase activity in vitro. $\mathrm{J}$ Hypertens 21:2103-2110.

Chunn JL, Young HW, Banerjee SK, Colasurdo GN, Blackburn MR (2001) Adenosinedependent airway inflammation and hyperresponsiveness in partially adenosine deaminase-deficient mice. J Immunol 167:4676-4685.

Cozzi E, Hazarika S, Stallings HW, 3rd, Cascio WE, Devlin RB, Lust RM, Wingard CJ, Van Scott MR (2006) Ultrafine particulate matter exposure augments ischemiareperfusion injury in mice. Am J Physiol Heart Circ Physiol 291:H894-903.

Cushley MJ, Tattersfield AE, Holgate ST (1983) Inhaled adenosine and guanosine on airway resistance in normal and asthmatic subjects. Br J Clin Pharmacol 15:161165.

Cushley MJ, Tattersfield AE, Holgate ST (1984) Adenosine-induced bronchoconstriction in asthma. Antagonism by inhaled theophylline. Am Rev Respir Dis 129:380-384.

de Weck AL, Mayer P, Stumper B, Schiessl B, Pickart L (1997) Dog allergy, a model for allergy genetics. Int Arch Allergy Immunol 113:55-57.

Deussen A, Lloyd HG, Schrader J (1989) Contribution of S-adenosylhomocysteine to cardiac adenosine formation. J Mol Cell Cardiol 21:773-782.

Drazen JM, Finn PW, De Sanctis GT (1999) Mouse models of airway responsiveness: physiological basis of observed outcomes and analysis of selected examples using these outcome indicators. Annu Rev Physiol 61:593-625. 
Drislane FW, Samuels MA, Kozakewich H, Schoen FJ, Strunk RC (1987) Myocardial contraction band lesions in patients with fatal asthma: possible neurocardiologic mechanisms. Am Rev Respir Dis 135:498-501.

Driver AG, Kukoly CA, Metzger WJ, Mustafa SJ (1991) Bronchial challenge with adenosine causes the release of serum neutrophil chemotactic factor in asthma. Am Rev Respir Dis 143:1002-1007.

Driver AG, Kukoly CA, Ali S, Mustafa SJ (1993) Adenosine in bronchoalveolar lavage fluid in asthma. Am Rev Respir Dis 148:91-97.

Evans DB, Schenden JA, Bristol JA (1982) Adenosine receptors mediating cardiac depression. Life Sci 31:2425-2432.

Faffe DS, Flynt L, Bourgeois K, Panettieri RA, Jr., Shore SA (2006) Interleukin-13 and interleukin-4 induce vascular endothelial growth factor release from airway smooth muscle cells: role of vascular endothelial growth factor genotype. Am J Respir Cell Mol Biol 34:213-218.

Fan M, Mustafa SJ (2002) Adenosine-mediated bronchoconstriction and lung inflammation in an allergic mouse model. Pulm Pharmacol Ther 15:147-155.

Fan M, Jamal Mustafa S (2006) Role of adenosine in airway inflammation in an allergic mouse model of asthma. Int Immunopharmacol 6:36-45.

Fan M, Qin W, Mustafa SJ (2003) Characterization of adenosine receptor(s) involved in adenosine-induced bronchoconstriction in an allergic mouse model. Am J Physiol Lung Cell Mol Physiol 284:L1012-1019.

Forsythe P, Ennis M (1999) Adenosine, mast cells and asthma. Inflamm Res 48:301-307.

Fozard JR, Hannon JP (2000) Species differences in adenosine receptor-mediated bronchoconstrictor responses. Clin Exp Allergy 30:1213-1220.

Fredholm BB (2007) Adenosine, an endogenous distress signal, modulates tissue damage and repair. Cell Death Differ 14:1315-1323.

Gan WQ, Man SF, Senthilselvan A, Sin DD (2004) Association between chronic obstructive pulmonary disease and systemic inflammation: a systematic review and a meta-analysis. Thorax 59:574-580.

Grbovic L, Radenkovic M (2003) Analysis of adenosine vascular effect in isolated rat aorta: possible role of $\mathrm{Na}+/ \mathrm{K}+-\mathrm{ATPase}$. Pharmacol Toxicol 92:265-271.

Grunig G, Warnock M, Wakil AE, Venkayya R, Brombacher F, Rennick DM, Sheppard D, Mohrs M, Donaldson DD, Locksley RM, Corry DB (1998) Requirement for IL-13 independently of IL-4 in experimental asthma. Science 282:2261-2263. 
Haley KJ, Lilly CM, Yang JH, Feng Y, Kennedy SP, Turi TG, Thompson JF, Sukhova GH, Libby P, Lee RT (2000) Overexpression of eotaxin and the CCR3 receptor in human atherosclerosis: using genomic technology to identify a potential novel pathway of vascular inflammation. Circulation 102:2185-2189.

Hamelmann E, Schwarze J, Takeda K, Oshiba A, Larsen GL, Irvin CG, Gelfand EW (1997) Noninvasive measurement of airway responsiveness in allergic mice using barometric plethysmography. Am J Respir Crit Care Med 156:766-775.

Hansen PB, Castrop H, Briggs J, Schnermann J (2003) Adenosine induces vasoconstriction through Gi-dependent activation of phospholipase $\mathrm{C}$ in isolated perfused afferent arterioles of mice. J Am Soc Nephrol 14:2457-2465.

Haynes J, Jr., Obiako B, Thompson WJ, Downey J (1995) Adenosine-induced vasodilation: receptor characterization in pulmonary circulation. Am J Physiol 268:H1862-1868.

Hazarika S (2005) Allergic inflammation in the airways enhances neutrophil recruitment to the myocardium and severity of ischemia-reperfusion

Hazarika S, Van Scott MR, Lust RM (2004) Myocardial ischemia-reperfusion injury is enhanced in a model of systemic allergy and asthma. Am J Physiol Heart Circ Physiol 286:H1720-1725.

Hazarika S, Van Scott MR, Lust RM (2007) Severity of myocardial injury following ischemia-reperfusion is increased in a mouse model of allergic asthma. Am J Physiol Heart Circ Physiol 292:H572-579.

Hussain T, Mustafa SJ (1995) Binding of A1 adenosine receptor ligand [3H]8cyclopentyl-1,3-dipropylxanthine in coronary smooth muscle. Circ Res 77:194198.

Huszar E, Vass G, Vizi E, Csoma Z, Barat E, Molnar Vilagos G, Herjavecz I, Horvath I (2002) Adenosine in exhaled breath condensate in healthy volunteers and in patients with asthma. Eur Respir J 20:1393-1398.

Inoue M, Itoh H, Ueda M, Naruko T, Kojima A, Komatsu R, Doi K, Ogawa Y, Tamura N, Takaya K, Igaki T, Yamashita J, Chun TH, Masatsugu K, Becker AE, Nakao K (1998) Vascular endothelial growth factor (VEGF) expression in human coronary atherosclerotic lesions: possible pathophysiological significance of VEGF in progression of atherosclerosis. Circulation 98:2108-2116.

Iribarren C, Tolstykh IV, Eisner MD (2004) Are patients with asthma at increased risk of coronary heart disease? Int J Epidemiol 33:743-748. 
Johnson JR, Wiley RE, Fattouh R, Swirski FK, Gajewska BU, Coyle AJ, GutierrezRamos JC, Ellis R, Inman MD, Jordana M (2004) Continuous exposure to house dust mite elicits chronic airway inflammation and structural remodeling. Am J Respir Crit Care Med 169:378-385.

Jousilahti P, Salomaa V, Hakala K, Rasi V, Vahtera E, Palosuo T (2002) The association of sensitive systemic inflammation markers with bronchial asthma. Ann Allergy Asthma Immunol 89:381-385.

Justice JP, Shibata Y, Sur S, Mustafa J, Fan M, Van Scott MR (2001) IL-10 gene knockout attenuates allergen-induced airway hyperresponsiveness in C57BL/6 mice. Am J Physiol Lung Cell Mol Physiol 280:L363-368.

Klotz KN, Hessling J, Hegler J, Owman C, Kull B, Fredholm BB, Lohse MJ (1998) Comparative pharmacology of human adenosine receptor subtypes characterization of stably transfected receptors in CHO cells. Naunyn Schmiedebergs Arch Pharmacol 357:1-9.

Knoflach M, Kiechl S, Mayr A, Willeit J, Poewe W, Wick G (2005) Allergic rhinitis, asthma, and atherosclerosis in the Bruneck and ARMY studies. Arch Intern Med 165:2521-2526.

Kumar RK, Herbert C, Yang M, Koskinen AM, McKenzie AN, Foster PS (2002) Role of interleukin-13 in eosinophil accumulation and airway remodelling in a mouse model of chronic asthma. Clin Exp Allergy 32:1104-1111.

Lewis CD, Hourani SM (1997) Involvement of functional antagonism in the effects of adenosine antagonists and L-NAME in the rat isolated heart. Gen Pharmacol 29:421-427.

Lewis CD, Hourani SM, Long CJ, Collis MG (1994) Characterization of adenosine receptors in the rat isolated aorta. Gen Pharmacol 25:1381-1387.

Li L, Roumeliotis N, Sawamura T, Renier G (2004) C-reactive protein enhances LOX-1 expression in human aortic endothelial cells: relevance of LOX-1 to C-reactive protein-induced endothelial dysfunction. Circ Res 95:877-883.

Liu S, Chihara K, Maeyama K (2005) The contribution of mast cells to the late-phase of allergic asthma in rats. Inflamm Res 54:221-228.

Livak KJ, Schmittgen TD (2001) Analysis of relative gene expression data using realtime quantitative PCR and the 2(-Delta Delta C(T)) Method. Methods 25:402408.

Lowry MH, McAllister BP, Jean JC, Brown LA, Hughey RP, Cruikshank WW, Amar S, Lucey EC, Braun K, Johnson P, Wight TN, Joyce-Brady M (2008) Lung lining 
fluid glutathione attenuates IL-13-induced asthma. Am J Respir Cell Mol Biol 38:509-516.

Mann JS, Renwick AG, Holgate ST (1986a) Release of adenosine and its metabolites from activated human leucocytes. Clin Sci (Lond) 70:461-468.

Mann JS, Holgate ST, Renwick AG, Cushley MJ (1986b) Airway effects of purine nucleosides and nucleotides and release with bronchial provocation in asthma. $\mathrm{J}$ Appl Physiol 61:1667-1676.

Martin PL, Ueeda M, Olsson RA (1993) 2-Phenylethoxy-9-methyladenine: an adenosine receptor antagonist that discriminates between A2 adenosine receptors in the aorta and the coronary vessels from the guinea pig. J Pharmacol Exp Ther 265:248-253.

McNamara N, Gallup M, Khong A, Sucher A, Maltseva I, Fahy J, Basbaum C (2004) Adenosine up-regulation of the mucin gene, MUC2, in asthma. Faseb J 18:17701772.

Mombouli JV, Vanhoutte PM (1999) Endothelial dysfunction: from physiology to therapy. J Mol Cell Cardiol 31:61-74.

Mubagwa K, Mullane K, Flameng W (1996) Role of adenosine in the heart and circulation. Cardiovasc Res 32:797-813.

Muccitelli RM, Tucker SS, Hay DW, Torphy TJ, Wasserman MA (1987) Is the guinea pig trachea a good in vitro model of human large and central airways? Comparison on leukotriene-, methacholine-, histamine- and antigen-induced contractions. J Pharmacol Exp Ther 243:467-473.

Mustafa S, Abebe W (1996) Coronary vasodilation by adenosine receptor subtypes and mechanism of action. Drug Dev Res 39:308-313.

Mustafa SJ, Askar AO (1985) Evidence suggesting an Ra-type adenosine receptor in bovine coronary arteries. J Pharmacol Exp Ther 232:49-56.

Mustafa SJ, Nadeem A, Fan M, Zhong H, Belardinelli L, Zeng D (2007) Effect of a specific and selective A(2B) adenosine receptor antagonist on adenosine agonist AMP and allergen-induced airway responsiveness and cellular influx in a mouse model of asthma. J Pharmacol Exp Ther 320:1246-1251.

Nadeem A, Mustafa SJ (2006) Adenosine receptor antagonists and asthma. Drug Disc Today: Therapeutic Strategies 3:269-275.

Nadeem A, Chhabra SK, Masood A, Raj HG (2003) Increased oxidative stress and altered levels of antioxidants in asthma. J Allergy Clin Immunol 111:72-78. 
Nadeem A, Fan M, Ansari HR, Ledent C, Jamal Mustafa S (2007) Enhanced airway reactivity and inflammation in A2A adenosine receptor-deficient allergic mice. Am J Physiol Lung Cell Mol Physiol 292:L1335-1344.

Newman WH, Becker BF, Heier M, Nees S, Gerlach E (1988) Endothelium-mediated coronary dilatation by adenosine does not depend on endothelial adenylate cyclase activation: studies in isolated guinea pig hearts. Pflugers Arch 413:1-7.

Nurkiewicz TR, Porter DW, Barger M, Castranova V, Boegehold MA (2004) Particulate matter exposure impairs systemic microvascular endothelium-dependent dilation. Environ Health Perspect 112:1299-1306.

Nurkiewicz TR, Porter DW, Barger M, Millecchia L, Rao KM, Marvar PJ, Hubbs AF, Castranova V, Boegehold MA (2006) Systemic microvascular dysfunction and inflammation after pulmonary particulate matter exposure. Environ Health Perspect 114:412-419.

Nyce JW, Metzger WJ (1997) DNA antisense therapy for asthma in an animal model. Nature 385:721-725.

O'Brien R, Ooi MA, Clarke AH, Thomas WR (1996) Immunologic responses following respiratory sensitization to house dust mite allergens in mice. Immunol Cell Biol 74:174-179.

Obiefuna PC, Batra VK, Nadeem A, Borron P, Wilson CN, Mustafa SJ (2005) A novel A1 adenosine receptor antagonist, L-97-1 [3-[2-(4-aminophenyl)-ethyl]-8-benzyl7-\{2-ethyl-(2-hydroxy-ethyl)-amino]- ethyl\}-1-propyl-3,7-dihydro-purine-2,6dione], reduces allergic responses to house dust mite in an allergic rabbit model of asthma. J Pharmacol Exp Ther 315:329-336.

Oldenburg PJ, Mustafa SJ (2005) Involvement of mast cells in adenosine-mediated bronchoconstriction and inflammation in an allergic mouse model. J Pharmacol Exp Ther 313:319-324.

Onufrak S, Abramson J, Vaccarino V (2007) Adult-onset asthma is associated with increased carotid atherosclerosis among women in the Atherosclerosis Risk in Communities (ARIC) study. Atherosclerosis 195:129-137.

Pearson TA, Mensah GA, Alexander RW, Anderson JL, Cannon RO, 3rd, Criqui M, Fadl YY, Fortmann SP, Hong Y, Myers GL, Rifai N, Smith SC, Jr., Taubert K, Tracy RP, Vinicor F (2003) Markers of inflammation and cardiovascular disease: application to clinical and public health practice: A statement for healthcare professionals from the Centers for Disease Control and Prevention and the American Heart Association. Circulation 107:499-511.

Pelleg A, Porter RS (1990) The pharmacology of adenosine. Pharmacotherapy 10:157174. 
Ponnoth DS, Nadeem A, Mustafa SJ (2008) Adenosine-mediated alteration of vascular reactivity and inflammation in a murine model of asthma. Am J Physiol Heart Circ Physiol 294:H2158-2165.

Prentice D, Boon K, Hourani S (2001) Relaxation of mouse isolated aorta to adenosine and its analogues does not involve adenosine $A(1), A(2)$ or $A(3)$ receptors. Eur $J$ Pharmacol 415:251-255.

Prentice DJ, Kelly MD, Ledent C, Hourani SM (2002) Relaxation of the mouse isolated aorta and carotid artery in response to adenosine analogues in geneticallymodified mice lacking the adenosine A(2A) receptor. Naunyn Schmiedebergs Arch Pharmacol 366:127-133.

Ralevic V, Burnstock G (1998) Receptors for purines and pyrimidines. Pharmacol Rev 50:413-492.

Ramgopal MV, Chitwood RW Jr, SJ. M (1988) Evidence for an $\mathrm{A}_{2 \mathrm{~A}}$ adenosine receptor in human coronary arteries. Eur J Pharmacol 151:483-486.

Rose Meyer RB, Harrison GJ, Headrick JP (2003) Enhanced adenosine A(2B) mediated coronary response in reserpinised rat heart. Naunyn Schmiedebergs Arch Pharmacol 367:266-273.

Rossi N, Churchill P, Ellis V, Amore B (1988) Mechanism of adenosine receptor-induced renal vasoconstriction in rats. Am J Physiol 255:H885-890.

Rubanyi G, Vanhoutte PM (1985) Endothelium-removal decreases relaxations of canine coronary arteries caused by beta-adrenergic agonists and adenosine. J Cardiovasc Pharmacol 7:139-144.

Salmon JE, Brogle N, Brownlie C, Edberg JC, Kimberly RP, Chen BX, Erlanger BF (1993) Human mononuclear phagocytes express adenosine A1 receptors. A novel mechanism for differential regulation of Fc gamma receptor function. J Immunol 151:2775-2785.

Schanen JG, Iribarren C, Shahar E, Punjabi NM, Rich SS, Sorlie PD, Folsom AR (2005) Asthma and incident cardiovascular disease: the Atherosclerosis Risk in Communities Study. Thorax 60:633-638.

Schwarze PE, Ovrevik J, Lag M, Refsnes M, Nafstad P, Hetland RB, Dybing E (2006) Particulate matter properties and health effects: consistency of epidemiological and toxicological studies. Hum Exp Toxicol 25:559-579.

Shepherd RK, Linden J, Duling BR (1996) Adenosine-induced vasoconstriction in vivo. Role of the mast cell and A3 adenosine receptor. Circ Res 78:627-634. 
Shryock JC, Belardinelli L (1997) Adenosine and adenosine receptors in the cardiovascular system: biochemistry, physiology, and pharmacology. Am J Cardiol 79:2-10.

Shryock JC, Snowdy S, Baraldi PG, Cacciari B, Spalluto G, Monopoli A, Ongini E, Baker SP, Belardinelli L (1998) A2A-adenosine receptor reserve for coronary vasodilation. Circulation 98:711-718.

Sidney S, Sorel M, Quesenberry CP, Jr., DeLuise C, Lanes S, Eisner MD (2005) COPD and incident cardiovascular disease hospitalizations and mortality: Kaiser Permanente Medical Care Program. Chest 128:2068-2075.

Sin DD, Man SF (2005) Chronic obstructive pulmonary disease as a risk factor for cardiovascular morbidity and mortality. Proc Am Thorac Soc 2:8-11.

Sparks HV, Jr., Bardenheuer H (1986) Regulation of adenosine formation by the heart. Circ Res 58:193-201.

Spicuzza L, Di Maria G, Polosa R (2006) Adenosine in the airways: implications and applications. Eur J Pharmacol 533:77-88.

Tabrizchi R, Bedi S (2001) Pharmacology of adenosine receptors in the vasculature. Pharmacol Ther 91:133-147.

Talukder MA, Morrison RR, Mustafa SJ (2002a) Comparison of the vascular effects of adenosine in isolated mouse heart and aorta. Am J Physiol Heart Circ Physiol 282:H49-57.

Talukder MA, Morrison RR, Jacobson MA, Jacobson KA, Ledent C, Mustafa SJ (2002b) Targeted deletion of adenosine $\mathrm{A}(3)$ receptors augments adenosine-induced coronary flow in isolated mouse heart. Am J Physiol Heart Circ Physiol 282:H2183-2189.

Tang L, Parker M, Fei Q, Loutzenhiser R (1999) Afferent arteriolar adenosine A2a receptors are coupled to KATP in in vitro perfused hydronephrotic rat kidney. Am J Physiol 277:F926-933.

Tawfik HE, Schnermann J, Oldenburg PJ, Mustafa SJ (2005) Role of A1 adenosine receptors in regulation of vascular tone. Am J Physiol Heart Circ Physiol 288:H1411-1416.

Teng B, Ledent C, Mustafa SJ (2008) Up-regulation of A 2B adenosine receptor in A 2A adenosine receptor knockout mouse coronary artery. J Mol Cell Cardiol 44:905914. 
Tockman MS, Pearson JD, Fleg JL, Metter EJ, Kao SY, Rampal KG, Cruise LJ, Fozard JL (1995) Rapid decline in FEV1. A new risk factor for coronary heart disease mortality. Am J Respir Crit Care Med 151:390-398.

Toren K, Lindholm NB (1996) Do patients with severe asthma run an increased risk from ischaemic heart disease? Int J Epidemiol 25:617-620.

Tousoulis D, Antoniades C, Koumallos N, Stefanadis C (2006) Pro-inflammatory cytokines in acute coronary syndromes: from bench to bedside. Cytokine Growth Factor Rev 17:225-233.

van den Berge M, Kerstjens HA, de Reus DM, Koeter GH, Kauffman HF, Postma DS (2004) Provocation with adenosine 5'-monophosphate, but not methacholine, induces sputum eosinophilia. Clin Exp Allergy 34:71-76.

Yen MH, Wu CC, Chiou WF (1988) Partially endothelium-dependent vasodilator effect of adenosine in rat aorta. Hypertension 11:514-518.

Yudkin JS, Stehouwer CD, Emeis JJ, Coppack SW (1999) C-reactive protein in healthy subjects: associations with obesity, insulin resistance, and endothelial dysfunction: a potential role for cytokines originating from adipose tissue? Arterioscler Thromb Vasc Biol 19:972-978.

Yudkin JS, Kumari M, Humphries SE, Mohamed-Ali V (2000) Inflammation, obesity, stress and coronary heart disease: is interleukin-6 the link? Atherosclerosis 148:209-214.

Zhong H, Chunn JL, Volmer JB, Fozard JR, Blackburn MR (2001) Adenosine-mediated mast cell degranulation in adenosine deaminase-deficient mice. J Pharmacol Exp Ther 298:433-440.

Zhong H, Shlykov SG, Molina JG, Sanborn BM, Jacobson MA, Tilley SL, Blackburn MR (2003) Activation of murine lung mast cells by the adenosine A3 receptor. J Immunol 171:338-345.

Zureik M, Kony S, Neukirch C, Courbon D, Leynaert B, Vervloet D, Ducimetiere P, Neukirch F (2004) Bronchial hyperresponsiveness to methacholine is associated with increased common carotid intima-media thickness in men. Arterioscler Thromb Vasc Biol 24:1098-1103. 


\section{APPENDIX A}

The relaxation response to NECA was calculated at two different concentrations of phenylephrine (PE) used to pre-contract tissues. This was done to determine the concentration of $\mathrm{PE}$ to be used for experiments. There was no difference in NECA mediated relaxation in tissues precontracted with $0.1 \mu \mathrm{M}$ and $1 \mu \mathrm{M}$ of $\mathrm{PE}$ respectively.

\section{NECA COMPARISON}

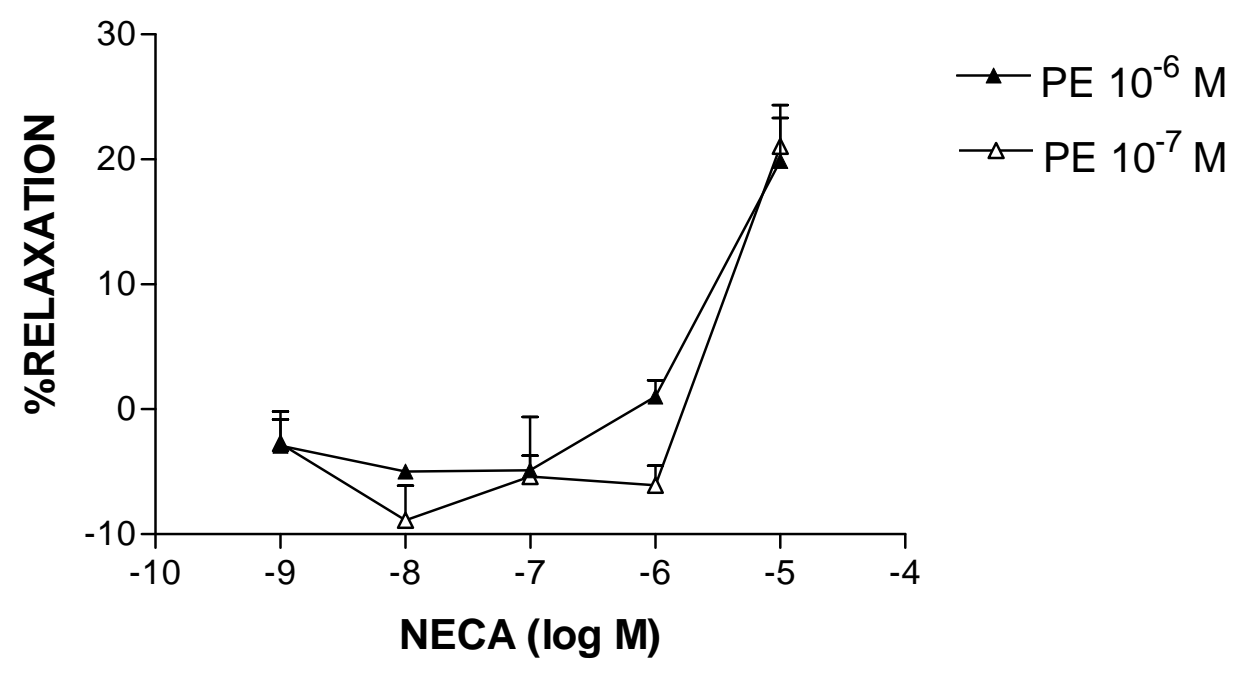


The relaxation response to adenosine was calculated at two different concentrations phenylephrine used to pre-contract tissues. This was done to determine the concentration of PE to be used for experiments. There was no difference in adenosine mediated relaxation in tissues precontracted with $0.1 \mu \mathrm{M}$ and $1 \mu \mathrm{M}$ of PE respectively.

\section{ADENOSINE COMPARISON}

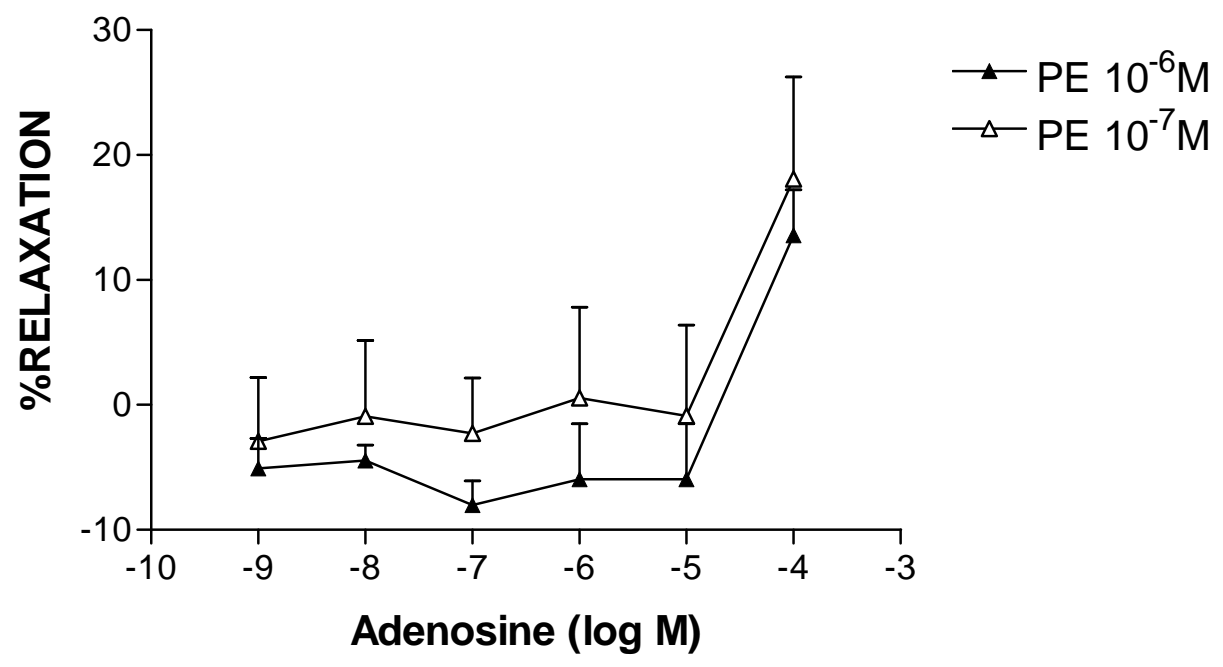


The endothelial response to acetylcholine was determined at two different concentrations phenylephrine (PE) used to pre-contract tissues. This was done to determine the concentration of PE to be used for experiments. There was no difference in adenosine mediated relaxation in tissues precontracted with $0.1 \mu \mathrm{M}$ and $1 \mu \mathrm{M}$ of PE respectively.

\section{EFFECT OF ACH}

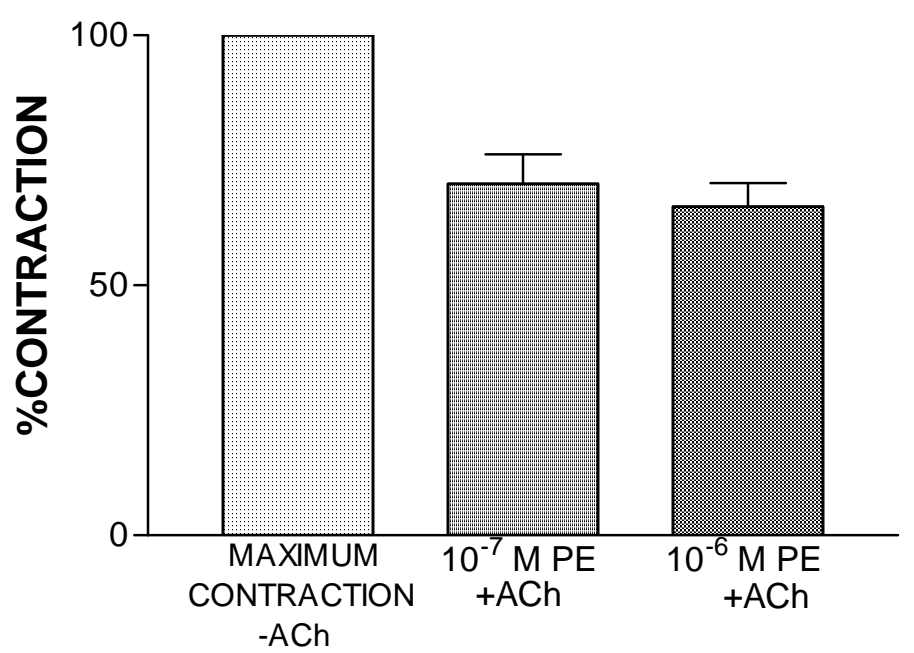

MAX CONTRACTION

$10^{-7} \mathrm{MPE}$

$10^{-6} \mathrm{PE}$

EFFECT PF ACH 


\section{APPENDIX B}

Preliminary experiments (airway responsiveness and vascular reactivity) were carried out with ovalbumin-sensitized and challenged $\mathrm{A}_{2 \mathrm{~A}} \mathrm{WT}$ and $\mathrm{A}_{2 \mathrm{~A}} \mathrm{KO}$ mice that had also received aerosolized adenosine challenge. $\mathrm{A}_{2 \mathrm{~A}} \mathrm{KO}$ mice had increased airway responsiveness as seen from the Penh data and reduced aortic relaxation to NECA compared to wild-type counterparts. However, adenosine mediated aortic vascular responses in naïve (non-allergic) mice were not known, which led to studying of vascular reactivity in $\mathrm{A}_{2 \mathrm{~A}} \mathrm{WT}$ and $\mathrm{A}_{2 \mathrm{~A}} \mathrm{KO}$ mice (Chapter 4)

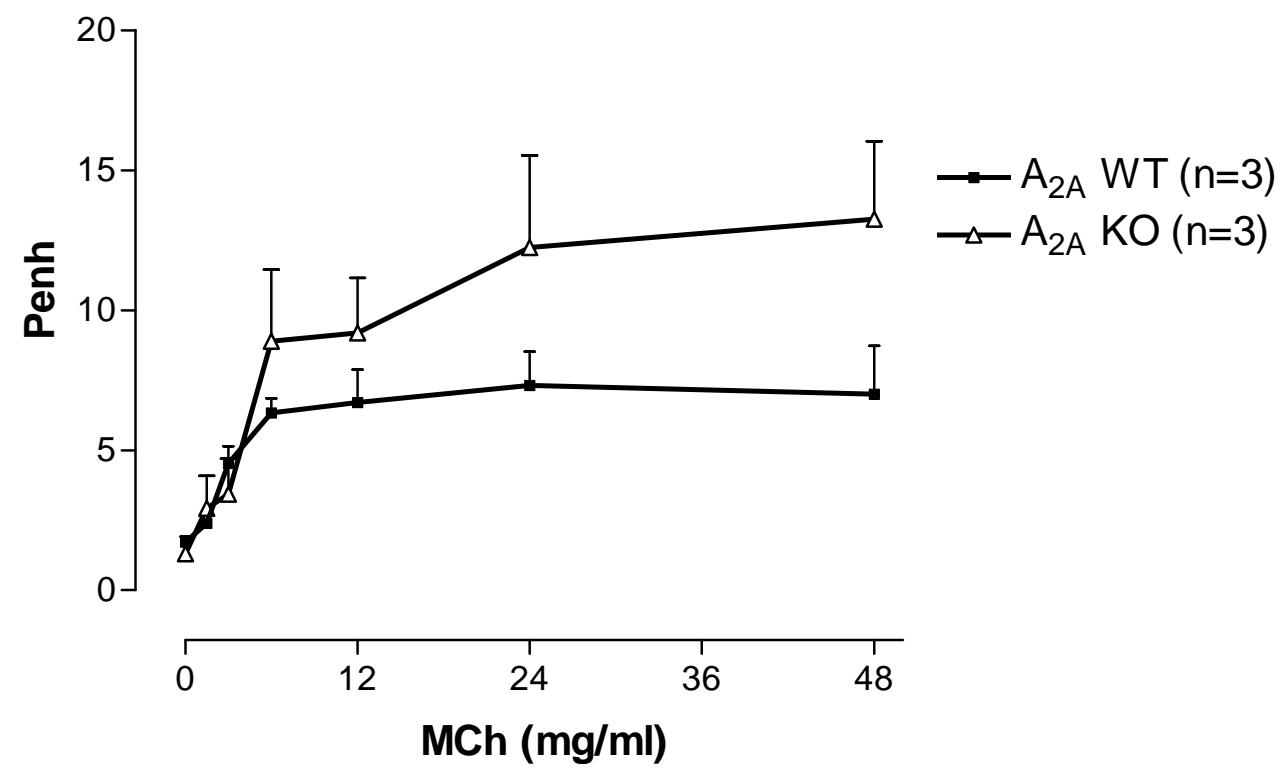

Airway responsiveness in $\mathrm{A}_{2 \mathrm{~A}} \mathrm{WT}$ and $\mathrm{A}_{2 \mathrm{~A}} \mathrm{KO} \mathrm{SEN}+\mathrm{AD}$ mice 


\section{$A_{2 A}$ SEN + AD}

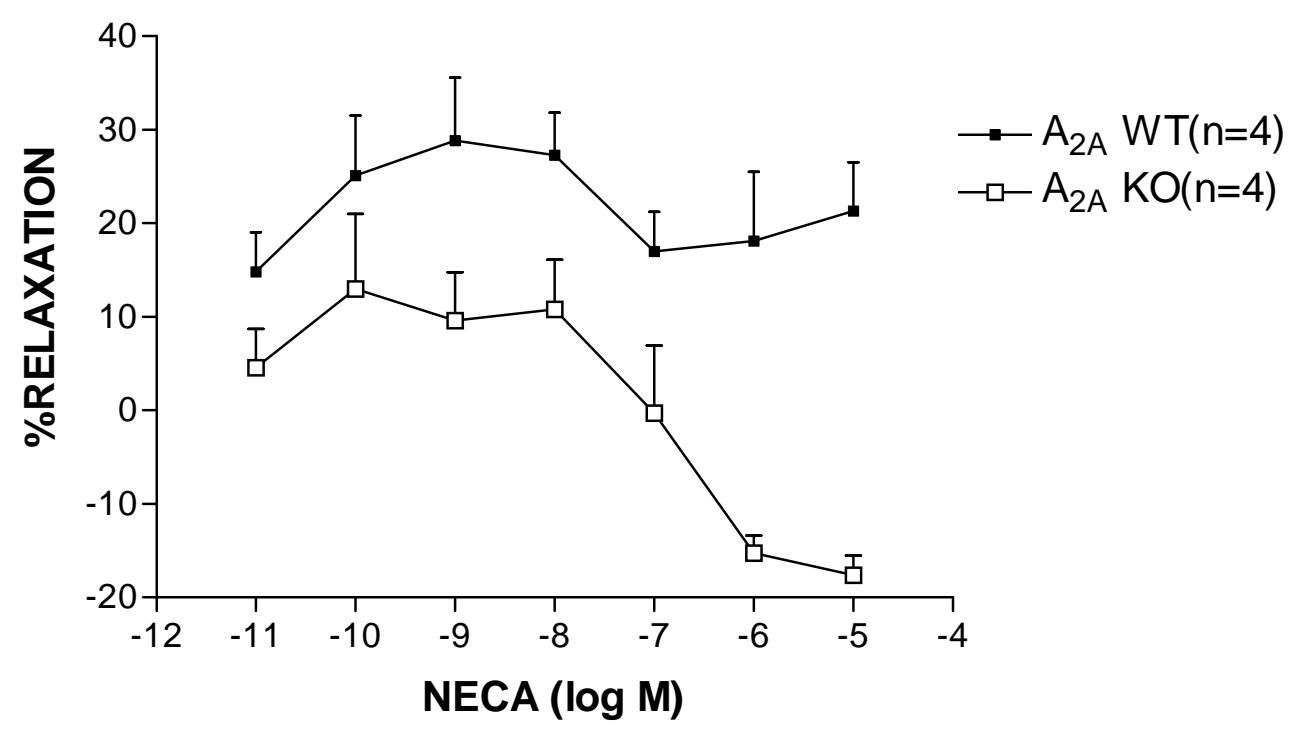

Aortic relaxation to NECA in $A_{2 A} W T$ and $A_{2 A} K O$ SEN+AD mice 


\section{APPENDIX C}

Level of inflammatory cytokines in bronchoalveolar lavage fluid was measured in control (CON), ragweed sensitized (SEN) and ragweed sensitized +aerosolized adenosine Balb/c mice to determine the difference in lung inflammation. Sensitized mice that had received the additional adenosine aerosol challenge had the highest level of inflammatory cytokines.

\section{IL-2 levels in BAL fluid from} Balb/c mice

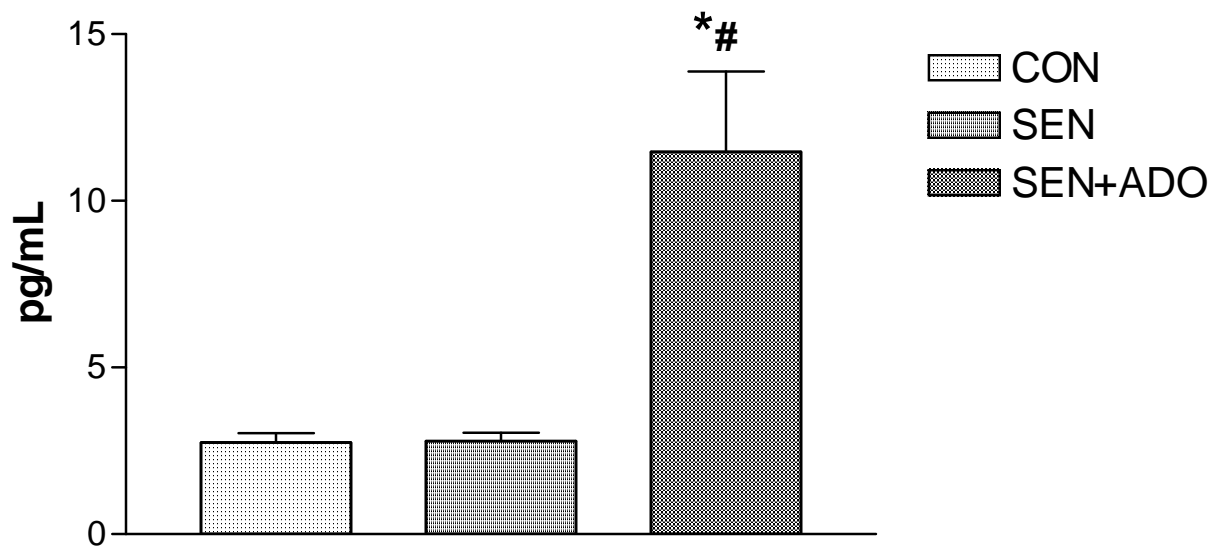

*P $<0.05$ compared to $\mathrm{CON}$; $\# \mathbf{P}<0.05$ compared to $\mathrm{SEN}$ 


\section{IL-5 levels in BAL fluid from} Balb/c mice

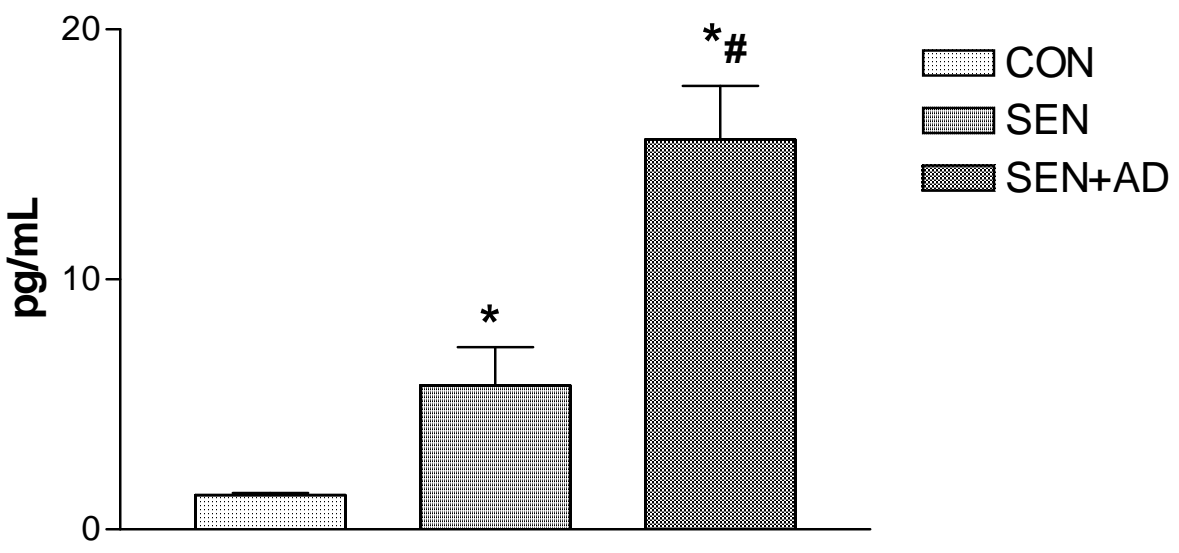

*P $<<0.05$ compared to $\mathrm{CON}$; $\# \mathbf{P}<0.05$ compared to $\mathrm{SEN}$ 


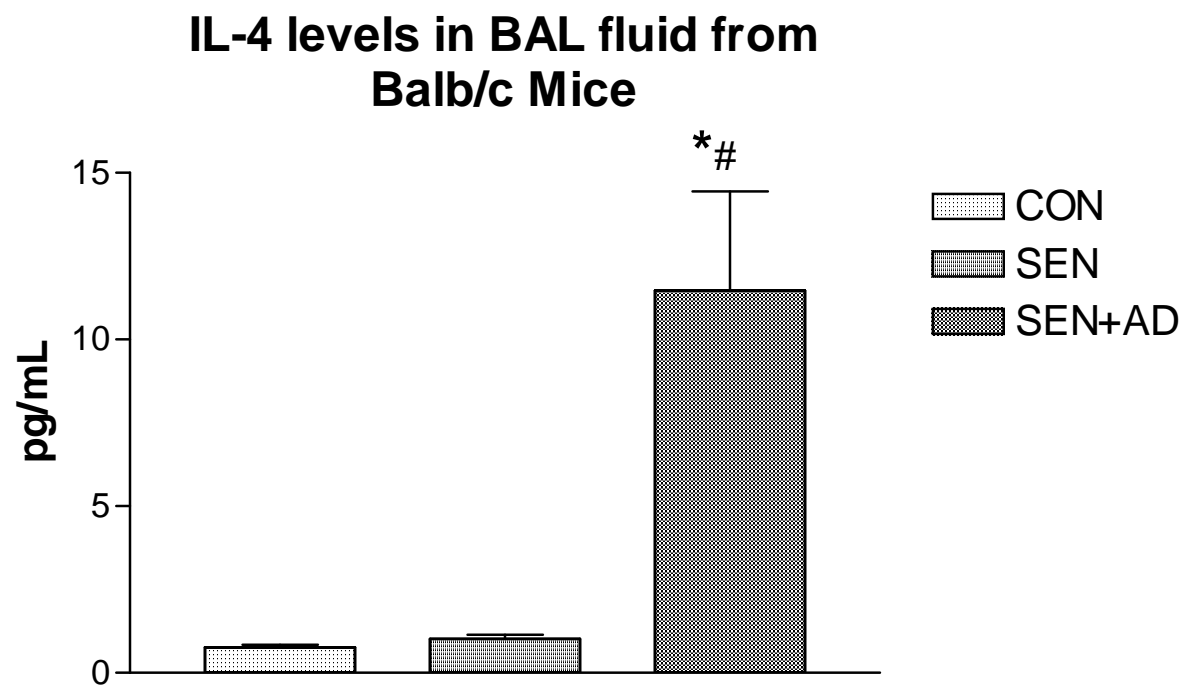

*P $<0.05$ compared to $\mathrm{CON}$; $\# \mathbf{P}<\mathbf{0 . 0 5}$ compared to $\mathrm{SEN}$ 
TNF- $\alpha$ levels in BAL fluid from Balb/c Mice

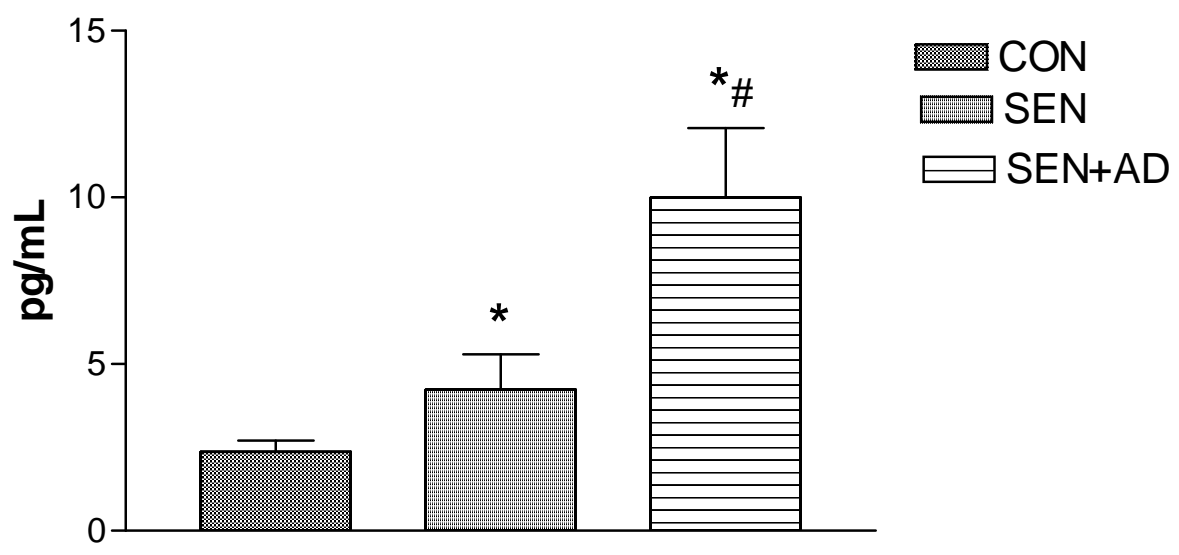

*P $<0.05$ compared to $\mathrm{CON}$; $\# \mathbf{P}<0.05$ compared to SEN 


\section{Biographical Sketch}

\begin{tabular}{|c|c|c|c|}
\hline $\begin{array}{l}\text { NAME (Last, First, Middle) } \\
\text { Ponnoth Dovenia S }\end{array}$ & \multicolumn{3}{|c|}{$\begin{array}{l}\text { POSITION TITLE } \\
\text { ORISE Fellow (National Institute for Occupational } \\
\text { Safety and Health) }\end{array}$} \\
\hline \multicolumn{4}{|l|}{ EDUCATION/TRAINING } \\
\hline INSTITUTION AND LOCATION & $\begin{array}{c}\text { DEGREE } \\
\text { (if applicable) }\end{array}$ & YEAR(s) & FIELD OF STUDY \\
\hline $\begin{array}{l}\text { Bharati Vidyapeeth’s College of Pharmacy, } \\
\text { Mumbai University India }\end{array}$ & $\mathrm{BS}$ & 1998-2002 & Pharmaceutical Sciences \\
\hline $\begin{array}{l}\text { East Carolina University (ECU), Greenville NC, } \\
\text { USA }\end{array}$ & & 2003-2005 & $\begin{array}{l}\text { Pharmacology \& } \\
\text { Toxicology }\end{array}$ \\
\hline $\begin{array}{l}\text { West Virginia University (WVU), Morgantown } \\
\text { WV,USA (transferred from ECU along with } \\
\text { mentor) }\end{array}$ & Ph. D. & $2005-2008$ & $\begin{array}{l}\text { Pharmaceutical and } \\
\text { Pharmacological Sciences }\end{array}$ \\
\hline & & & \\
\hline & & & \\
\hline
\end{tabular}

\section{A. Positions and Honors}

Graduate student ECU/WVU: August 2003-June 2006

Ph. D. candidate, WVU, Morgantown, WV: June 2006-August 2008

ORISE Fellow, NIOSH Morgantown, WV: September 2008-Present

\section{$\underline{\text { Awards }}$}

Graduate Student Travel Award: Awarded by the American Society for Pharmacology and Experimental Therapeutics (ASPET) at Experimental Biology, Washington DC, April 2007

The Sathu Somani Junior Scientist in Physiology Award: Awarded by the Association of Scientists of Indian origin in America (ASIOA) at its $25^{\text {th }}$ Annual Meeting, Washington DC, April 2007

Graduate Student Travel Award: Awarded by ASPET at Experimental Biology, San Diego, April 2008 


\section{Professional Memberships}

Student Member of ASPET: August 2006-Present

Student Member of ASIOA: January 2007-Present

\section{Teaching experience}

Facilitator: Medical Pharmacology small group conferences (active learning exercise) for medical students conducted by the Department of Physiology and Pharmacology, West Virginia University (March 2006-Present).

\section{B. Publications}

1. Ponnoth DS, Nadeem A, Mustafa SJ "Adenosine-mediated alteration of vascular reactivity and inflammation in a murine model of asthma." Am J Physiol Heart Circ Physiol. 2008 May;294(5):H2158-65.

2. Nayeem MA, Poloyac SM, Falck JR, Zeldin DC, Ledent C, Ponnoth DS, Ansari HR, Mustafa SJ "Role of CYP epoxygenases in A2AAR-mediated relaxation using A2AAR-null and wild-type mice." Am J Physiol Heart Circ Physiol. 2008 Nov;295(5):H2068-78.

\section{Manuscripts under review}

\section{High salt diet enhances mouse aortic relaxation through adenosine $A_{2 A}$ receptor via CYP epoxygenases}

Mohammed A. Nayeem, Dovenia S. Ponnoth, Matthew A. Boegehold, Darryl C. Zeldin, John R. Falck and S. Jamal Mustafa. [Submitted to the American Journal of Physiology (AJP) September 2008; reviewed and under revision]

\section{Manuscripts in preparation}

"Role of $A_{2 A}$ adenosine receptors in the regulation of vascular tone."

-Dovenia S. Ponnoth, Catherine Ledent, Maryam Sharifi, Kevin Roush, SJ Mustafa

"Evidence for the role of A1 adenosine receptors in inflammation and altered vascular reactivity in allergic mice."

- Dovenia S. Ponnoth, Ahmed Nadeem, Stephen L. Tilley, SJ Mustafa 


\section{E. ABSTRACTS}

"Adenosine mediated systemic effects in a murine model of allergic asthma." Dovenia Ponnoth, Ahmed Nadeem, R. Ray Morrison, S. Jamal Mustafa.

- Presented at the West Virginia University Health Sciences Center Research Day April, 2006

"Adenosine causes impaired vasorelaxation and systemic inflammation in a murine model of allergic asthma." Dovenia Ponnoth, Ahmed Nadeem, R. Ray Morrison, S. Jamal Mustafa.

- Presented at the U.S EPA/NHLBI/NIEHS sponsored meeting-The Role of Air Pollutants in Cardiovascular Disease, October 2006.

"The Role of Adenosine in Inflammation and Vascular Reactivity in a Murine model of Allergic Asthma." Dovenia Ponnoth, Ahmed Nadeem and S. Jamal Mustafa.

- Presented at the West Virginia University Health Sciences Center Research Day April, 2007

"Effects of adenosine on vascular reactivity and inflammation in a murine model of allergic asthma." Dovenia Ponnoth, Ahmed Nadeem, R. Ray Morrison, S. Jamal Mustafa.

- Presented at Experimental Biology, Washington DC, April 2007

"Absence of adenosine-induced relaxation in adenosine-KO mouse aorta: role of CYP 2C and CYP 4A." Mohammed A. Nayeem, John R. Falck, C. Ledent, Dovenia S. Ponnoth, Habib R. Ansari, Shilpa P. Sakhalkar, S Jamal Mustafa.

- Presented at Experimental Biology, Washington DC, April 2007

"Adenosine $A_{2 A}$ receptor knock-out mice have impaired vasorelaxation and endothelial function.” Dovenia Ponnoth, C. Ledent and S. Jamal. Mustafa.

- Presented at Experimental Biology, San Diego CA, April 2008

" $A_{1}$ Adenosine Receptor Causes Inflammation and Impaired Vasorelaxation in a Murine Model of Asthma.” D. Ponnoth, A. Nadeem, S.L. Tilley and S.Jamal.

- Presented at ATS (the American Thoracic Society), 2008-Toronto, Canada, May 2008.

"Decreased tracheal relaxation via NADPH oxidase activation in $A_{2 A} A R$ deficient allergic mice.” Nadeem A, Dovenia PS , Batchelor T, Dey R, Ledent C, Mustafa SJ.

- Presented at ATS (the American Thoracic Society), 2008-Toronto, Canada May 2008. 


\section{ABSTRACTS (to be presented)}

"Enhanced vascular relaxation through epoxygenase depends on ATP-sensitive $\mathrm{K}+$ channels via adenosine $\mathrm{A}_{2 \mathrm{~A}}$ receptor: Role of high salt diet”

Mohammed A. Nayeem, Matthew A. Boegehold, Dovenia S. Ponnoth, Darryl C. Zeldin, John R. Falck and S. Jamal Mustafa. Experimental Biology 2009, New Orleans. 